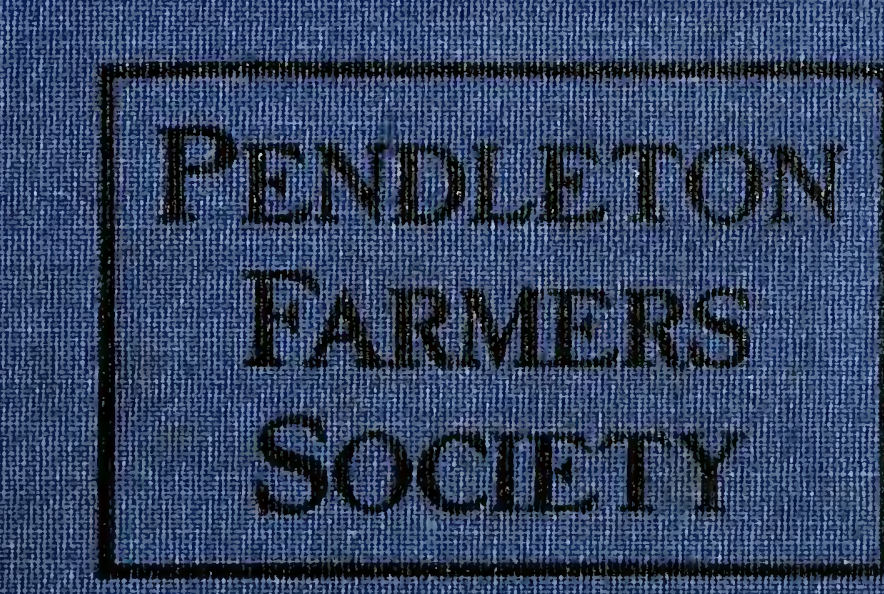




$$
\text { ฮ }
$$








\section{Pendleton Farmers'}

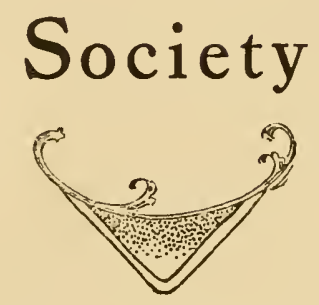

ATLANTA, GA.

FOOTE \& DAVIES CO.

1908 


\section{INDEX.}

1. Introduction and Dedication.

2. Pendleton Farmers' Society Property.

3. Roll of Members from 1820 to 1861.

4. Constitution as amended February, 1908.

5. Declaration and Petition for Charter.

6. Major George Seaburn and D. A. Smith.

\%. Governor Perry's Address.

8. Old Pendleton and Farmers' Society by J. C. S.

9. Reminiscences, by Maj. Benjamin Sloan.

10. Social Visiting Club, by H. E. Ravenel.

11. Thos. G. Clemson and the beginning of Clemson College.

12. Circular Letter, by Hon. W. H. Trescott.

13. Address by Dr. 'Tait Butler, February 13, 1908.

14. The Champion Corn Crops and Rice Crop.

15. Goober Jack, The Runaway Slave.

16. The Black Ghost of the Rocky Branch.

1\%. News Notes during the early days of the Society.

18. Old History of Society 1815-1820.

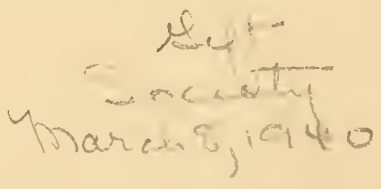




\section{THE PENDLETON FARMERS' SOCIETY.}

To present the history of this old society from its founding in 1815 and relate all that is of interest and value is an undertaking far beyond the ability of those to whom this important task is delegated. The motives, the ambitions and the incentives of its founders, could we but know them, would make classic agricultural literature. The theme is one worthy of a real historian and we regret that the task was not bestowed upon some one more worthy. The compilers of this history have been burdened with other duties and keenly feel the imperfections of their work, knowing that years of work would be required to adequately present the record of the society's members and the efforts and effects of the venerable Farmers' Society of Pendleton, S. C.

As an organization the society has always been that of an adult school for farmers-a vanguard in the march to the progressive in agriculture-a pioneer ever opening new and true methods in the first and greatest vocation of man. It has not taught the robbing of soil fertility and the exhaustion of nature given fertility for present gain and at the expense of future usefulness, but its efforts have been to teach the secrets of continued profitable tillage and not at the expense of the soil's future usefulness. The society has consistently stood for the conservation of the natural resources of the soil. In its early history the means of preventing surface washing, or dry land drainage, as it was then called, was a frequent topic for discussion. One of the members of the society once stated that the two great problems ever confronting him were, how to make good and useful citizens of his children and how to keep his soil from washing away. Upon the membership rolls of the society we find names prominent in peace and war, science and art. Many members of the society, and their descendants, are prominent among the distinguished in many States and many names are found upon the register of the Nation's great. These names are found among the leaders of men as statesmen, ministers, teachers, scientists, generals of industry, of army, of navy and wielders of the pen shaping the destiny of a nation. 
The earlier history of the society (1815-1820) is republished. The earlier events have also been well set forth in the last public address of Governor Perry, reminiscences by Maj. Benj. Sloan, James Seaborn and others.

We wish to thank the following gentlemen for rendering valnable assistance in the collection of data for this history: Col. Joseph N. Brown, Col. Robert Thompson, Rev. J. R. Earle, Dr. J. H. Maxwell, H. E. Ravenel, Chas. S. Reid, E. B. Benson, Ed Trescott and others whose names appear in the work.

C. L. NEWMANN,

J. C. Stribling,

Committee on History. 



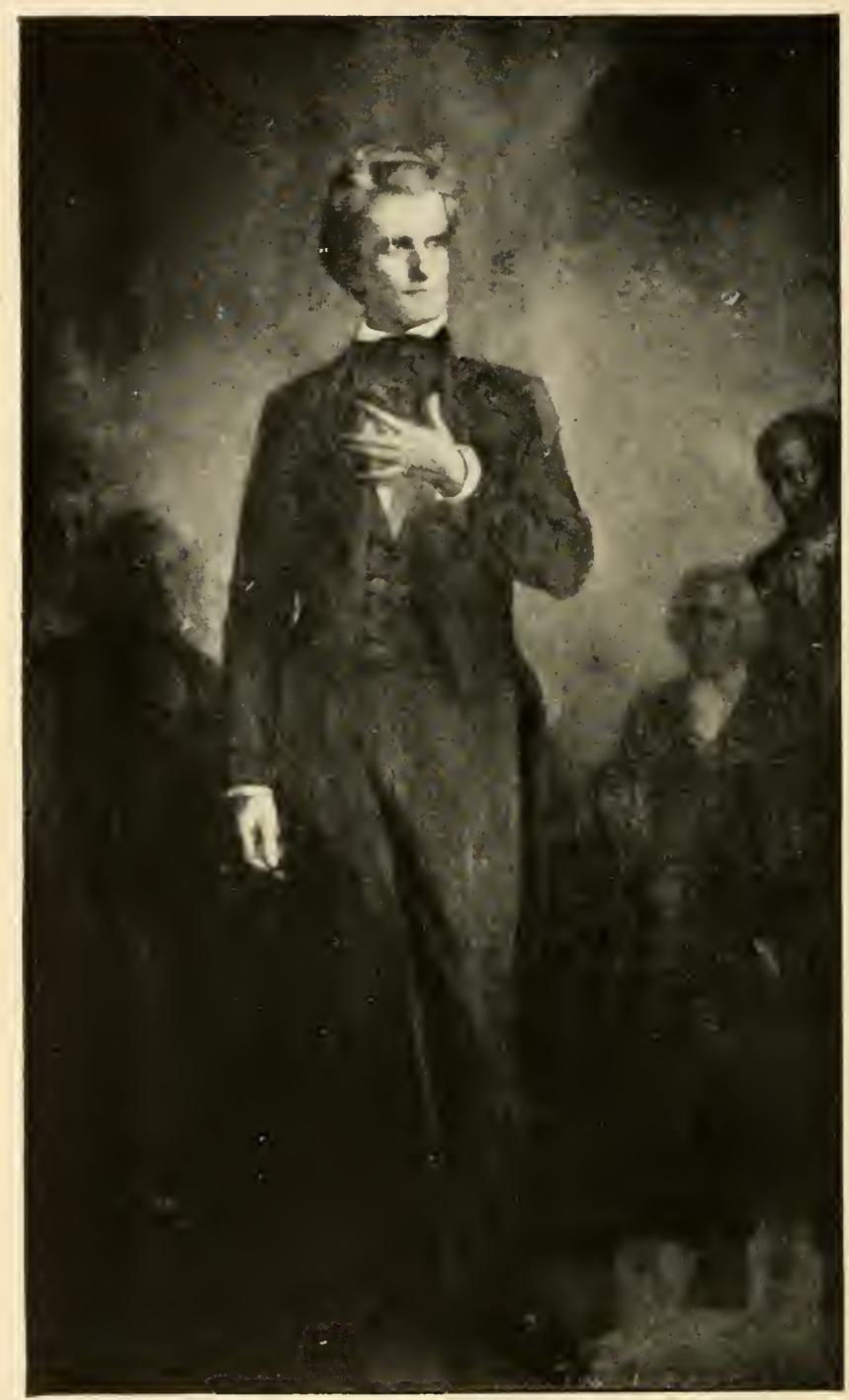

John C. Calhoury. 


\section{DEDICATION.}

To the memory of South Carolina's greatest statesman, John Caldwell Calhoun,- - a progressive farmer, eminent lawyer, and patriotic citizen. Born in Abbeville County, South Carolina, March 18, 1772, died in Washington, District of Columbia, Narch 31,1850 . Called by his people to occupy the highest political stations within their gift, from the State legislature, Congressional representative, United States Senator,-to the office of Secretary of War and the Vice-Presidency of the republic,- - he remained a leading and conspicuous figure in the annals of his country, to the close of his eventful and useful life. Leader of the war party against England in 1812, author of the tariff measure in 1816, burdened with tremendous responsibilities in other lines of his political life,- -he never disappointed the hopes, nor betrayed the confidence of his people. Faithful in every crisis, he has left us a legacy of unique patriotic virtue, of inspiring memories and imperishable hopes. To his memory, which South Carolina, with tens of thousands. of patriots beyond her limits will ever cherish, this volume is respectfully dedicated. 




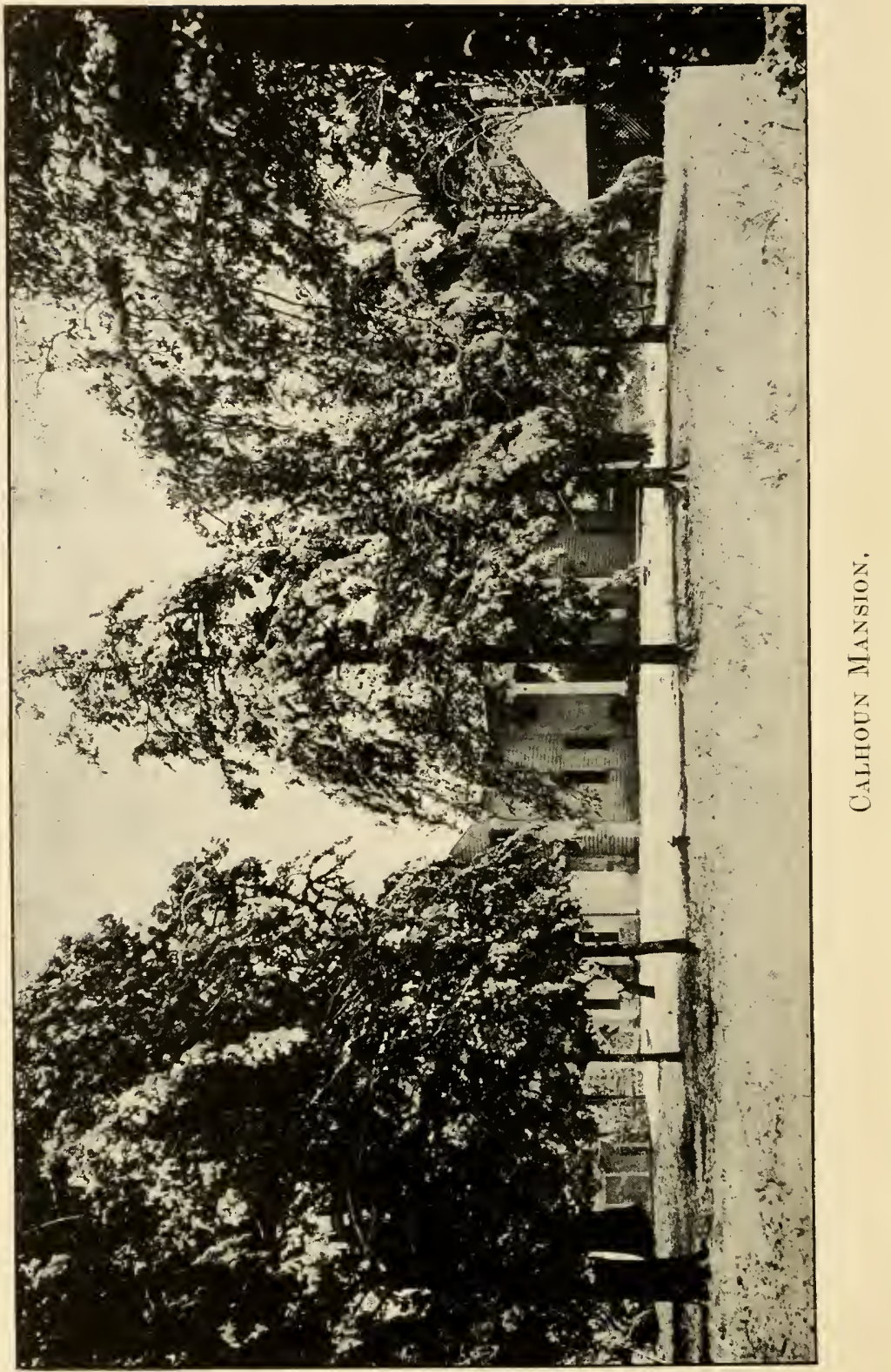




\section{FOREWORD.}

Reminiscence anent the wisdom and prophetic vision of John C. Calhoun. Sitting in the north porch of his colonial mansion about the year 1845, while engaged in conversation with Dr. Thomas Lewis and other friends: that if he stood in their places and desired to begin life with the growth of a populous city he would settle in Martha (now Atlanta), Georgia for the following reasons-that he believed that in the near future between here and the Blue Ridge Mountains a great railroad would be built from Washington to New Orleans, and that other systems of railways would climb over this chain of mountains through the gaps near Martha-now Atlanta, Georgia, going out from the rich valleys of the Ohio and westward in search of the Atlantic Coast. This conversation was related to the writer by the late Dr. Cherry of Seneca who was present when Mr. Calhoun made this prophetic remark which has since been written out in the unmistakable alphabet of accomplished facts.

J. C. S. 



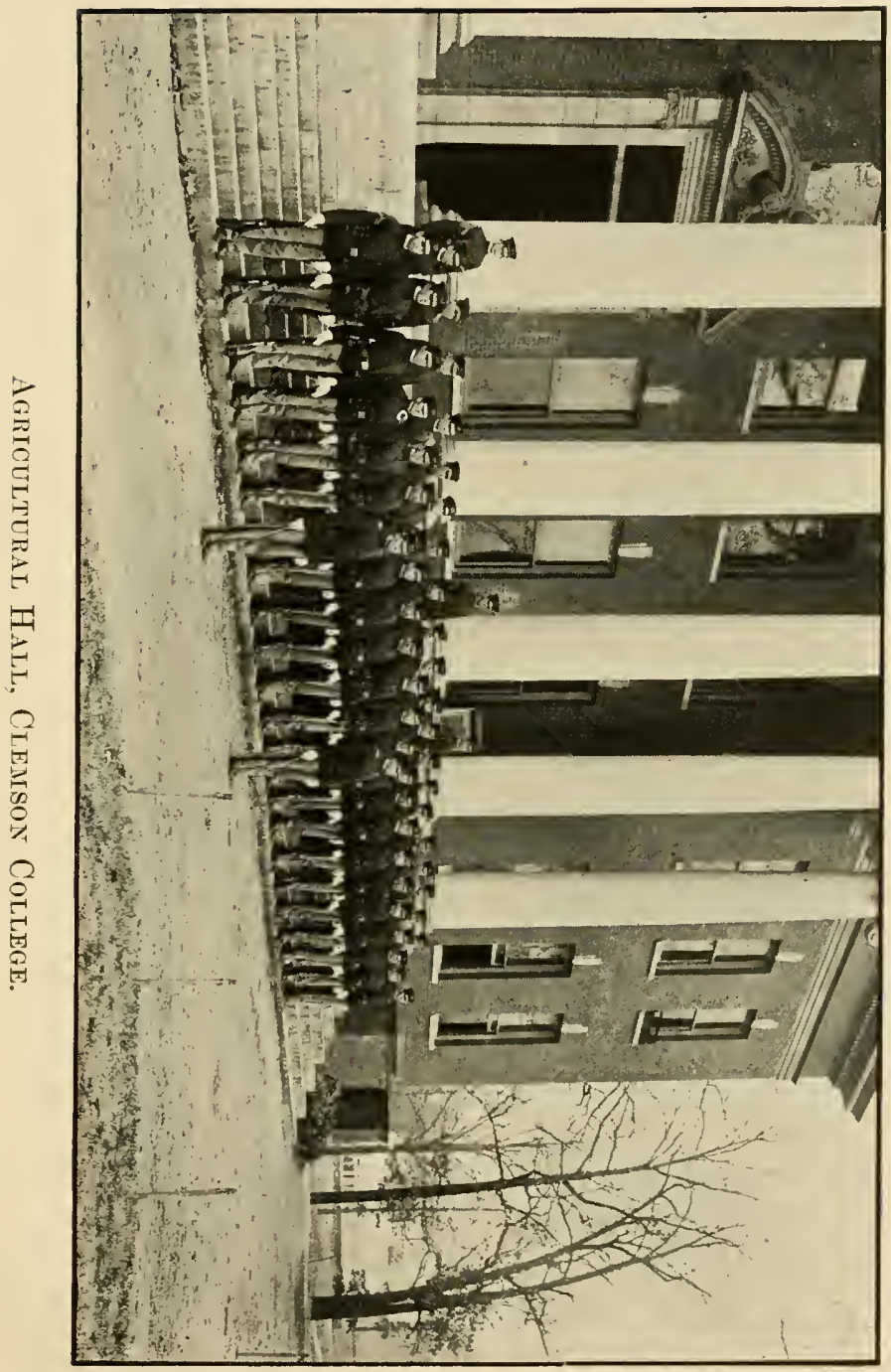



CHAPTER II. 


\section{PENDLETON FARMERS' SOCIETY PROPERTY.}

The following abstract from the Statutes of the State-kindly furnished the Society by Col. Joseph N. Brown of Andersonestablished the fact that the Society owned one-half acre lot prior to 1820 :

Anderson, S. C., April 2, $190 \%$

Mr. J. C. Stribling, Pendleton, S. C.

Dear Sir: I have been making diligent search of our Statutes, and can not find any disposition by the State, of the Pendleton Court House and jail. So far as the Statutes are concerned at least so far as printed, this property still belongs to the State. But no doubt the Pendleton Farmers' Society has acquired title in some way.

1. Deed on record is from Joseph V. Shanklin of one-half acre lot known as Farmers' Hall, on ......... Street giving no boundaries in consideration of one hundred dollars paid by Col. Thos. Pinckney, Jr., March 23, 1820. Recorded in Book P. Page 116 R. M. C. Anderson Dist. Witnesses Joseph P. Lewis and Sam'l. G. Earle.

2. Deed from Pendleton Farmers' Society of same lot to F. W. Symes, signed by Robt. Anderson. Dated June 9, 1832, consideration one hundred and eight dollars. Recorded in Book 5. Page 311 R. M. C.

Previous to the War between the States, it was not usual to pay for recording deeds until taken out of the Clerk's Office and this will account for Mr. Benson's paying it so long after it was made.

Very truly yours,

(Signed) Joseph N. Brown. 


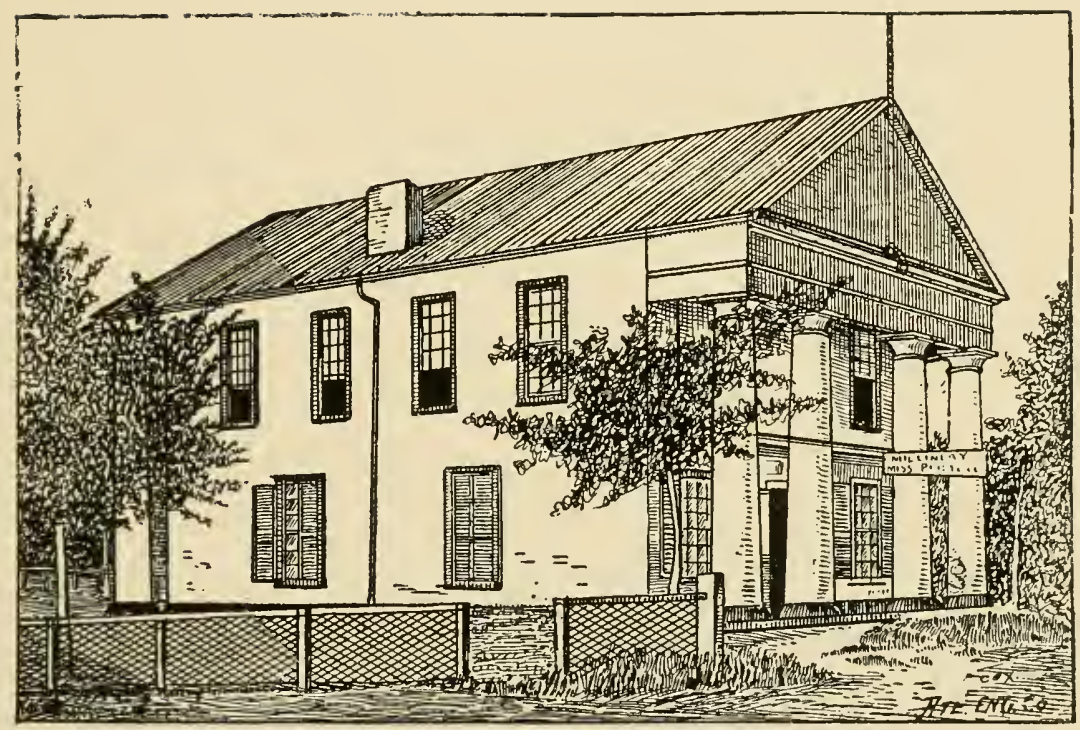

Picture of Pendeeton Farmers' Hall. 

The following notice published in the Pendleton Messenger, December 23,1818 , is evidence that the Society owned this onehalf acre lot during the year 1813 and they were then preparing to build a "Lodge" for their use by popular subscription of material.

\section{NOTICE.}

"The members of the Pendleton Farmers' Society, who have subscribed for the building of their "Lodge," are required to have the materials subscribed, at the Society's lot on the first of January next; or as soon as possible. These persons who have subscribed particular articles, will please apply to Major E. Sharp to know the quantity to be furnished." December 21, 1818.

\section{PENDLETON DISTRICT DIVIDED.}

Act 20, Dec. 1826.

Statutes at large, vol. Page 289-290.

"Col. J. C. Kilpatrick, Major Lewis and Thos. Garvin, commissioners, with two surveyors to mark the line. James Harrison, R. B. Norris, M. Gambrell, J. C. Griffin, Wm. Stewart to select plans for court-house. Anderson District-Andrew Hamilton, R. H. Briggs, J. C. Kilpatrick, Wm. Bearut and Jabes Jones for Pickens Dist. Col. Jacob Ben. Ion, President Senate, J. B. O'Neall, speaker of House of Representatives-That the court-house for Pendleton now contracted to be built be abandoned and after satisfying such damages as the contractor may suffer from the loss of his contract which shall be determined by commissioners appointed to run the line aforesaid, the balance of the money appropriated be equally divided between the commissioners aforesaid, one-half to be at the disposal of the commissioners for building their respective court-houses."

\section{DATE WHEN PRESENT BRICK BUILDING WAS COMMENCED.}

The Act of the Legislature in 1826 dividing Pendleton District into Anderson and Pickens Districts and also suspending work on the new court-house shows that work on this building 
was then in progress and it is said by some of the older citizens that this wall was built up about to the window sills by Pendleton District, and that the balance of the wall was built by the Pendleton Farmers' Society before October 9, 1829 at which date the treasurer's book shows that hall was renterl to W. Clayton \& Co. for exhibition purposes and that $\$ 10$ rent was received for the same. October 13, 1834 Dr. Gibbs paid $\$ 104$ for four years' rent of room rented March, 1829.

That the Society was owner of the brick hall October 10, 1828 - an item of entry on treasurer's book of that date for $\$ 6.00$ being paid to "John Adams for work done on Farmers" Old Hall,"-is evidence that the Society then owned a new hall at that date.

In the year 1843, it is stated by John Hall-the son of Calvin Hall the mason-and others, that Calvin Hall built the four tall, brick columns at ends of the brick Farmers' Hall and extended the roof over them as it now stands, and made other changes inside of hall.

That Thos. M. Sloan had the hall built, note item on Treasurer's book dated September 30, 1844 where " $\$ 266.81$ eash paid T. M. Sloan balance of $\$ 400$ dne for building hall."

Treasurer's book show that bonds were paid at intervals to ' $T$. M. Sloan and B. F. Sloan from 1845 up to 1853 to the amount of $\$ 515.8 \%$ "for building house" which no doubt was a debt for building the present hall which is verified by a notice by George Seaburn, editor, in the Farmer \& Planter for December, 1853, viz.

\section{The Pẹndeton Farmers Society.}

"We are pleased to announce to the members of this oldest Society in the State which has for a few years past been in a state of torpidity than otherwise that there is evident signs of a waking up and recovery from its lethargy." "It is now out of debt in which it has been involved in consequence of building a hall (the best probably in the State) for its use and in future we trust to be able to offer more liberal premiums than have been given."

The foregoing statements from our records set aside the legend 
that the present Farmers' Hall was built and used as a courthouse by Pendleton District and that John C. Calhoun made speeches in court in this building. But that John C. Calhoun no doubt did make many speeches in this hall before the Farmers' Society and perhaps on other occasions too, we here submit the following notice copied from the Pendleton Messenger, October 11, 1839.

"At the anniversary meeting of the Pendleton Farmers' Society, being the first Thursday in October, the following gentlemen were elected officers to the Society for the ensuing year:"

Hon. John C. Calhoun, President.

Dr. James Stuart, Vice-President.

J. V. Shanklin, Second Vice-President.

Dr. F. W. Symmes, Corresponding Secretary and Librarian.

E. B. Benson, Rec. Secretary and Treasurer.

Treasurer's book shows that John C. Calhoun, notwithstanding the fact that he was an honorary member-paid his annual dues the same as other members every year until 1830, when he paid $\$ 18.00$ for nine years. 


\section{OLD SUN DIAL.}

In conversation with Mr. Harleston, who makes the within aftidavit he told me that when Col. Huger was leaving his Long House place near Pendleton, he was present and heard a discussion between his Father, Col. Edward Harleston and Col. Hnger as to what disposition should be made of the Sun Dial that stood in his garden and that the conclusion was to present it to Pendleton Farmers Society, which to his own knowledge was done.

Mr. B. Frank Sloan formerly of Pendleton told me that he distinctly remembered seeing Maj. Creo. Seaborn (who was a surveyor) with his compass placing the Sun Dial in the Public Square at Pendleton.

JaMes Seaborn.

Walhalla, S. C., May 31, $190 \%$.

State of South Carolina,

County of Charleston.

Personally appeared before me Mr. Jno. Harleston of Charleston, State and County above named and made oath to the following effect:

I am a grandson of Col. Frank K. Huger and have a distinct recollection of my Grandfather, the said Col. Frank K. Huger, making a gift of the Sun Dial that stands in the Public Square at Pendleton, S. C., to the old Pendleton Farmers' Society. My recollection of the circumstance is very clear and I further believe that Maj. George Seaborn, then President of the said Society received the Sm Dial for the use and benefit of the Society.

Sworn to and subscribed hefore me this the 10th day of May, $190 \%$.

(Sig.) TAMEs SEABORN, (Sig.) JNo. HARLESTON. Notary Public, S. C. 


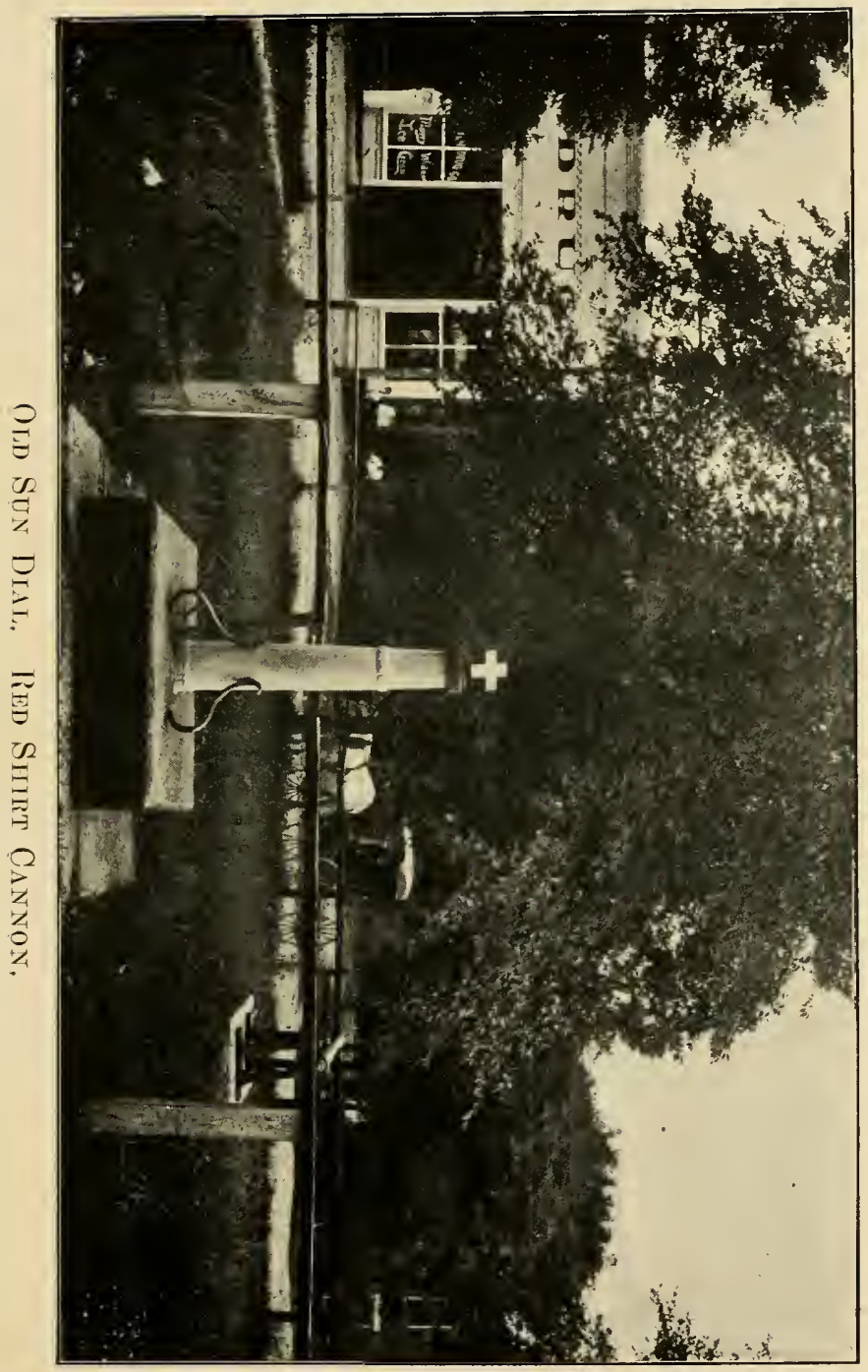





\section{PENDLETON FARMERS' SOCIETY.}

\section{Anderson Mail, February 10, 1908.}

On February 13, the Pendleton Farmers' Society will have a meeting of more than usual interest. The executive committee at a recent meeting perfected arrangements for an open session on the above date and all are invited to be present, and especially the ladies. An interesting program is arranged. Among the speakers will be Mr. Tait Butler, veterinarian and director of Farmers' Institute for North Carolina, and Dr. S. A. Knapp, chief officer in charge of the Demonstrated Farm work carried on by the National Department of Agriculture. Both of these distinguished gentlemen are entertaining and gifted orators and a rare treat is in store for those who attend this meeting.

The Pendleton Farmers' Society holds an important position in the history of the State and in the history of the United States. It is one of the oldest organizations of its kind in America and is in fact as well as in name a farmers' society. Its organization dates back to 1815 . On its membership rolls, preserved in the old hall owned by the Society, are to be found the names of John C. Calhoun, and Thomas G. Clemson, both of whom took an active interest and participated in the work of the Society. In a paper read by Mr. Clemson in 1867 the advantages of the establishment of the College such as Clemson College were strongly set forth and from this germ of thought was developed the Clemson idea that finally culminated after Mr. Clemson's death and through the execution of his will, in the location and establishment of the College that bears his name, and has more students taking the full agricultural course than any institution in America, if not in the world. One of the 
chiest members of the Society was not far wrong when he remarked that "the Pendleton Farmers' Society is the mother of Clemson Agricultural College."

This Society owns its handsome colonial hall in the center of Pendleton. This building was erected in the early part of the last century. The membership of this Society through its ninety-three years of existence has been large, and descendants from the members are scattered from South Carolina to the Pacific Coast.

A little less than a year ago, it was decided that the history of the Society shonld be written and this important undertaking was assigned to Col. J. C. Stribling who has collected a large amount of material in addition to that embraced in the minutes and record of the Society. This history is to be published by the Society and Col. Stribling will be thankful for any historical notes be:aring in any way upon the past of the Society or any of its nembers. Col. Stribling may be commmnicated with at Pendleton, S. C.

The executive committee of the Society is anxious to secure pictures for hanging in their hall and requests friends of the Society to make such contributions. Particularly is it desirous that pictures of old members be secured for the hall as well as rural pictures of either interest or value. Acknowledgments of such donation will be made and they will be carefully preserved in the history hall.

C. L. NewMan. 
CHAPTER III. 


\section{PENDLETON FARMERS' SOCIETY.}

List of the Members from 1820 to 1861-Are Your Ancestors ON IT?

Robt. Anderson,

Dr. Wm. Anderson,

G. T. Anderson,

Rev. J. B. Adger,

Capt. J. E. Adger,

E. B. Benson,

John P. Benson,

J. G. Baker,

Armstead, Burt,

B. Batchelor,

O. R. Broyles,

G. T. Barnette,

Aaron Boggs,

J. N. Boggs,

John C. Calhoun,

John E. Calhoun,

Wm. Clark,

Samuel Cherry, William Carter, A. P. Calhoun, John R. Cherry, Colin Campbell, Archibald Campbell, T. Herbert Cown,

E. D. Cherry,

J. IV. Crawford,

Ransom Calhoun,

W. R. Calhomn,

Rev. A. H. Cornish,

H. E. Campbell,

F. M. Cobb,

J. W. Cobh,

James Nickson,
Thos. Dickson,

Dr. R. E. Elliott,

Geo. E. F. Foster,

John B. Ferrell,

John S. Foster,

Alfred Fuller,

Col. Jos. Grisham,

James C. Griffin,

J. D. Genlord,

Col. Israel Gillerson,

Dr. A. S. Gibbes,

W. H. D. Gaillari,

Charley Gaillard,

Gen. F. N. Garvin,

G. G. Gilman,

Edw. Harleston,

Col. John Finnter,

Col. Francis K. Huger,

Tavid K. Hamilton,

Wm. Hubbard,

John G. Hunter,

Thomas Harrison,

Bentley Hasel,

Alfred Huger,

Joseph Hillhouse,

John Humes,

Ezekiel Harris,

Tames Hamilton,

Paul Hamilton,

Tohn Hastie,

J. W. Harrison,

Col. W. A. Hayne,

John Holmes, 
Wm. L. Jenkins,

W. R. Jones,

Jolin C. Kilpatrick,

Robt. Lewis,

Jesse P. I Lewis,

W. C. Livingston,

J. 0. Lewis,

A. F. Lewis,

T. L. Lewis,

J. T. Latta,

John Maxwell,

Jas. L. McCann,

Isaac Murphree,

R. A. Maxwell,

S. E. Maxwell,

C. B. Moses, John C. Miller,

M. S. McCrary,

H. C. Miller,

Jesse Martin,

M. P. Maxwell,

Warren Martin,

Martin McKay,

J. C. Miller,

S. E. Mayes,

John McPhail,

Jephtha Nortnn.

John L. North,

Jesse W. Norris,

Tohn S. Newton,

Thos. Pinckney,

C. C. Pinckney,

Thos. J. Pickens,

William Poe,

A. C. Pickens,

Richard S. Porcher,

John Robinson,

Willis Robinson,

A. IV. Ross,

Carver Randal.
H. E. Ravenel,

Jolnn Raleter,

Thomas Reid,

James Stewart,

David Sloan,

John M. Sloan,

Benjamin Sloan,

Benjamin Smith,

Wm. C. Smith,

J. V. Shanklin,

F. IV. Symmes,

Wm. Sloan,

Elam Sharp,

Thos. M. Sloan,

B. F. Sloan,

Wm. Steele,

Robt. Simpson,

George Seaborn,

Archibald Seabrook,

John T. Sloan,

R. F. Simpson,

J. R. Shelor,

J. D. Smith,

William Simpson,

Edward Symmes,

J. I. Simpson,

David S. Taylor,

D. R. Towers,

E. A. Tate,

John Verner,

Samuel Verner,

Wrm. VanTyck,

Joseph Whitner,

Samuel Warren,

Jacob Warley,

J. T. Whitfield,

Thos. Warley,

J. D. Wright,

Greenberry Whitten,

S. M. Wilson, 


\section{NEW LIFE IN THE OLD FARMERS' SOCIETY.}

At a meeting held in Farmers Hall, Pendleton, S. C. on February 14, 1906, the members names mentioned below were all the surviving members on the roll who at this date began work to build up a larger membership by publishing the following notice:

The regular quarterly meeting of the Old Pendleton Farmers' Society will be held in their hall at Pendleton, S. C., Thursday, 14th of February, next, at $10 \mathrm{a} . \mathrm{m}$. As most all of its members are now old men it is important that every old member of this Society put forth a special effort to get up a lot of young farmers to join the Society at this meeting, so as to perpetuate the life and history of the Society. List of members: J. C. Stribling, vice-president; S. L. Eskew, secretary; executive committee, J. C. Stribling, B. Harris, H. S. Trescott, J. W. Simpson, M. M. Hunter, E. G. Evins, Jr., O. A. Bowen, J. E. Lewis, J. J. Sitton, R. E. Sloan, R. W. Simpson, Jas. T. Hunter, J. N. Hunter, J. M. Pickens, Dr. P. H. E. Sloan, C. Hankle, Dr. W. W. Watkins, Samuel McCrary, E. Hopkins, J. J. Lewis, Warren J. Martin, Dr. J. H. Maxwell, B. Frank Sloan, C. W. Young, J. A. Price, S. C. George, H. E. Ravenel, Daniel Ravenel, F. J. Pelzer, A. T. Smyth, Dr. T. J. Pickens, B. F. Crayton, Julius Shanklin, Col. M. P. Tribble, B. C. Crawford are all the living members to date.

Members of Pendleton Farmers' Society in 1908, when this history was written: President, J. C. Stribling, Pendleton, S. C.; Vice-President, B. Harris, Pendleton, S C.; Secretary and Treasurer, J. B. Harris, Pendleton, S. C.; Corresponding Secretary, Prof. C. L. Newman, Clemson College; Librarian, B. H. Sadler, Pendleton, S. C.; Chaplain, Rev. K. G. Findley, Clemson College.

Executive Committee: B. Harris, H. C. Summers, J. N. Harper, John L. Long, A. N. Richardson. 


\section{MEMBERS IN 1908.}

Dr. P. H. E. Sloan .................. Pendieton, S. C. E. G. Evans $\ldots \ldots \ldots \ldots \ldots \ldots \ldots \ldots$. Pendleton, S. C.

S. M. McCrary $\ldots \ldots \ldots \ldots \ldots \ldots \ldots$ Pendleton, S. C.

J. M. Pickens $\ldots \ldots \ldots \ldots \ldots \ldots \ldots$. . Pendleton, S. C.

J. W. Simpson $\ldots \ldots \ldots \ldots \ldots \ldots \ldots$. Pendleton, S. C.

J. T. Hunter . . . . . . . . . . . . . . . . Pendleton, S.

M. M. Hunter $\ldots \ldots \ldots \ldots \ldots \ldots \ldots \ldots \ldots \ldots \ldots \ldots \ldots \ldots \ldots$ Pendleton, S. C.

M. B. Richardson .................. Pendleton, S. C.

H. S. Trescott $\ldots \ldots \ldots \ldots \ldots \ldots \ldots \ldots$ Pendleton, S. C.

A. T. Smythe $\ldots \ldots \ldots \ldots \ldots \ldots \ldots \ldots$. . . . .

S. L. Eskew $\ldots \ldots \ldots \ldots \ldots \ldots \ldots \ldots$ Pendleton, S. C.

J. N. Hunter $\ldots \ldots \ldots \ldots \ldots \ldots \ldots \ldots \ldots$. Pendleton, S. C.

J. M. Sitton ...................... Pendleton, S. C.

F. B. Martin $\ldots \ldots \ldots \ldots \ldots \ldots \ldots \ldots \ldots$ Pendleton, S. C.

A. H. Mitchell $\ldots \ldots \ldots \ldots \ldots \ldots \ldots$. Pendleton, S. C.

T. W. Stevens $\ldots \ldots \ldots \ldots \ldots \ldots \ldots \ldots \ldots$ Pendleton, S. C.

H. P. Sitton $\ldots \ldots \ldots \ldots \ldots \ldots \ldots \ldots$ Pendleton, S. C.

H. C. Summers, Jr. ................. Pendleton, S. C.

T. R. McCrary $\ldots \ldots \ldots \ldots \ldots \ldots \ldots \ldots$ Pendleton, S. C.

J. A. Barnett ...................... Pendleton, S. C.

B. F. McMfurtry $\ldots \ldots \ldots \ldots \ldots \ldots \ldots$. Pendleton, S. C.

J. D. Smith $\ldots \ldots \ldots \ldots \ldots \ldots \ldots \ldots$. Pendleton, S. C.

W. G. Wilson $\ldots \ldots \ldots \ldots \ldots \ldots$........... Pendleton, S. C.

W. L. Ward $\ldots \ldots \ldots \ldots \ldots \ldots \ldots \ldots$. Pendleton, S. C.

J. W. Palmer .................... Pendleton, S. C.

J. W. Suttles $\ldots \ldots \ldots \ldots \ldots \ldots \ldots \ldots$. Pendleton, S. C.

Dr. R. B. Day $\ldots \ldots \ldots \ldots \ldots \ldots \ldots$. Pendleton, S. C.

Dr. W. K. Sharp $\ldots \ldots \ldots \ldots \ldots \ldots \ldots$. Pendleton, S. C.

Thos. P. Hobson $\ldots \ldots \ldots \ldots \ldots \ldots \ldots$. . . Pendleton, S. C.

W. W. Smith $\ldots \ldots \ldots \ldots \ldots \ldots \ldots \ldots$ Pendleton, S. C.

Dr. A. A. Cox $\ldots \ldots \ldots \ldots \ldots \ldots \ldots$. . . Pendleton, S. C.

W. E. Hall $\ldots \ldots \ldots \ldots \ldots \ldots \ldots \ldots \ldots$. Pendleton, S. C.

W. B. Aull $\ldots \ldots \ldots \ldots \ldots \ldots \ldots \ldots$. . Pendleton, S. C.

Ben Aull ........................

J. A. Shanklin .................... Pendleton, S. C.

M. M. Hunter . . . . . . . . . . . . . . Pendleton, S. C. 
Dr. L. A. Klein ............... Clemson College, S. C.

S. H. Provast ............... Clemson College, S. C.

F. H. Clinkscales .............. Clemson College, S. C.

B. C. Hard ................. Clemson College, S. C.

A. Schilletter ................ Clemson College, S. C.

Dr. A. N. Redfern ..............Clemson College, S. C.

J. P. Lewis ..................... Clemson College, S. C.

W. D. Garrison, Jr. ............ Clemson College, S. C.

W. A. Boggs ............. Clemson College, S. C.

K. E. Ravenel ................. Spartanburg, S. C.

J. D. McElroy .....................

J. R. Vandiver ....................

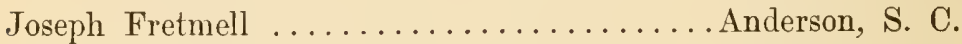

Col. J. N. Brown ................ Anderson, S. C.

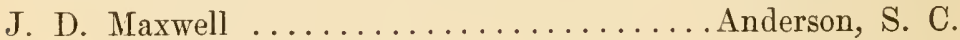

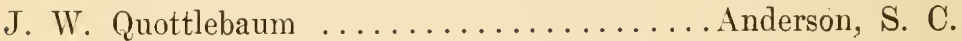

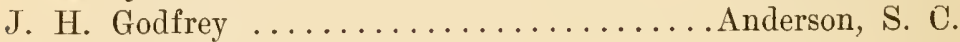

T. T. Wakefield ...................

J. C. Watkins .....................

R. W. Shelor . . . . . . . .

Jas. W. Shelor .................Walhalla, S. C.

J. W. Holleman . ................. Walhalla, S. C.

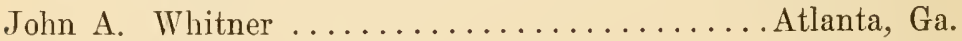

Chas. F. Whitner .......................

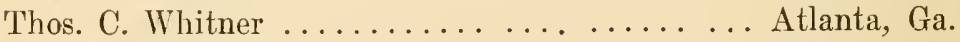

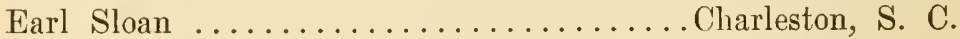

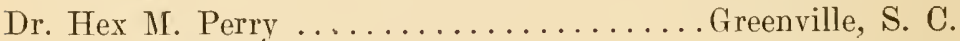

M. W. E. Seabrook . . . . . . . . . . . Savannah, Ga.

E. H. Shanklin . . . . . . . . . . . . . Easley, S. C.

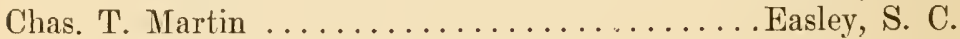

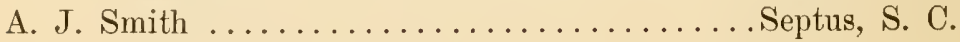

Complimentary Members.

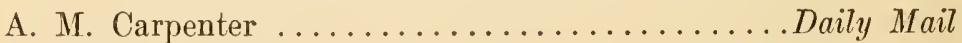

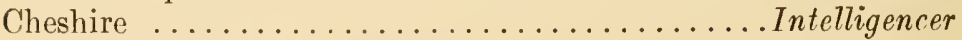

J. F. Cluckscales .................. Intelligencer

Rev. W. H. Mills .................. Pendleton, S. C. 
Honorary Members.

Col. R. A. Thompson ...............Walhalla, S. C. Maj. Benj. Śloan ................... University, S. C.

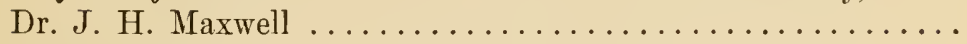

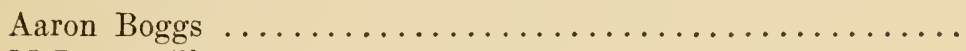
McIvor Williamson

Z. G. Deake 

CHAPTER IV. 
CONSTITUTION, AS AMENDED AND APPROVED FEBRUARY, $190 \%$.

Article 1. The Society shall be known and styled The Pendleton Farmers' Society.

ArT. 2. The object of the Society shall be the promotion and improvement of agricultural stock and mechanics.

Arт. 3. A President, Vice-President, Secretary and Treasurer, Corresponding Secretary and Librarian, shall be elected annually by a majority of the members present at the anniversary of the Society, on the second Thursday in November, in each year, the persons elected to continue in office for one year or until a new election takes place. In case of vacancy, by death, resignation or otherwise, the same may be supplied by a new election, made at any stated meeting of the Society, the person elected to serve the remainder of the year.

ART. 4. At all the meetings of the Society, the President shall exercise all the duties of that office, all motions shall be addressed to him, and on all questions he shall cancel and declare the votes. He shall have power to call public meetings by giving public notice of six days. In his absence the VicePresident shall exercise the same power. A quorum for the transaction of business shall consist of seren members.

ART. 5. The Secretary and Treasurer shall keep the books and papers of the Society, and the assets regularly stated at the meeting previous to the anniversary. He shall produce his assets fairly stated, books and papers, and deliver them to his successor on the anniversary or to the order of the Society. 
ART. 6. The Corresponding Secretary and Librarian shall have in charge all letters addressed to the Society and answer the same with the counsel of the executive committee, which letters and answers he shall keep regularly filed. He shall also take charge of the Society library and keep the same filed safely in the Farmers' Hall. He may loan out books to the members, keeping a list of the books and persons loaned to. No books to be kept ont longer than from one stated meeting to the next.

ART. 7. The stated meetings of the Society shall be on the second Thursday in Febrinary, May, August and November.

ART. 8. The members of the Society shall be distinguished into regular, honorary, and contributing members. Regular members shall consist of persons residing within the State. All members of agricultural societies in other States and countries with whom this Society shall correspond, and all persons of this State and other countries and States who shall be elected for the purpose shall be honorary members, and are merely invited to assist in the meetings whenever they may come within the country. Strangers desiring to be auditors may be introduced by a regular member. Honorary contributing members are of the description hereafter mentioned. Every citizen contributing and paying into the hands of the Treasurer a sum not less than ten dollars may be elected agreeably to the rules, an honorary member, without regard to place of residence. Those who thus laudably enable this Society to extend its usefulness and promote its objects are invited to assist in its meetings.

ART. 9. New members whether honorary or resident may be elected at any stated meeting, being proposed by a member.

ART. 10. For the purpose of defraying the necessary expenses of the Society for............. and prizes, books on agriculture, improved instruments, on farming and other important objects, every member shall pay annually into the hands of the Treasurer on the anniversary the sum of one dollar. At the close of which said meeting the Treasurer-elect shall...... 
before the Society a list of the members specifying who has and who has not paid their contributions. No part of the Society funds shall be disposed of except by the executive committee, at a stated meeting.

ART. 11. New rules and alterations may be passed at any stated meeting of the Society by a vote of two-thirds of the members present.

ART. 12. That an executive committee of five (5) members of the Society be appointed by the President on the day of election of officers. 


\section{RULES AND BY-LAWS FOR THE GOVERNMENT OF}

THE PENDLETON FARMERS' SOCIETY.

Rule 1. At all meetings of the Society the President shall take the chair and call the meeting to order at $10 o^{\prime}$ clock a. $\mathrm{m}$.

RULE 2. Any member wishing to move a resolution shall reduce it to writing and address the chair standing. No resolution is to be open to discussion until it has been seconded, but the mover may state any..........observations touching the merits of his resolution before it is seconded.

RULE 3. No member shall be allowed to speak more than twice on any one subject without permission from the Society.

RULe 4. In all cases every member shall arise and address the chair uncovered. The member first up shall have the precedence. The President shall confine the attention of the Society to the member speaking, and not suffer him to be improperly interrupted.

RULE 5. In cases of more than ordinary interest the Society may go into committees of the whole on the requisition of any five members, when the President shall nominate a chairman, who shall preserve the same order and decorum, and cause the same rules of debate to be observed with the exception of the third rule.

RULE 6. The previous question may be moved and seconded at any stage of the debate in committees of the whole, and shall be in the following words: "Shall the main question be now put?" Should the committee decide in the affirmative the main question shall be put without debate.

RULE \%. Whenever a resolution has been disposed of by a vote of the Society, it shall not be in order to move that or a similar resolution without a vote of the Society to reconsider.

RJLE 8. Every member of the Society who shall violate any of these rules and who shall not conduct himself with decorum and......... both of language and manner shall be called to order by the President and if necessary be directed to take his seat. 
Rule 9. In cases of gross........., violent and ungentlemanly conduct the Society may expell a nember, the resolution for this must be signed by two nembers who should name it silently to the President who is bound not to disclose their names, and who is to request the member to withdraw, after the debate the member shall be introduced and informed of the substance of the charges and is required to make his defense after he returns, either at the moment or at the next meeting, when a vote is taken, and it shall be by balkot, and shall require two thirds of the meeting and which shall consist of at least threefourtlis of the regular members, to expell a member.

Rute 10. All applications for admission to the Society, and all resignations must be made in writing.

RuLE 11. All members who have paid their dues, and desire to be still members are requested to sign the by-laws. 
CHAPTER V. 


\section{DECLARATION AND PETITION FOR INCORPORATION.}

The original charter of this Society was granted in $181 \%$. The undersigned declarants and petitioners,

NAME,

ADDRESS.

J. C. Stribling $\ldots \ldots \ldots \ldots \ldots \ldots \ldots \ldots$ Pendleton, S. C.

B. Harris $\ldots \ldots \ldots \ldots \ldots \ldots \ldots \ldots \ldots \ldots \ldots \ldots \ldots \ldots \ldots$ Pendleton, S. C.

C. L. Newman .................. Clemson College, S. C.

J. B. Harris .......................... Pendleton, S. C.

H. C. Summers, Jr. ................ Pendleton, S. C.

J. N. Harper ..................... Clemson College, S. C.

being two or more of the officers or agents appointed to supervise or manage the affairs of the Pendleton Farmers' Society, a corporation which has been duly and regularly organized for the purpose hereinafter to be set forth, do affirm and declare:

That at a meeting of the aforesaid organization, held pursuant to the by-laws or regulations of the said organization, they were authorized and directed to apply for incorporation.

That the said organization holds, or desires to hold, property in common for the Religious, Educational, Social, Fraternal, Charitable or other eleemosynary purpose, or any two or more of said purposes, and is not organized for the purpose of profit or gain to the members, otherwise than is above stated, or for the insurance of life, health, accident or property.

The said declarants and petitioners further declare and affirm:

1. Their names and residences are as above given.

2. The name of the proposed corporation is The Pendleton Farmers' Society.

3. The place at which it proposes to have its headquarters or to be located is Pendleton, Anderson County, South Carolina. 
4. The purpose of the said proposed corporation is to further interest in agricultural pursuits.

5. The names and residences of all managers, trustees, directors or other officers, is as follows:

President, J. C. Stribling, Pendleton, S. C.; Vice-President, B. Harris, Pendleton, S. C.; Corresponding Secretary, C. L. Newman, Clemson College, S. C.; Secretary and Treasurer, J. B. Harris, Pendleton, S. C.; Executive Committee, H. C. Summers, Jr., Pendleton, S. C.; J. N. Harper, Clemson College, S. C.

6. That they desire to be incorporated in perpetuity. Wherefore your petitioners pray that the Secretary of State do issue to the aforesaid The Pendleton Farmers' Society Certificate of Incorporation, with all the rights, powers, privileges and immunities, and subject to all the limitations and liabilities conferred by an Act of the General Assembly of South Carolina entitled: "An act to provide for the incorporation of Religious, Educational, Social, Fraternal or Charitable Churches, Lodges, Societies, Associations. or Companies, and for amending the charters of those already formed and to be formed," approved February 19 A. D. 1900 , and other provisions of law.

Given under our hands and seals, this 21st day of May, A. D. 1908.
J. C. Stribling,
B. HARRIS,
C. L. Newman,
J. B. HARRIS,
H. C. Summers, JR.
J. N. HARPER. 

CHAPTER VI. 



\section{MAJOR GEORGE SEABORN.}

Major George Seaborn, once president of the Pendleton Farmers' Society was born in Greenville District, South Carolina on August 1, $179 \%$, on Golden Grove Creek. He moved to Pendleton in 1840 and was president of the Society afterwards, and took a great interest in all things pertaining to Agriculture.

He wrote a great deal on the subject and was long a correspondent of the Southern Cultivator and the American Farmer of Baltimore, Md., and other Farm Journals.

In 1850, he in connection with Mr. J. J. Gilman of New Hampshire established the Farmer and Planter a paper devoted to the farming interest at Pendleton under the firm name of "Seaborn \& Gilman." Mr. Gilman soon retired and Major Seaborn continued the publication until 1859 .

Major Seaborn married Sarah, a daughter of General John Baylis Earle. He died at his home near Pendleton, on March $187 \%$.

I have a very distinct recollection of the old court-house as it stood in 1840 and 1841 and afterwards. Whether it was completely finished I can not certainly say, but it looked all right to me. It had on a roof and within were raised seats like all the old court-houses had in that day, the back seats being raised 7 or 8 feet higher than the front ones. I remember that particularly and think I can now see the judge's bench and the bar as it was then. I was in the building once at some sort of a public meeting, I don't know now what, and remember when the "ayes" and "nays" were called for on some question or resolution, Thos. J. Sloan, a twelve or fourteen-year old boy, answered "aye" with the others, and we boys thought he had committed the unpardonable sin and expected to see him summarily executed. This was after we had moved to Pendleton and I was a schoolboy.

I don't know when the building was commenced. It might have been in 1826, but my supposition has always been that the old Pendleton District was not divided into Anderson and Pickens until 1828. I don't know that court was ever held in that building, that was before my time, I was born in 1831 . 
I don't know how the building came into the possession of the Farmers' Society, but know that it was torn down and the Farmers' Hall was built of the material, which was probable as the court-house was larger than the Farmers' Hall. When the Hall was in process of building, a thunder storm came up one night and the lightining struck one of the scaffold poles on the east side next to where the Masonic Hall now is, and shattered it to splinters.

When the school teacher, Mr. J. J. Gilman, sprained or broke his ankle once and could not walk except on crutches, he taught in the Farmers' Hall a good while lying on a cot.

The two north rooms of the ground floor was used for some years as the printing office of the Farmer \& Planter an agricultural journal published by Seaborn and Gilman, but this is of so recent a date that I suppose it is remembered by many persons now living there. The publication was commenced about 1850 .

Col. Edward Harleston once occupied the lower northwest room as a Law Office for a short time, and we all remember J. J. Dukes's Ginger Pop Shop in the southwest room and T. J. Wernen's tailor shop in southwest corner.

The traveling shows used to exhibit in the large hall above, and a company of North Carolina Indians once held a Green Corn Dance there to which they charged an admission fee.

I have been told that the first court-house at Pendleton was situated down on the branch where Shanklin's Tan Yard afterwards stood. In one of the record books in the Clerk's Office at Anderson is recorded the contract for building the first courthouse. It was to be of $\operatorname{logs}$ and the size and length of the logs were specified. In the same record is the deed to the land where the village of Pendleton was built.

I could make this account fuller perhaps, but it would be more a history of Old Pendleton than of the Farmers' Society, which I don't suppose you care for.

\section{Very truly,}

\section{James SEABORN.}

If I had the time T would be pleased to contribute something to your history. You know I helped print the "Pendleton Messenger" in 1857 and 1858 when it was owned and edited by Seb Symmes, son of Dr. Symmes. 
The paper was moved from Pendleton to Hartwell, Ga. and from the material was printed the "Hartwell Messenger." Warren D. Wilkes, a distinguished man of Anderson, assisted in editing the paper. While the paper was printed at Pendleton I was the "Printer's Devil" and as the "Carrier Boy" I distributed the "Messenger" to its 80 or 100 subscribers all over the town.

I remember very pleasantly many of the distinguished citizens of Pendleton and community, amoug them was the wife of John C. Calhoun, who always had a pleasant word with me as I carried the paper to her home every week. She lived at the place now owned by Mr. Henry T. Sitton on the right of the public road leading to Autun, S. C. and Anderson, S. C.

Pendleton was at that time a thriving, business town, with two hotels and many stores all around its square. The Blue Ridge Railroad had just been completed to that point and the cars were making daily trips between Anderson and Pendleton.

I have always had a warm place in my heart for Pendleton and its intelligent and sterling citizens. No better people live anywhere than those of Pendleton and surrounding community.

Wishing you and your co-laborers great success in your under. taking, believe me your friend and fellow citizen.

D. A. Sмiтн. 

CHAPTER VII. 


\section{GOV. PERRY'S ADDRESS TO PENDLETON SOCIE'TY.}

VALUABLE HISTORIC PAPER PRINTED THROUGH COURTEST OF COL.

J. C. STRIBLING-ADDRESS WAS DELIVERED BEFORF,

THE PENDLETON FARMERS' SOCIETY

IN THE EARLY EIGH-

TIES.

Address delivered before the Pendleton Farmers' Society, October, 1884 .

Gentlemen of the Pendleton Farmers' Society:

I have been invited, as the oldest surviving member of your Association, to address you on the 69th Anniversary of your Society. I duly appreciate the honor, but feel a difidence in attempting to discuss the great and all important question of agriculture, before intelligent, educated and practical farmers, such as you are.

I was brought up on a farm, in Pendleton district, and accustomed to all the duties and labors of a farmer; but soon entered on professional duties which, for more than half a century, have withdrawn my attention from this, the noblest occupation of man. I have, however, never lost an interest in agriculture, and have read and studied much on the subject. I am now living on an extensive farm and in some measure supervise it, which is under the direction of my youngest son. I have noticed with great pleasure the progress of agriculture and the wonderful improvements, in agricultural implements, since my youthful days as a farmer.

The "Pendleton Farmers" Society" was organized in 1815 and is now one of the oldest agricultural societies in South Carolina. That its existence should have been continued so long is highly 
creditable to the agriculturists of this community. It speaks well for their intelligence, patriotism, science and love of improvement.

The war with Great Britain had just closed, before the organization of your society, and the country was greatly depressed in all of her resources and industries. Agriculture and commerce were especially at a low ebb. The farmers around Pendleton village, in 1815, were educated and highly cultivated citizens, and many of them quite distinguished in the State. I may mention Governor Andrew Pickens, and his brother Ezekiel Pickens, sons of the patriot and Revolutionary General Pickens; Col. Robert Anderson, the son of another Revolutionary General, and for many years Clerk of the House of Representatives; Col. Warren, a gallant soldier of the Revolution, who lost a leg in the war of Independence, and for many years a representative in the Legislature from Pendleton District; General J. B. Earle, a member of Congress, and for many years Adjutant General of the State; Samuel Earle, a member of Congress; Mr. North, a highly cultivated gentlemen and of great moral worth; Thomas Harrison, a distinguished lawyer, and State Treasurer John E. Calhoun, the son of one of our first United States Senators, and an accomplished gentlemen; Col. Richard Lewis, Joseph Whitner, Mr. Gaillard, the Taylors, Maxwells, Sloans, Bensons, Cherrys and many, very many others of fortune and cultivation. These pa. triotic gentlemen farmers determined to try and advance the cause of agriculture in their district, and hence the origin of the "Pendleton Farmers' Society." To the credit of your district this Association has continued to flourish, and has added to its members, John C. Calhoun, Vice-President of the United States, John Gaillard, President pro tem of the Senate of the United States, Judge Cheves, one of the purest and wisest men South Carolina ever produced, Governor James Hamilton, the Bayard of the South: Col. Francis Huger, the liberator of Lafayette from the dungeon of Olmutz; Col. Thomas Pinckney and Charles Cotesworth Pinclney; the Hon. Richard F. Simpson, for many years our representative in Congress, and many others of the most distinguished men of the State.

Some thirty or forty years ago I was invited by my friend, Major George Seaborn, then President of this Society, to address its members at one of their anniversary meetings. When I look 
around me now, I see but two members (Mr. John Sitton and Mr. Gaillard) of the Pendleton Farmer's' Society who were then present on that occasion. They have all gone to that bourne from whence no traveler ever returns-John C. Calhoun, Governor Burt, Dr. Symmes, Major Seaborn, J. Overton Lewis, the Taylors, the Maxwells, the Bensons, the Sloans, and others, who were here then, are here no longer.

And what great events, my friends, in the history of our country lave taken place since that period. A civil war has swept off hundreds and thousands of our most gallant and patriotic sons, fallen in battle with the lost Confederacy, the Sonthern States have been depleted by hostile armies, and our slaves emancipated. But worse than all this, those freed negroes were set orer us, as our political masters, under the control of rogues and scoundrels from the North, who came here to steal and plunder. Nothing in history is more infamous than this cruel ontrage, on the part of the Republican party of the Northern States.

But in 18\%6, the Centennial of American Independence, the white, noble people of South Carolina, under the patriotic and gallant lead of General Wade Hampton rose up in mass, and proclaimed that they would no longer submit to be governed by ignorant negroes, plundering carpet-baggers and infamous scallawags. In the providence of God this morement was successful, and the leaders of that regime have fled from the just indignation of an outraged people. R. K. Scott, the Radical Governor of South Carolina, fled with his stolen wealth to his old home in Ohio, where he murdered an innocent young man, who was trying to conceal the disgrace of his son. F. .T. Moses, the successor of Scott, in the Executive chair of debased and degraded Radical South Carolina, fled to New York, where he has been convicted of crimes and sent to the penitentiary several times.

Since this overthrow of negro carpet bag, scallaway rule, in South Carolina, we have made rapid strides in all the branches of industry. Agriculture has revived, and our crops are almost doubled. The white people have put their hands to the plow and are no longer above cultivating their farms by their own manual labor. They have been greatly aided. ton. Jy the recent wonderful improvements in all agricultural implements. The Sulky plow; the reaper, the steam thresher and a variety of other labor- 
saving machinery, have almost made the farmer independent of his colored hireling. Mason's machine for picking out cotton, the most wonderful invention of the age, will make him more so.

The phosphates, too, have come to the aid of the farmer and thrown a flood of fertility all over the State. By means of this manure, cotton is grown at the foot of the mountains. Before the discovery of phosphates, there was not a bag of cotton sold in the town of Greenville, and since the use of this fertilizer, thirty thousand bales have been sold there in one year. Its application to corn and wheat, and all the cereals, is equally advantageous.

But there is danger in depending too much on this expensive fertilizer instead of stable and barnyard manures and compost heaps. When well applied these manures are as good as phosphates and much more permanent. They are not so easily carried out and applied to the fields, and they are more troublesome to make and preserve. This is one reason why the phosphates are preferred. In the early history of agriculture in South Carolina, no one thought of manuring his land. This was too much trouble. The farmers thought it better to clear new land, wear it out and move off to a fresh country. This vicions custom has cost Sonth Carolina millions of wealth and thousands of her citizens. How great would our State be to-day if she conld reclaim all her emigrant citizens and the wealth they carried off.

The spirit of emigration weakens also the patriotism of the emigrant, and he no longer loves as he ought to, the home of his birth or the home of his adoption. But since the overthrow of Radical rule in South Carolina, this spirit of emigration has ceased, and everyone thinks of improving his lands, instear of wearing them out. In former times the ignorant farmer never thought of preserving his manures, and very often built his stables and cow lots on the side of a hill, so that the rains and floods might keep them clean. I have heard farmers say that they never manured a foot of land in their lives. Now, there is scarcely a farmer, no matter how ignorant he may be, who does not try to manure as much of his cultivated fields as possible.

In the early history of South Carolina, the largest portions of the lanis were in wonds, and cattle were permitted to range over it at pleasure. The Legislature passed laws requiring everyon to fence his fields, and declared how high a lawful fence should 
be. But a few years since, the legislation was most wisely changed, and an Act was passed, requiring everyone to fence his stock, and authorizing the farmer to cultivate his fields without any fence at all. I regard this "no fence law" as the wisest Act the Legislature has passed for many years past. The expense of fences in South Carolina was fire times more than the whole live stock of the State was worth. The wisdom of this law, in requiring all cattle to be kept up is seen all over the country, in the improved breeds of cattle, hogs, sheep. It is seen, too, in the increased and improved quality of butter brought to market. Instead of being engaged in the latter part of the winter and early in the spring, in making and repairing his fences, the farmer now has time to haul ont his manures, and make a thorough preparation for his crop.

The first consideration of every farmer should be to drain his low grounds thoroughly, and keep his uplands from washing by deep plowing, sowing them in small grain and clover occasionally, and hill-side ditching if necessary. Deep subsoiling will almost render the farmer independent of ordinary droughts. In order for the roots of plants to extract the fertility of the soil, it should be well pulverized, and no clods left unbroken. When the ground is well broken and pulverized and deeply subsoiled very shallow ploughing afterwards is best for the crop. It is a mistake to suppose that breaking roots improves their growth. As well might we expect to increase the volume of water in a creek by cutting off the spring branches which feed it.

It is a great mistake to plant so much cotton as we do, and depend on the great West for our corn, flour, bacon, lard, horses and cattle. It is doubtful whether there is any profit in growing cotton under ten cents. When the planter sells his cotton and purchases his supplies he will very often find himself in debt. $\mathrm{He}$ shonld make corn, wheat and meat enough to do him, and raise his own horses, mules and cows. Then he may plant as much cotton as he can cultivate. But there are a great rany crops more profitable at this time than cotton. I ti,ink tobacco is one of them. So are the grasses. when weil sured and fed to the stock. They improve the Jand ton, and keep it from washing. Lncerne is one of the finest grasses the farmer can grow, and it may be cut three or four times during the season. It is very nutritions and stock are fond of it, green or cured. General 
Davis, whilst our minister to France, said he saw the peasantry of that country eating it as greens.

It requires less labor to grow wheat, rye, oats, barley and the grasses, than it does to grow cotton; and this should be an inportant consideration with the farmer, who has to hire labor. These crops too, are more profitable in proportion to the labor in raising them, than cotton. They also improve the land, instead of wearing it out, as cotton does.

For many years it was supposed that the grape culture would never succeed in the United States. In 1846 I visited Mr. Edward Everett, then President of the Cambridge University. $\mathrm{He}$ had been minister to Great Britain, and traveled all over Europe. He said to me that we never conld succeed in cultivating the grape, that there was something in our climate which made grapes inferior to those of Europe. He remarked that the Chinese who lived in the same latitude that we do, on the other side of the earth, and were a very ingenious people, never had been able to make wine, and we could not in the United States. But within a few years after this conversation, wine was successfully made in Ohio and California. And it is now well known that the grape grows remarkably well in South Carolina, and that excellent wine is made in many parts of the State. Dr. Marshall, in his lifetime, planted a large vineyard on the side of Paris Mountain, in Greenville, and made several thousand gallons of wine. Mr. Buist, and several other gentlemen, living near Greenville City, have flourishing vineyards. Mr. Carpani, a Frenchman, has recently commenced a vineyard on a large scale, and so far has been successful. He says that our climate is better adapted to the culture of grapes than France. Mr. Garraux, a Swiss, has sold grapes this year, and made wine on one and a third acres, to the amount of six or nine hundred dollars, and I have seen it stated that Mr. Wanner, of Walhalla, has made on one acre, grapes and wine to the amount of seven or eight hundred dollars. How much more profitable, then, is the culture of the grape than that of cotton. It would be well for our farmers to take this culture into serious consideration. What a great blessing it would be, to have cheap wines, substituted for corn whiskey, in South Carolina, as a common beverage.

We might make sorghum a valuable crop, and it is easily cultivated, and converted into molasses. Thousands of dollars 
might be saved in making molasses out of sorghum, for our tenants and hirelings, instead of purchasing an article not superior, from New Orleans. At least every farmer might, at little expense, make enough for his own use. In course of time I have no doubt sugar will be made from sorghum molasses.

It is very gratifying to see the interest taken all over the country since the passage of the "stock law," in the improvement of cattle, hogs, sheep and horses. And perhaps, in no county in the State, is the interest greater than in and around old Pendleton, and it is manifested by the improved breeds of cattle and horses now on exhibition at this place. What a contrast between the fine Jersey and Holstein cows, seen here to-day, and the poor, scrub cattle that we used to see shivering in the winter rains and sleets, and fed on shucks and nubbins. The same contrast, too, may be seen in your breed of horses.

The agricultural interest of the United States is more important than that of any other, and yet it has been heavily taxed, by the present Republican party in Congress to protect Northern manufacturers, the National Government collecting one hundred million of dollar's over and above necessary expenses, extravagant as they have been. At this time there are four luundred millions of dollars lying idle in the Treasury, and yet the Pepublican party refuse to reduce the taxes paid by the people. The high tariff benefits only the capitalists, engaged in manufactures, and does not increase at all the wages of the poor operative. In $18+1$, before the present high war tariff was enacted, the wages of the operatives were higher than they now are. In England there are no free trade, no protection and their laborers are receiving higher wages than they did under protecting tariff. In Germany, France and Italy, where there is a high protection, the operatives do not receive as much for their labor as they do in England.

This injustice to the agricultural interests of the country is a great shame, but can not be remedied whilst the present Republican party are in power. Hence the ensuing election for President and members of Congress is of vital importance to the whole country, and especially to the Southern States. The Republican party has been in power more than twenty years and they have introduced corruption, trickery and swindling into every department of the government. During General Grant's administra- 
tion of eight years, the defalcations amounted to ten million dollars, stolen by the officers. In order to conceal their rascality the officers of the government have cut out leaves from public records and destroyed them. If there be no change soon our Republican system will be at an end and all boasted liberty sunk in corruption.

But I think it is almost as certain as any future event can be that Governor Cleveland, our Democratic candidate for the Presidency, will be elected on the fourth of November next. Then there will be a reform in all the departments of the Federal Government-corruption will be at an end, taxes will be reduced, economy will be practiced, the rascals will be turned out of office, the constitution rights of the United States respected and our Republican Government restored to its original purity. Then we may expect to see the country prosperous and manufacturers will flourish as they never did before in the United States.

The evil effects of a bad government on the prosperity and happiness of people are incredible to those who have never experienced them. In illustration of this truth, I would refer to the seven or eight years of Radical rule in South Carolina. All industries were depressed, the negroes were idle, and the whole people seemed to have lost all their energy, taxes were ruinous, our fields uncultivated, in thousands of instances farms were sold, too, to pay taxes, and the people felt degraded when they reflected that their belored State was under the regime of audacious rogues and ignorant scoundrels.

But as soon as the State threw off the government of the Radicals everything revived and our industries flourished, and the wealth of the State has been increasing five or six hundred thousand dollars every year since. We shall experience the same blessing when the Democratic party gets possession once more of the National Government. No nation in the world ever prospered more rapidly than did these United States for fifty years under the Democratic party. The purchase of Louisiana, the purchase of Florida, the annexation of Texas, and the acquisition of California, were all made by Democratic administrations. During this time, too, our shipping was on every sea and our commerce was spread over the world, our agricultural products were increased a hundred fold and our manufactures were in a most flournishing condition under a moderate tariff. The war with 
Great Britain and the conquest of Mexico were likewise under Democratic rule. The rights of our sailors were vindicated in the war with Great Britain and our National honor maintained in our conquest of Mexico.

In conclusion I beg to pay my respects to the ladies who have honored me with their presence here to-day. It is said to be happy you must have something to do, something to have and something to hope for. This is a wise saying and a most truthful saying. Then all farmers' wives should be happy. They have the full consideration of these three things in an eminent degree, besides the occupation of their ordinary household duties, they have their dairies to attend to, the milk of Jersey cows, the rich cream and golden butter to take care of and some attention to pay to their favorite live stock, feeding their poultry, etc. Besides their love for their husbands and the children, they have their pets to love, in fine horses, fine cows and fine dogs. Besides their hope for Heaven hereafter, they have to hope for good crops, increase of live stock, good seasons and many, very many, other things. But after all, our happiness in life depends very much on ourselves, our nature and our constitution which we may modify and improve but can not entirely change. Some persons are so constituted that they will be happy under any circumstances and in any condition of life, and there are others who will be happy nowhere and under no circumstances. It is their nature and they are to be pitied, not blamed.

And now ladies and gentlemen, wishing that we could live to celebrate the centennial anniversary of the Pendleton Farmers' Society, and see the wonderful improvements which will take place in agriculture in thirty-one years to come, I bid you an affectionate farewell. 
CHAPTER VIII. 


\title{
OLD PENDLETON.
}

\author{
By J. C. Stephens.
}

In Cotton Plant for April, 1890.

This spot has always been the home of an educated, intelligent and refined people, and to-day every town and city in this Statc, yea, in every city in the United States, has within its borders some citizens who have a tender spot in their hearts that are warmed with fond recollections of old Pendleton, and rejoice with her citizens in the new life of the town which is now booming up.

Clemson College is located in the edge of Oconee county not far from the corners of Oconee, Anderson and Pickens, something more than three miles from the hospitable and cultured town of Pendleton, and in one of the richest sections in the Piedmont belt.

The college is planted in good soil and the "child of the farm" (the college) will be reared in a healthy and prosperous farming community, whose reputation for good farmers and great statesmen is to South Carolina what Hempstead is to England. May the Clemson Agricultural College, perched upon an eminence amid the beautiful hills and rich valleys of the Piedmont, shine like a glittering star amid the darkest hours of every farmer of the State, and its influence for good be as bright as the noonday sun and shed its light upon every branch of industry within our State.

\section{PENDLETON FARMERS' SOCIETY.}

Among the noted members of this Society who have died since the war, are Maj. George Seaborn, who was proprietor and editor of the old Farmer and Planter, published at Pendleton, and Maj. R. F. Simpson, member of Congress and an able writer on subjects pertaining to agriculture, and father of Col. R. W. Simpson, the executor of the far-famed Clemson will-which was sustained in the Supreme Court of the United States, and a decision filed by that august body on the \%th of April, 188\%, also president of the board of trustees of the Clemson College. 
Thomas Stribling, one of the charter members of this Society is the father of Cornelius Kinchelo Stribling, who left his father's home near Pendleton at the age of twelve years, walking all the way to Charleston, S. C., and later at the age of eighteen, 1812, he entered the United States Navy as midshipman. From this adverse and trying tramp, in his start in life, this plucky young man made good at every station of promotion from midshipman to commodore, and finally was placed on the retired list as Rear Admiral of the United States Navy, and died in Martinsburg, W. Virginia, 1880.

Ex-Governor B. F. Perry, father of Congressman W. H. Perry, of Greenville, President O. A. Bowen, and Hon. Thos. G. Clemson, minister to Belgium under President Buchanan, a noted mineralogist and chemist for the Confederate government, soon after the war, while President of the Pendleton Farmers' Society, first began agitating the subject and feasibility of establishing a State Agricultural College, which culminated in the bequeathing at his death, "Fort Hill" plantation (the historical home of his father-in-law, John C. Calhoun), and a large endowment in money to establish and maintain an agricultural college at this place which is to-day the "Clemson Agricultural College" a household word in every farmhouse in South Carolina, and rightly the honor and credit of having given more substantial aid towards promoting the interest of the farmer than any other citizen of this State is due to Mr. Clemson, through whose efforts and gifts, mainly, South Carolina has an agricultural college second to none in the South; and the locating of this college at Fort Hill, under the shadow of the old farmers' hall of Pendleton, a veritable mother in agricultural institutions and progressive agriculture, seems in every way very appropriate.

Col. L. J. Allston was the son-in-law of Aaron Burr and subsequently Governor of the State. The name is a familiar one in Georgia. Rev. Dr. Waddell, as an educator of youth, attained 
a fame and made an impress that is felt to-day throughout the South. Col. Joseph Grisham was the father of Mrs. Senator Joseph E. Brown, and grandfather of Judge J. J. Norton. George Reese was the father of Dr. Milton Reese and Addison Reese, and the grandfather of Judge W. M. Reese, who has illustrated Georgia in high positions of honor and trust.

The fruits of the workings of this Society may be seen in the number of well tilled stock farms around it, which is said to contain more and a greater variety of fine stock than any other section of the State. On every side of town may be seen rich meadows and pastures corered with fine stock that are increasing in value and average.

'Truly the Pendleton Farmers' Society has been a mighty factor of good for the whole people. May it continue to live, labor and bless mankind forever. 
CHAPTER IX. 


\section{WHOLLY REMINISCENT.}

BY MAJOR BENJAMIN SLOAN, PRESIDENT OF TIIE UNIVERSITY OF SOUTH CAROLINA.

My earliest recollections are of old Pendleton. I was born on my father's plantation which was separated from that of Mr. John C. Calloun by the Seneca River. His dwelling-long since burned-stood upon the crest of a high hill three quarters of a mile, perhaps, lower down and on the opposite side of the river from that of Mr. Calhoun. Before I was old enough seriously to take note of things he moved his family (in 1838), to a home which he had prepared in the village of Pendleton, and from which he could still attend to the plantation. This he did that his growing family might enjoy the advantages of the excellent schools already established there. The smaller children, boys and girls, were taught by Miss Mary Hunter, one of three spinister sisters, from Pennsylvania, who resided in a little house where now stands the home of Mr. Norton Hunter. Her school house stood in the edge of the Oak Grove contiguous to the lot on which Mr. Miles Hunter now resides. In many instances two generations of children passed nnder her faithful hands. As soon as it was judged that a child was sufficiently well versed in the three R's, if a boy, he was passed up to the Male Academy, if a girl, up to the Female Academy, each of which was presided over by excellent teachers who were paid salaries-considering the cost of living now, and then-comparable with the salaries now paid to full professors in the State Colleges.

When I passed up to the Male Academy Mr. Joshua Gilman from Baltimore-a gentleman and a scholar-was the master. By means of his many attainments, his bonhomie and his firm character he kept the boys, large and small, well in hand. Even- 
tually he went to Mississippi, where he gained a competency and retired to an easier life. Up to the time of his death Mr. John C. Calhoun, as I remember it, was one of the school trustees. The school building, a wooden structure with two large rooms, was situated in the grove, close by the old Presbyterian Church, on the west side of the Greenville road. At one end of the larger room was a raised platform, flanked on either side by a small room used for storing globes-astronomical and geographical, and apparatus-physical and chemical. Well do I remember the experiments, usually made on Friday afternoons, with the various pieces of apparatus which for that period were quite up-to-date. The experiments made by means of the first-rate static electrical machine never ceased to startle me. The world was then, as now, groping in the dark to find out what was the nature of the "electric fluid." as it was then called; and, in spite of the wonderful uses to which electrical energy is to-day put, we are not one whit nearer to the discovery of the exact nature of electricity. It may be that we shall never know any more of its true nature than we know of the nature of that mysterious force which we have always with us-the force of gravity.

In the school building was also a good library. The books of Classical Authors (translations); of History; of Travels: miscellaneous books of Science and of Standard English literature were to be found upon its shelves. I believe all of these things have long since disappeared.

Boys were prepared in that school for the Sophomore Class of South Carolina College. If they did not go to college they were at least fairly well equipped to begin life's battle. They were well grounded in English--Smith's grammar was used as the grammar text book, and, in my opinion, there is none so good in use to-day. Spelling which is to-day, alas, a lost art was persistently taught from the "Blne Back Spelling Book." The study of the Classics, as far as it was pursued, was thorough, and every boy, whether he intended to go to college or not, might have his try in Latin, at least as far as Cæsar and Virgil; and in Greek, through Xenophon. And so too could he pass through the intricacies of the pure mathematics, mastering arithmetic, algebra, geometry and trigonometry. Surveying was well taught. Geography and history of course had their full share of attention. In short, at that time the Pendleton Male Academy 
was truly a "High School." Would that we had to-day such a school in every county of the State.

I might speak truthfully in terms of equally as high praise of the Female Academy which, as I first remember it, was presided over by the Misses Bates of Vermont-and most accomplished women they were. After teaching in Pendleton for many years they went to Charleston, S. C., where for years they conducted successfully a school of high order. These ladies were followed by the Goulds, father and daughters, from Baltimore; and then came Miss $J$ ebb, a highly cultivated Irish woman, and while she was still there, (1852), I myself left the dear old village to try my fortune in the wider world beyond. Since that time only at fitful periods has my residence been in Pendleton, or in its neighborhood.

A "Labor School," as it was called, a school where boys were to be taught how to grow crops, to do carpenter's work, etc., had been at one time established on a farm several miles distant from the village. I believe the farm was afterwards owned by the father of Col. Richard Simpson. Its management, however, proved to be a dead failure, and the school soon perished. This event occurred, however, before my time.

In those days, it seems to me, that the youths of society were not so cock-sure, as they are to-day, that they knew everything worth knowing and that they, only, knew what to do and how to do. On the other hand, intuitively they seemed to appreciate the fact that there was still before them a sterner school into which they really were not prepared to enter even as "preps." At any rate the memory of the high regard and esteem in which the older generation was then held by the members of the younger generation is still fresh with me.

A reference to the annual rolls of the Pendleton Farmers' Society, from its birth in 1815 through the first half of last century, will fully justify this tribute from the young people of that day, and commands, equally, respect and admiration from us grown-mp people of to-day. What an array of names of illustrious men do those rolls present. Con it for yourselves from the history of that famous old Society published in this book. Their descendants are now to be found in every part of this State and, indeed, in every part of the United States.

The resident members were, in the main, sons of men who had 
first wrested that beautiful country from its savage wildness and then had given their strength and help in wresting it from British rule.

The Honorary members were, chiefly, non-residents; many of them, however, had summer homes, these were from Charleston and the coast, in the immediate vicinity of Pendleton. Mr. Calhoun's residence was within a few miles of the village, but his public duties demanded the greater part of his time in Washington. All of them were men of refinement and high culture. The names of many of them are identified not only with the history of South Carolina, but with the history of the United States.

No wonder that old Pendleton should have been so aggressively progressive in eliminating savagery and in upbuilding civilization. Excepting Charleston, here was established the first newspaper in the State, The Pendleton Messenger, and the first farmers' society, the Pendleton Farmers' Society: and here, too, was established one of the first agricultural magazines in the South, The Farmer and Planter, and here also was established one of the first mills in the South for spinning the cotton fibre into thread and weaving it into cloth, the Pendleton cotton factory.

The schools have already been spoken of. No wonder they flourished as they did. The constant thought and care of these men gave to them life and nourishment, and from the lives of the men themselves inspiration was drawn.

I can add nothing of value to the history of the Society. Youthful impressions are all I have to draw upon. At its annual fairs, usually, were gathered many notable men. Mr. Calhoun, if he was at home, always attended. He gave to farming much serious thought, as he always did to things which he thought worth pursuing at all, and introduced into the neighborhood many improverl farming methods; for if Mr. Calhoun did a thing, reasoned his neiglbor, there must be something in it. I think he is responsible for the introduction of hill-side ditching for protecting the hills from gulleying; terracing, however, has sinced proved to be a better method. His practice induced farmers to plow deeper in preparing land for crops; he brought to their attention methods of selecting seeds for sowing, and I think he introduced Bermuda grass into that section of country, 
a grass which is really a blessing to us of the South, but one which provokes the ire of a ploughman.

I remember particularly his presence at one of the annual fairs and the great interest which he, as well as all the other gentlemen present, took in a "sub-soil" ploughing match. The match was held on the fair grounds in a lot adjoining Mr. W. H. D. Gaillard's garden, the Methodist parsonage now occupies the same space. Each exhibitor had his own plough-share and stock both home-made. The plough which even so youthful a lad as I readily saw distanced all others had a share, made of a bar of iron about two and a quarter inches wide by three quarters of an inch thick with a small wing welded on to the flat side near the pointed end, which was appropriately and securely attached to the stock. The share readily penetrated the soil to a depth of from ten to twelve inches, while the little wing, acting like a "ground-mole" beneath, beautifully pulverized the earth above. I had the impression at the time and have borne it with me for years that this device was due to Mr. Calhoun; I have now, however, reason to believe that it was really due to Dr. Broyles. I have yet to see a better sub-soil plough.

I fancy I can now distinctly see Mr. Calhoun standing with face aglow, for the nonce all problems of statesmanship forgotten, watching the solntion of the problem of "sub-soil" ploughing.

In the forties of last century an effort was made under the auspices, I think, of the Farmers' Society to introduce silk culture into the neighborhood of Pendleton. At any rate the effort was made. Cocoons might be found in an outhouse of nearly every home, and "Multicanlis" trees, a rapid growing species of the mulberry, the leaves of which were to supply food for the silk worms, were rapidly and widely set, but the venture came to naught. There are, however, in the neighborhood, still, reminders of this venture. Cocoons of the silk worms may yet be found in many an old outhouse, and occasionally in the waste places may be found specimens of the "Multicaulis," I am not sure that this is the botanical name. And perhaps there may be still another reminder in Mr. Speaker Joe Cannon's suit of silk and wool, for the silk and wool were spun, and the cloth was woven not far away from old Pendleton.

In the days which have just been spoken of, Hamburg, dead 
now, was Pendleton's nearest market. In the fall, cotton, and whatever of salable produce might be on hand, was borne to this market in wagons which on their return brought back a year's supply of necessary goods, tea, coffee, sugar, molasses, salt, iron, etc., and such luxuries as the market could supply, and the weight of the pocket-book justified. All food stuffs other than those mentioned were produced at home. Each plantation was, in fact, as a separate principality. As far as victualing was concerned each might have stood a siege of considerable length, and in every way it was fairly well self-sustaining. Perhaps my father's was the most modest one of them all, but he had his carpenter, his blacksmith and wagon-maker, his shoemaker, carders and spinners of cotton and wool, looms and weavers of cloth, sempstresses and field laborers. There was a mill for grinding corn, machines for threshing and cleaning small grain (homemade both of them), a machine for husking and cleaning rice, a cotton gin and screw press (primitive both of them, it is true) and vats for tanning the hides of animals slaughtered. Horses, mules, cattle, sheep and hogs were bred and reared on the place. The planter truly lived at home, but his life was a busy one and full of responsibilities, and for his wife there was ever an imperative duty at hand. But it must be confessed that money was scarce. The price of cotton ranged from 5 to 6 cents per pound and corn sold from 40 to 50 cents a bushel; the latter was considered to be an excellent price.

The yield of cotton per acre was also small, due chiefly to the variety of seed planted. It was difficult to clear the seed (green in appearance), of lint even with the fingers, and the gin left so much of it clinging to them that each seed resembled a fluffy little ball. The staple was very short, and in harvesting the crop, the "locks" of cotton stuck so closely in the bolls that the very best "picker" could gather not more than 100 pounds per day.

The evolution of the many splendid varieties of cotton, now produced, from the old "green seed" cotton is due to the persistent and highly intelligent scientific work of individnals, throughout the cotton producing belt, who in turn have been stimulated to action by just such organizations as the pioneer of them all, the Pendleton Farmers' Society.

Before closing this paper it may be said, with emphasis, that it is eminently fitting that the great "Clemson Agricultural and 
Mechanical College" should be, as it is, firmly established on the lands of that farmer and exalted citizen and statesman who in loyalty and devotion to his State, stood pre-eminent, Mr. John C. Calhoun; and established, too, right in the heart of that country whose citizens took the initiative in organized effort to uplift the farmer and to magnify his calling. 
CHAPTER X. 


\section{Social Visiting Farmers' Club.}

The following epitome of the minutes of our Social Visiting, or Auxiliary of the Old Pendleton Farmers' Society is contributed by H. E. Ravenel, the prime promoter and diligent secretary of the club, and a son of $\mathrm{H}$. E. Ravenel, a prominent member of the old Society, who died in 1863.

\section{Pendleton, S. C., January 24, 1883.}

The Club met at Mr. J. C. Stribling's place. Present were, Rev. W. H. Hanckel, and Messrs. Taylor, Lewis, MeCrary, Ravenel,-Mr. Stribling in the chair.

It was resolved that it be made the duty of the present committee of four to draft an address to the Pendleton Farmers' Society to explain our object in joining it.

It was also resolved that it be recommended to every member of this Association to authorize Mr. Stribling to propose our names for membership at the next meeting of the Pendleton Farmers' Society; that it.is our sense that the same is a duty upon us; that it be made Mr. Ravenel's duty to inform the members of this resolution, and of the time of the next meeting of the Pendleton Farmers' Society.

The next meeting was appointed to be at the residence of Rev. W. H. Hanckel.

The business meeting adjourned. The Club inspected Mr. Stribling's silo. It exhibits very satisfactory and instructive results. The whole inspection and discussion was most beneficial. Proceeded to examine his premises, found all arranged for economy and convenience. Also grain and grass crops, giving rise to one of our customary instructive talks. Also an experiment in 
preserving potato vines in a bank, opened in the presence of the Club, and found all of the vines entirely rotten. The bank was not protected, and it was agreed that the experiment should be tried in a sheltered bank. We expect one or more members to do it next year. Also saw Mr. Stribling's application of grass terraces instead of hill-side ditches. He uses tall meadow oat grass, and is a clear adrocate of the system.

\section{Pendleton, S. C., April 19, 1883.}

The Club met at Mr. George E. Taylor's place. Present were, Mr. Taylor, Rev. Jno. B. Adger, Rev. W. H. Hanckel, Mrs: C. Hanckel, L. A. Bellotte, D. K. Norris, H. E. Ravenel, and J. E. Lewis.

The day was chiefly spent in discussing agricultural questions, with a due mixture of other matters.

Dr. Adger said that he wanted the opinion of the members on certain questions, to wit: He has a piece of difficult bottom which he wishes to put in grass, will it do to plant the land in corn, and sow the grass at the last working, or will the grass not stand the summer sun; that is, the kind we are accustomed to sow in this country. It was questioned then whether the land would not be too foul at the time, but Mr. Lewris proposed that the land should be planted in corn very late, say between the 1st and 10 th of June, so that it would not have time to get very foul, and it was thought by thorough preparation, late planting and careful working this difficulty conld be averted. Mr. Bellotte suggested that probably one bushel of peas sown with the grass would shade it from the excessive heat without choking it, ond would also improve the land when it died down. The idea was deemed uscful and practicable, the manner of getting rid of the corn stalks and stublle after harvest also received some attention. The result obtained by the doctor will be interesting, as the whole matter is new and experimental to those present.

The doctor further wanted counsel on the question of how to treat a very rough and obstinate hill-side next to his barnyard. It was thought he might succeed with Bermuda grass upon it, and so make it valuable.

Mr. Norris brought up the question of the limit of our production of cotton per acre, and the practical extent of our competi- 
tion with regions south and southwest. The comparison received some discussion, in which, without getting the most definite practical results, it was pointed out that we must admit our climate and lands to seem by present indications not such a natural home for cotton as the middle or coast sections of South Carolina, and other regions similarly situated, but against this we set our ability to raise more grasses and better stock, to drink purer water, to live on our plantations all the year, and to preserve health.

Further, experience justifies the expectations that we may produce a bale of cotton to the acre, without manuring to excessive cost.

Mr. Ravenel asked some questions about planting cotton in checks, and the putting seed immediately on acid phosphate, which last he had done to a small extent this year, the first to a large extent. Mr. Norris stated that he had seldom seen a good stand of cotton in checks, and thought it would be well always to drill seed, and then plow out if checks were desired. Mr. Bellotte said that he had planted seed on a limited quantity of acid, with good results.

A matter of much importanee was brought to attention, touching the produetion of crab grass for hay, its value and its relation to other grasses, as affects us. Mr. Norris points out that crab grass is indigenous here. If fertilized, turned over and left a certain period of the year, say from the 15th of May till the middle of summer, most land in this country will of itself produce one to two crops of luxuriant crab grass, and after removing the crop, afford an excellent pasture till frost. The grass is easily cured, makes far better hay than much that is put on the market, is palatable and nutritious. Mr. Norris had much experience with it in the middle country, and some members use it quite largely here. With this at our doors, why do we seek to import so many grasses at such expense, beyond what we need simply for winter pastures? The question received no satisfactory reply.

In relation to the question of excessive manuring of land, the Rev. Mr. Hanckel gave the result of an experiment made in the low country which went to show that there is no such thing as over-manuring. 
Mr. Taylor did not take the Club over his place, giving for his modest reason the explanation that he had really nothing to show, but we saw from his piazza some very attractive fields of grain, and a young orchard which, in future years will cause the Club to appoint his day in the fruit season; and the dinner, presided over by Mrs. Taylor, gave proof of a garden about which the rest of the company indulged in savagely remarks, while our jealousy in no way impaired our appetites. The secretary thought the other members had better not tell their wives what Mrs. Taylor had, and the other members thought the secretary had better get a wife to be told.

Adjourned soon after dinner.

Henry Ediund Rivenel, Sec.

Pendetenon, S. C., May 17, 1883.

The Club met at the residence of Mr. D. K. Norris. Present were Messrs. Norris, Harris, C. Hanckel, Taylor, Stribling, McCrary, Lewis, Ravenel, also Messrs. Caldwell, Henry S. 'Trescott, and Miles Pickens, who were with us for the first time, in all.

Mr. Norris after some arguing, took the members over portions of his place. The spring oats seen were not very promising, and Mr. Norris said that he had seventy acres in the same condition, and no fall oats. The crop was a sight to be regretted. The season seems to have been generally unfavorable to spring oats, and on Mr. Norris' place the later droughts have been especially damaging. Going on, we saw many acres of very fine wheat, promising excellent yield. It was on fresh ground, Mr. Norris' place being entirely or almost entirely, land which he has cleared in the last few years. He moved upon it a few years ago when all was forest, and has subdued and brought into good tilth several hundred acres of strong, well laid land. We saw a part of his cotton crop, looking well.

We also saw his underground drains, simply two boards nailed together like a trough, and put in inverted. One which was seen to be doing its work well by a copious discharge of water, Mr. Norris said had been put down for five years. Others had been in the ground shorter periods.

In the bottom drained by these instruments Mr. Norris hopes 
this year to make one hundred bushels of corn to the acre. We shall take interest in the result.

At the house a business meeting was held. The minutes of the meeting previously held at Mr. Stribling's and Mr. Taylor's places were read and confirmed.

On motion it was resolved that a special subject be discussed at every meeting, one gentlemen to be first heard on each side, and then the debate to become general. The subject chosen for next meeting is: "Crab-grass as a money crop; viewed also in its relation to domestic consumption, and in relation to other grasses."

Mr. Norris was appointed to present views in favor of crab grass, and $\mathrm{Mr}$. Stribling against. The subject has already some informal discussion at more than one meeting.

The next meeting was called at Mr. Ravenel's for June 21st.

The Club was entertained at dinner, presided over by Mrs. Norris, and after considerable time spent very agreeably the members dispersed.

Henry Edmund Ravenel, Sec.

Pendleton, S. C. June 21, 1883.

The Club met at the residence of Mr. H. E. Ravenel. Present were Messrs. Lewis, Taylor, Norris, Rev. W. H. Hanckel, C. Hanckel, Trescott, Bellotte, Ravenel, and also the following visitors, Mr. B. Frank Sloan, Mr. L. W. Jordan, both of Seneca City, and Messrs. S. P. Ravenel, and S. P. Ravenel, Jr. of Highlands, N. C. ; and also Messrs. D. and M. P. Ravenel of Keowee, S. C., and Mr. C. C. DuBose of Keowee.

Some inspection of the Ravenel's farming was made, though the day was too hot to go far. The Club saw some checked cotton, and several acres of cotton manured with about $2500 \mathrm{lbs}$. of the Furman Formula to the acre, under several different methods of application, of some of which Mr. Bellotte gave particular explanation.

The Club also particularly inspected experiments with Bermuda grass on uplands, so far very unpromising, and suffering from drought.

On entering the house dinner was had, presided over by Mrs. Ravenel. Afterwards a business meeting was held, the Secretary in the chair. The minutes of the last meeting was read and ac- 
cepted. Mr. Norris delivered a well received talk on crab grass, Mr. Stribling, who had been appointed upon the discussion, was absent.

On motion, the following subject was adopted for the next meeting: "Oat culture, with special consideration of the question whether or not oats should be planted in cotton. Messrs. Lewis and Ravenel were appointed to lead the discussion.

The meeting was fixed for July 19, at Mr. J. E. Lewis' place. Adjourned.

Henry Edmund Ravenel, Sec.

Pendeleton, S. C., August 16, 1883.

The Club was called to meet to-day at the residence of Rev. Jno. B. Adger.

Present were Dr. Adger, in the chair, Messrs. McCrary, Lewis, Trescott, Stribling, and Ravenel, and Mr. W. M. Porcher of Berkley County, a guest.

There was something interesting and a good paper read from Mr. Stribling on the subject of preservation of land from washing. He advocated doing away with ditches on hill-sides. Some of those present were convinced by their experience that the system would not do on steep lands. No method of saving washing bottoms seemed to be known or imagined, unless it be setting them in grass. A system of ditching and banking on outer angle has been spoken of favorably for narrow creek bottoms. Much discouragement was expressed at the want of interest in the club on the part of many members.

Those present sat down to a hospitable dinner. The next place of meeting was necessarily left unsettled, to be fixed by the Secretary on consultation with certain members.

Henry Eduund Ravenel, Sec. 

CHAPTER NI. 
THE BEGINNING OF CLEMSON COLLEGE.

\section{Planting the Germ That Grew Up Into Clemson Agricul- tural College, South Carolina's Great Institution of Learning in Successful Operation.}

At an impromptu meeting held in Pendleton Farmers' Hall the 24th of November, 1866, the following named members were present: Hons. Thos. G. Clemson, William H. Trescott, Hon. R. F. Simpson, Rev. A. H. Cornish, Rev. Hugh McLees, Maj. Benjamin Sloan, Col. W. A. Hayne, Dr. P. H. E. Sloan.

At this meeting a committee consisting of Hon. R. F. Simpson, Col. W. A. Hayne, Hon. Thos. G. Clemson were appointed a committee to appeal to their fellowmen for aid to found an institution for educating our people in the science of agriculture. This committee then engaged Hon. W. H. Trescott to draft the following circular letter as an address from said committee to the people.

Dr. P. H. E. Sloan who has held the Secretary-Treasurer office of Clemson College since the college was founded up to date, and held same position of Pendleton Farmer's' Society from 1875 to 1886 , endorses foregoing statement as follows:

The above meeting was held in my office, and is correct.

(Signed) P. H. E. SloaN.

\section{JANUARY, $186 \%$.}

At a previous meeting. held the 24th of November, 1866 , Hon. R. F. Simpson, Col. R. A. Hayne and Hon. Thos. G. Clemson, were appointed a committee to appeal to their fellowmen for aid to found an institution for educating our people in the sciences, to the end that our agriculture may be improved, our worn and impoverished lands be recuperated and the great natural resources of the South be developed.

Whereupon at a subsequent meeting of the said Society held as above (January, 186\%). The Hon. Thos. G. Clemson addressed the Society in an interesting and most able and instructing discourse and submits the following appeal, in the form of a circular which by direction of the Society was printed and fully circulated, both at home and abroad. At the same meeting many interesting addresses and essays were delivered and read to the Society by Mr. R. A. Maxwell, Col. Livingston and others, after which the Society adjourned.

T. S. Hayne, Sec. T. R. S., S. C. 


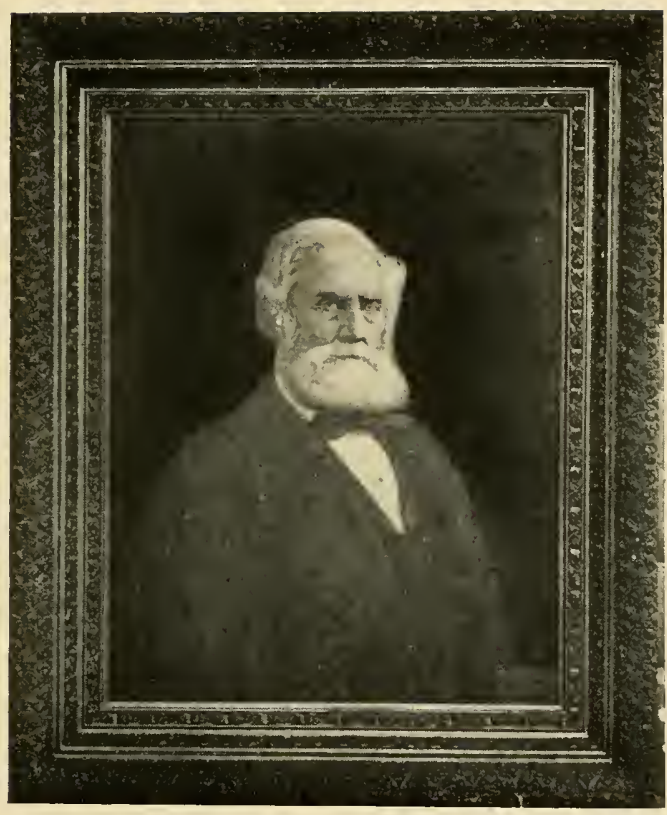

Thom is Greex Clemson. 



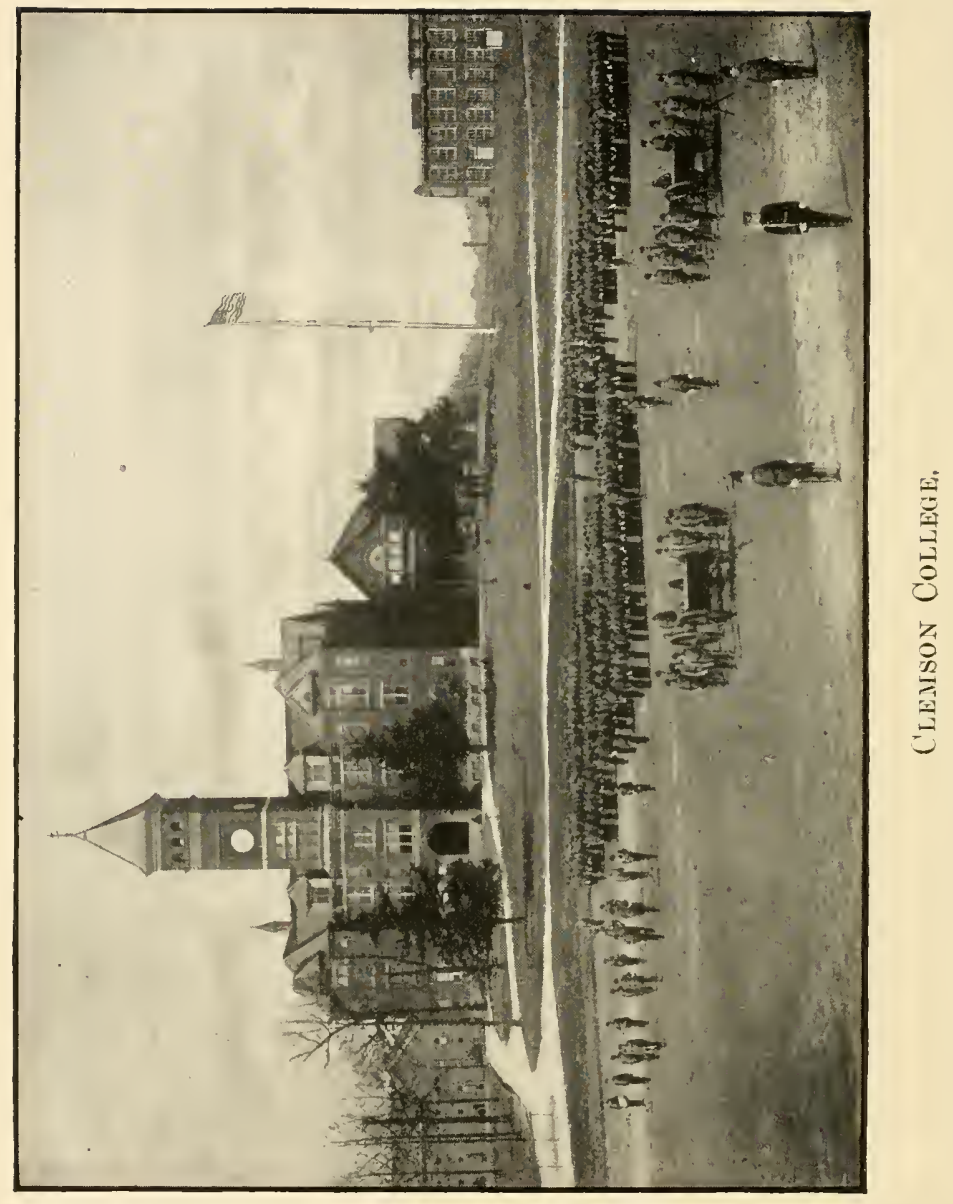




\section{CHAPTER XII.}


WRITTEN BI HON. W. H. TRESCOTT.

At the meeting of the Agricultural Society of Pendleton, S. C., held on the 24th of November, 1866, in its hall at Pendleton, Anderson District, Hon. R. F. Simpson, Col. R. A. Hayne and Hon. Thomas G. Clemson were appointed a Committee to appeal to their fellowmen for aid, to found an institution for educating our people in the sciences, to the end that our agriculture be improved, onr worn, impoverished lands be recuperated, and the great natural resources of the South developed.

Considering the prostrate, and almost hopeless condition of our country; our cities, churches, farm-houses, fences burned; our banks, railroad companies, and other institutions which held the savings of the old, the helpless, the orphans, etc., made bankrupt; our plate, watches, furniture, cattle, horses, the trinkets and clothing of our women and children, even the contents of our granaries and meat-houses carried off or destroyed; a large portion of our most productive lands sequestered from their owners to the freedmen; we are grievously taxed without representation; our property under the Constitution liberated without compensation; we have been left without food, or the means with which to purchase that which the harvests have failed to produce.

Considering that our lands are so impoverished by the growth and exportation of cotton, that much of them will not pay the cost of cultivation, and that our agriculture generally is in a wretched condition; that legislation has failed to protect the agricultural resources of the Commonwealth from unnecessary and wholesale spoliation; that we have emerged from an unmerciful war, in which we engaged to support a Constitution under which we were born and educated, and find ourselves ruined, but with natural resources undeveloped; our population leaving their smouldering homes for other and far distant lands; our mineral wealth no less varied, than vast, intact; our immense water powers without application, either to irrigation or manufacture; our best lands undrained, unprofitably luxuriant, and rife with pestilential emanations; that avenues to honor and wealth are restricted for the want of science, upon which the arts are based, and without which civilization can not advance; and that ignorance is the cause of our destitution, and the parent of crime, mis- 
ery and death. We, the Committee on behalf of the Agricultural Society, and our fellow-citizens, now make this our earnest appeal to the well-disposed of all classes and sects, for aid to found an institution for the diffusion of scientific knowledge, that our civilization may advance, and we may once more become a happy and prosperous people. We believe without such institutions, we shall ever continue to be at the mercy of ignoraut politicians and demagogues; but with them, we have a hopeful, if not a bright future for our descendants. An appeal more exalted and beneficent in design, for a people more deserving, was never offered for the consideration of the civilized world.

If this, our prayer, meets with sufficient response, an institution will go into operation from whence science of the highest order, in all its forms, will be gratuitously dispensed to unborn millions.

This upper region of South Carolina would appear, above all others, adapted for the location of such an institution. For the picturesque, this mountain region will vie with Switzerland. For health and climate, it is not excelled, if equalled, by any portion of North America.

Donations of funds, books, apparatus, are earnestly solicited, and considering the purposes of the Society, it is hoped that all public carriers, railroads and express companies will exempt packages from charges.

A record will be carefully kept and handed down to posterity, accrediting the donors for their respective contributions. Agricultural and other societies, and those who may have influence, would confer obligations upon the Society by acting as agents in collecting and forwarding contributions.

Editors of newspapers, and other publishers, are respectfully requested to give insertions to this appeal, that it may meet the eyes of all who feel an interest in the advancement of civilization in this ruined, but still a part of our common country.

Letters and contributions to be directed to Hon. Thos. G. Clemson, LL.D., Chairman of Comnittee, Pendleton, Anderson District, South Carolina. 

CHAPTER XIII. 


\section{DEFECTS IN OUR SYSTEM OF FARMING: SUGGES- TIONS FOR CORRECTING THEM.}

\section{An Adoress Delivered Before the Pendleton Faraiers' SOCIETY.}

BY DR. TAIT BUTLER, DIRECTOR OF THE FARMERS' institutes OF NORTH CAROLINA, FEBRUARY 13, 1908.

I shall devote my attention to a discussion of the following statement of what $\mathrm{I}$ deem unquestionable facts:

1. What is the matter with South Carolina agriculture? There is something radically wrong with the system of agriculture practiced by any State when the gross earnings of every agricultural worker averages less than $\$ 175$ per year.

2 . The great problem of those interested in the agricultural nplift of the State is: How can the earning capacity of the agricultural worker be raised to a point sufficient to indnce our hoys and girls and our laborers to stay on the farm?

3. My answer to this question is: We must have more agricultural knowledge, more farm machinery, more work stock, more general live stock husbandry.

4. More live stock is essential to greater soil fertility and a more economical marketing or utilization of the products of the soil.

5. More farm work stock and more farm machinery are essential to the full utilization of human labor.

6. Sufficient farm work stock will never be had until we breed it.

7. We will not breed sufficient farm work stock so long as we buy feed for live stock. 




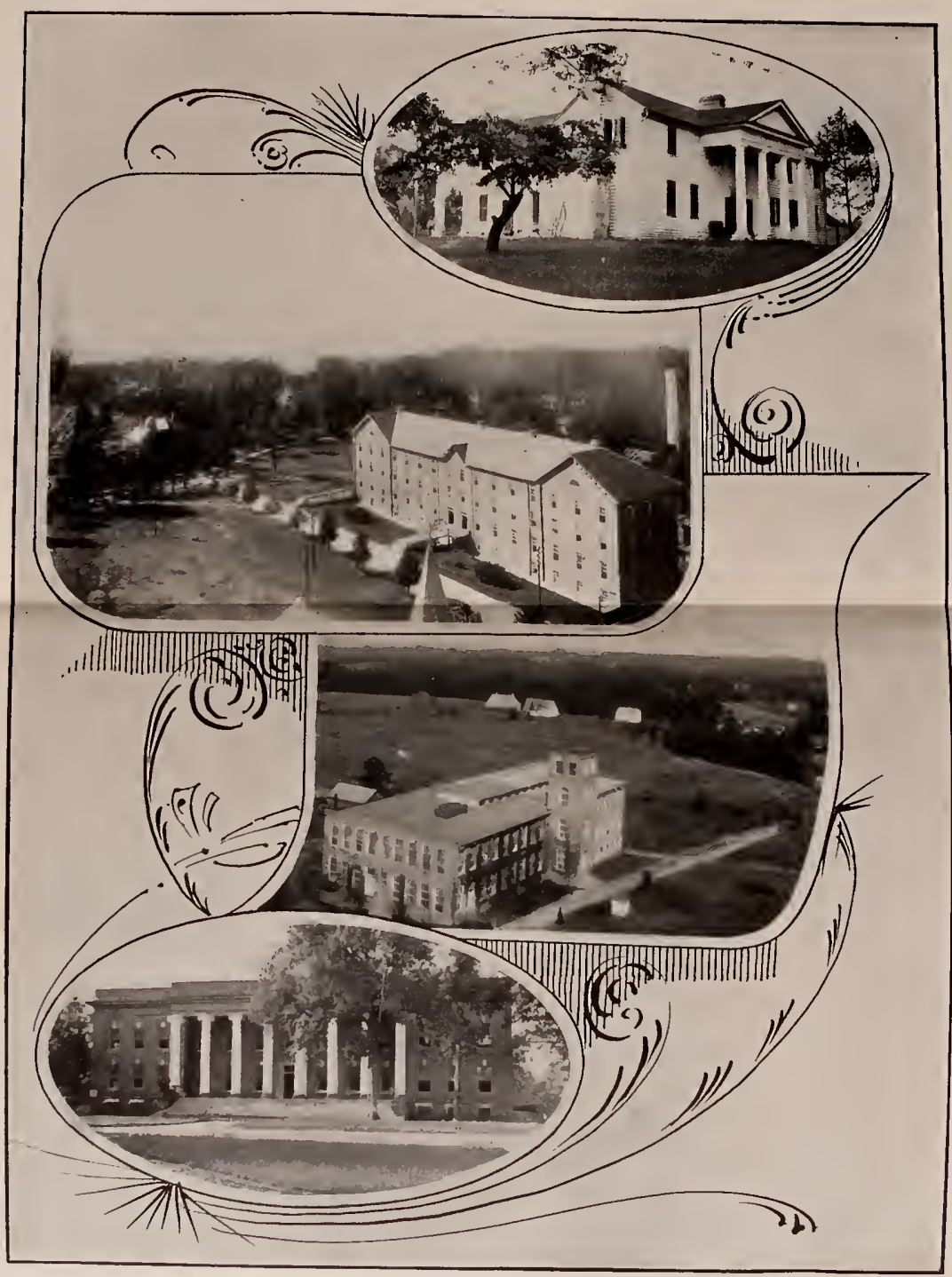

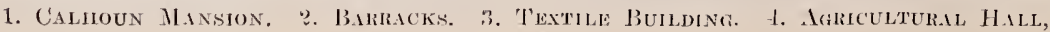
('LENASON ('OLLEGE, 

I have distributed among you sheets of paper on which is a comparison of certain phases of Iowa and South Carolina agriculture to which I invite your careful attention. I realize that comparisons are odious, but I make these solely for the purpose of graphically presenting the subject which I propose to discuss. My thirteen-year old boy-who has been studying the record of South Carolinians in the late unpleasantness-after reading these comparisons looked very seriously at me and asked: "Papa, are you going down to South Carolina and tell those people what you have written there?" I replied, "Yes, my son, that is my intention." After a short period of thoughtful silence he again said, "You had better not do it; for those people sure can fight, if they can't farm."

If it would not be less dangerous it certainly would be more pleasant to recount the glorious achievements of your famous men, for who could not find inspiration for his best efforts with a Calhoun or a Hampton as a subject, or we might easily find it discussing your delightful climate, natural resources and unsurpassed agricultural possibilities; or we might take peculiar satisfaction in paying our respectful homage to the courage and chivalry of your manhood and the beauty and refinement of your women; but the professional orators and politicians can do such tasks far better than I, so I shall not trespass on the field which they have ever cultivated so assiduously and successfully.

IIoreover, if we have not has too much of this palatable, if not overly nutritious mental food in the past, I feel quite certain we may depend upon our good friends mentioned, to supply our every need in the days to come.

I now. desire to call your special attention to certain facts stated on the sheets which have been distributed among you. Before considering these I may state that in estimating the number of agricultural workers all those, male and female, above ten years old who are engaged in any kind of agricultural pursuits were counted.

In calculating average earnings of agricultural workers the gross value of the products were used. which, of course, includes value of live stock products.

In estimating the value of fertilizers used per acre all improved land, no matter how used, was taken as the basis on which the calculation was made. 
Please not what is brought out by the first five points in our comparison; namely, that while Iowa has five times as much improved land; produces more than five times the value of agricultural products and each acre of improved land is worth nearly five times as much as that of South Carolina, she still has a less number of agricultural worker's. Iowa's improved lands produce only forty cents more per acre than the improved lands of South Carolina.

Now note, comparison six, what the foregoing statements mean: namely, that the average agricultural worker in Iowa earns more than five and one-half times that earned by the average agricultural worker in this State.

The remainder of the comparisons made are to show the reasons for the much greater earning capacity of the Iowa farmer over his brother in South Carolina.

He cultivates more than five and onc-half times as much land because he uses seven times the horses and mules and nineteen times the ralue of agricultural implements; while his expense for fertilizers is one seventy-eighth and he is assisted by cattle valued at 35 times, hogs valued at 33 times, dairies that produce 9 times and hens that produce 22 times as much as his South Carolina competitor who will not care for and feed live stock because forsooth it is too much trouble.

Now, my friends, we hear much about the boys and girls leaving the farms and of the scarcity of labor, but I tell you in all earnestness and sincerity that the boy who can not earn more than the average of $\$ 174$ per year ought to leave the farm or is not worth worrying about. Of course he will leave the farm, and I am here to approve his judgment and say God speed him.

Moreover, farm laborers will not stay on the farms, and those who have left will not return, unless they can earn more-unless you can pay them more-and they never can as long as there is only one horse and $\$ 14$ worth of agricultural implements for every two of them to use.

Moreover, you have not done your duty to those boys who have stayed on the farms, and after all that have left there are still a great many of your people living in the country. You have made great sacrifices to educate those who have left, to become doctors, lawyers and preachers, but what have you done for those who you know were going to stay on the farms? 
I have no quarrel with you because of what you have done for those boys that have gone to the cities and towns to supply fresh blood and energy, always so much needed there, but I ask, I insist that you do as well by the boys that are to farm. When you do the earning capacity of each agricultural worker in the State will be raised far above $\$ 1 \% 4$ per year.

As to the labor question, I know you will think me unorthodox, but I do not hesitate to declare that you already have too much labor! You have not more than one-fifth enough horses and mules; less than one-fifteenth the agricultural implements and not nearly enough improved land to profitably employ those you already have. With sufficient work stock and suitable machinery and implements the laborers now on your farms can be made to do four times what they now accomplish.

What is the solution? Educate the farmer and he will get more and better farm work stock and use more and better farm implements to cultivate more and better land. You need more live stock because it is also the essential basis of permanent and economical soil improvement. While your improved acres produce as much in value of products and much more per dollar of their market value than those of Iowa they ought and will produce four times as much under a proper system of agriculture involving the feeding of sufficient live stock.

The great need of our soils is more humus, more decaying organic-vegetable matter, and stable manure is the most economical method of supplying that material.

You need more live stock because no farm product that is suitable for feed for live stock ever ought to be put into the ground direct as a fertilizer. Such products have a double value--a fertilizer and a feeding value-and not more than twenty-five per cent. of the former need be lost in securing the latter.

I have now given you my answer to the question: What is the matter with South Carolina agriculture? I have also in a geireral way pointed out the remedy and now I propose to devote a little time to showing how the remedy may be secured and applied.

More live stock of necessity means more feed for live stock, and I therefore propose to consider briefly three by-products of South Carolina farms that are suitable for feeding live stock 
from which you do not now secure more than one-half their real value. I believe I can show that we already have and are wasting feed enough to keep double the live stock we now maintain.

The three by-products which I shall discuss are present on nearly every farm:

1. Cottonsced and cottonseed meal.

2. Corn stover.

3. Legume hays.

\section{CotTONONEED.}

Cottonseed has two values which the farmer should considera feeding value and a fertilizer value.

\section{Feeding Value.}

100 pounds of cottonseed-116 pounds of corn.

100 pounds of cottonseed meal -150 pounds of cottonseed.

100 pounds of cottonseed meal-175 pounds of corn.

Cottonseed has two values which the farmer should consider at $\$ 23$ per ton, and corn at 40c. per bushel, are about equally cheap for feeding purposes.

\section{Fertilizer VAlue.}

One ton of cottonseed contains:

75 pounds of ammonia at $61-2$ cents $\ldots \ldots \ldots \ldots \ldots 12.35$

26 pounds of phosphoric acid at $41-2$ cents $\ldots \ldots \ldots \ldots 1.1 \%$

24 pounds of potash at 5 cents $\ldots \ldots \ldots \ldots \ldots \ldots \ldots . .20$

Total ................... \$14.72

If cottonseed be fed to cattle and the manure saved with reasonable care, seventy-five per cent. of their original fertilizer value may be retained in the manure. In other words, when cottonseed are fed to cattle and the manure saved with reasonable care, a ton of cottonseed will give $\$ 11.04$ worth of manure, at the prices paid for mixed commercial fertilizer; that is, by feeding cottonseed to cattle, we can get per ton:

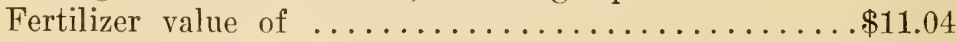
Feerling value of $\ldots \ldots \ldots \ldots \ldots \ldots \ldots \ldots \ldots \ldots \ldots$ 
Cottonseed Meal.

The fertilizer value of a ton of cottonseed meal analyzing 6.5 per cent. of nitrogen, 2.5 per cent. phosphoric acid and 1.5 per cent. potash is about:

130 pounds nitrogen at 20 cents $\ldots \ldots \ldots \ldots \ldots \ldots 26.00$

50 pounds phosphoric acid at $41-2$ cents $\ldots \ldots \ldots \ldots \ldots .2 .25$

30 pounds potash at 5 cents $\ldots \ldots \ldots \ldots \ldots \ldots \ldots . \ldots . \ldots . .50$

Total ...........................\$29.75

After feeding, three-fourths of this fertilizer value, or \$22.31, may be recovered in the manure when saved with reasonable care.

The feeding value as stated is $\$ 25$ a ton on a basis of 40 cents per bushel for corn; therefore the total farm value of a ton of cottonseed meal when fed is:

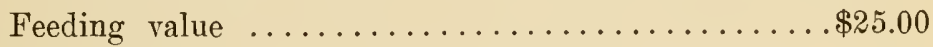
Manurial value $\ldots \ldots \ldots \ldots \ldots \ldots \ldots \ldots \ldots . \ldots 22.31$

Total $\ldots \ldots \ldots \ldots \ldots \ldots \ldots \ldots \ldots \ldots \ldots \ldots \ldots .31$

If it is claimed that these are too high values to put on cottonseed meal and cottonseed then I reply that either corn is not worth 40 cents per bushel to feed or you are paying too much for your commercial fertilizer.

\section{Corn Stover.}

As the corn crop is grown for food purposes only we should study its food value and harvest it so as to obtain the most from it. Taking the whole corn plant:

46 per cent. is ear (grain and cob).

54 per cent. is stover (stalk, blades and shucks).

But the animals are able to use as feed a larger percentage of the grain than of the stover, hence the feeding value of the corn plant is:

Ear 51 per cent.

Stover 49 per cent.

The greatest food value will be obtained from the plant when it is put into a silo and fed as silage.

When harvested for the grain or ears the whole plant should be cut and the stover used as feed for live stock. 
Pulling Corn Fodder is Expensive, Wasteful and Does Not Pay.

In experiments made to test the effect of pulling fodder on the yield of weighed shelled corn per acre the following results have been obtained:

Georgia-Pulled 23.9 bushels per acre; untouched $2 \% .3$ bushels per acre; loss 3.4 bushel per acre.

Florida-Pulled 28.2 bushels per acre; untouched 31.1 bushels per acre; loss 2.9 bushel per acre.

Mississippi-Stripped 35.5 bushels per acre; topped 29 bushels per acre; untouched 43.5 bushels per acre; loss 14.5 bushels per acre.

Alabama-(Two trials) ; loss 4 bushels per acre; average loss 6 bushels per acre.

\section{Fodder Obtained.}

Georgia-270 pounds per acre.

Florida-580 pounds per acre.

Mississippi-936 pounds per.acre (tops included).

Average-595 pounds per acre.

These figures indicate that on an average 6 bushels of shelled corn per acre when sacrificed for 595 pounds of fodder, and the labor and cost of pulling of the fodder thrown in.

The feeding value of six bushels of corn is nearly as great as 595 pounds of fodder, therefore the man who pulls fodder pays for the fodder obtained in loss of corn and has the pleasure he gets out of the delightful task of pulling fodder as his sole reward.

One acre of corn, yielding twenty-five bushels of shelled corn, will give an average of over one ton of stover (stalks, leaves and shucks). To harvest an acre and shuck the corn and shred the fodder costs from $\$ 3.00$ to $\$ 2.50$. A ton of stover is worth as much for feeding as 1,500 pounds of timothy hay bought from the North for $\$ 20.00$. This stover costs $\$ 3.00$ a ton to secure with the harvesting of the corn crop thrown in and if fed to steers they will pay $\$ 5.00$ a ton for it. At least they have paid me that much for it for the last three years. 
Thousands of tons of this valuable feed is allowed to waste in South Carolina each year while you buy thousands of tons of hay and pay from $\$ 20.00$ to $\$ 25.00$ a ton for it.

\section{Legume Hays.}

A ton of cowpea hay has a fertilizer value of about $\$ 12.00$. A ton of peavine hay is equal to 1,600 pounds of wheat bran for feeding purposes, but if we estimate its feeding value at $\$ 8$ per ton then when cowpea hay is fed and the manure saved with reasonable care we get a total value from one ton as follows:

Manurial value ........................\$ 9.00

Feed value $\ldots \ldots \ldots \ldots \ldots \ldots \ldots \ldots \ldots \ldots, 8.00$

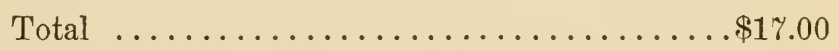

These values are all reasonable and within the bounds of practical operations but can not be obtained unless we feed better live stock, give that live stock better care and save the manure as its value justifies. 

CHAPTER XIY 


\section{CHAMPION CORN RAISERS OF THE WORLD.}

In 188\%, Z. Y. Drake, of Narlboro County, S. C., beat the world's record by producing 255 1-4 bushels of corn on one acre, winning a prize of $\$ 1,000$ offered by The American Agriculturist.

In 1906, J. A. Tindal, of Clarendon County, S. C., won the prize of that year open to the United States by growing 182 bushels of corn on one acre.

On account of their record in growing corn, the names of these gentlemen has been placed upon the roll of the Pendleton Farmers' Society as honorary members of the Society.

\section{CHAMPION RICE YIELD.}

In 1843 , Dr. O. R. Broyles grew 110 bushels of rice, weighing 43 3-4 pounds per bushel, on one acre on Eighteen Miles Creek, near Pendleton, supposed to beat the world's record at that date. 
CHAPTER XV. 


\title{
"GOOBER JACK," THE RUNAWAY SLAVE.
}

The Story of One of The Piedmont's Most Picturesque and Notorious Stane-time Characters.

\author{
BY COL. J. C. STRIBLING.
}

From The Charleston News and Courier, 1908.

(The story which follows is one of the many original articles which will appear in the fortheoming history of the Pendleton Farmers' Society, which was organized in 1815, and of which many of the most distinguished men in Sonth Carolina have been members. The gentlemen who are engaged in compiling this narrative have kindly permitted the exclusive publication in the Sunday News of this delightful narrative of ante-bellum days.)

Doubtless old "Goober Jack" was the most notorions character that ever lived among the slave-time negroes of the Piedmont section of South Carolina. His reputation among those of his race was similar to that of the heroic and daring Capt. Morgan among the Confederate soldiers; and a history of the Pendleton Farmer's' Society would be incomplete without a sketch of the old-time darkies and the amusing and peculiar traits of the famous runaway negro.

The name "Goober Jack" had been given to this particular darky on account of his especial fondness for pinders or peanuts. During his runaway or hiding out period Jack would dig goobers, or peanuts, at night from any peanut patch that might be conveniently situated and store the spoils of his foraging in hollow logs, trees or stumps for future use. At times, during the fal! or winter, the range of Goober Jack could be traced by the little heaps of goober hulls which could be found at the 
roots of hollow trees, old logs or stumps, or about the entrance to rocky caves, where the wild squirrels had broken into the darky's store and availed themselves of a liberal dividend from the accumulated earnings of common stock without the services of a receiver for the proper adjustment of the liquidation.

Goober Jack's resources for supplies, while "out in the woods," were numerous and blest with abundance. He had but to levy tribute upon any handy potato patch or goober field, milk the cows that in those days were stalled in open pens winter and summer, and in summer, upon the orchards, melon patches and roasting ear fields, all of which usually produced in abundance. And frequently, when the sweetening frosts of autumn had come, Jack often gathered the luscious persimmon and a 'possum from the same tree. And he was also an expert in the art of suppressing effectually the riotous noise which the fowls about the barnyard usually make when disturbed in the dark hours of the night by being suddenly pulled from the limb of a tree or from the fence or other convenient roosting places.

For a change Goober Jack would sometimes loiter among the shadows round the old-time kitchens in the back yards of the plantation homes, biding his time, when the cook should be going from the isolated kitchen to the dining room in the "big house," when he would make a sudden raid, lift out of the pot a cooked fowl, a ham or a pone of bread, and fly to the swamp with the speed of a fox.

Goober Jack's wardrobe was easily replenished from the farm house clothes line or the garden fence of the washerwoman in the same manner that he recruited his larder. For headgear Jack always wore a cap.made from a coonskin, with the tail of the coon which had furnished the hide hanging out from the top of his cone-shaped cap. As for shoes, he cared as little about that article of clothing as did the Indians who roamed through the territory in considerable bands.

Jack had an uncontrollable desire to roam at will and his master, the late Col. John T. Sloan, had become convinced that whipping neither kept Goober Jack at work nor sent him to the woods. He simply followed the bent of inclination. Just as the peculiar spirit moved him, Jack would come in and go to work, or he would leave the field and go to the woods. He seemed to obey only the alternate calls of a dual instinct, one 
turn of which was a call to the haunts of men, the other to the haunts of the beasts. And no one, not even Goober Jack himself, could tell with any degree of certainty whether he would be at work on his master's plantation the next week, or in the woods roaming from one plantation negro quarter to another at night, and many roguish and cunning darkies at that time made many expeditions of theft, which were credited to the account of Goober Jack.

All the children, both black and white, living within the limits of old Goober Jack's range and having a knowledge of his reputation, dreaded his appearance, as they might have dreaded some veritable black demon, although he never was known to do bodily harm to anyone.

When the children in charge of the "black mammy" became disobedient or unruly, all that was necessary to be done was to whisper into the child's ear: "Ef yo chillun don' be good, I'll tell ole Goober Jack whar yer sleeps to-night." Upon this warning the unruly chap never failed to line up and pay due respect to the commands of "black mammy," as every child dreaded a call from Goober Jack more than anything which could be threatened.

On one occasion Goober Jack having become so unruly and unreliable as a hand on the plantation, his owner concluded to sell him to a negro trader to be sent West, following the custom of those days to sell to these deporting traders all slaves who had become unmanageable, such negroes being carried away to the big plantations of the Mississippi country.

Goober Jack was accordingly sold and delivered to the negro trader at Pendleton Hotel, where the slave was chained and locked up for the night in a back room for safe keeping. During the night Goober Jack picked the chain lock and the door lock as well, and making his way to the saloon of the hotel, helped himself to the fine drinks and cigars to be found there. And when morning came, to the amazement of everyone, Goober Jack, feeling glorionsly mellow from his night among the decanters, was strutting back and forth along the front corridor of the hotel, with a big cigar in his mouth, taking the ease of a gentleman who might have been owner of a fine plantation and fifty negroes.

However, withont further trouble, Goober Jack agreed to go West, and he walked at will along with the trader's wagon, un- 
til he reached Mississippi, where he was sold. But about a week before the negro trader reached home again, Goober Jack was seen in the neighborhood of Pendleton. And he was soon at his old tricks once more, which he enjoyed as much as any common freedman of to-day enjoys the fulness of his liberty. In fact, Goober Jack was an interesting subject of conversation throughout the country, and was regarded as a huge joke at the expense of his owner, who, however, felt a degree of pride in the normal ownership of the most noted slave character in the Piedmont section of the State.

Some months after Goober Jack's return from his expedition to the Mississippi country some boys were fishing on the river at a point where Ravenel's bridge now stands, when one of the boys discovered some chicken feathers hanging on the briers and canes near the west bank of the river just above the spot which was used as a flat landing at that time. This discovery excited the curiosity of the boys, and immediately they slipped out of their clothes and waded into the stream to make an investigation. They took a back trail of feathers that were lodged among the shrubbery along the bank, thinking to locate what they believed to be the den of some big mink, where all the missing chicks of the neighborhood had gone to satisfy the appetites of Mr. Mink and his family. Some distance up stream, at a large canebrake, where the canes were leaning unusually low over the bank, the boys discovered a large hole which had been tunnelled into the ground at a right angle with the river. The boys now grew enthusiastic, believing they had discovered the home of a mammoth mink or coon family. The abundance of feathers strewn along the bank of the river and near the month of the den indicated that Mother Mink or Mrs. Coon had very recently gone through with a house cleaning operation which supplied the feathers for the trail that had led to the discovery of the den. One of the.boys was dispatched to the house of an overseer living not far away, and he soon returned with men, dogs, guns and tools with which to make an effectual attack upon the varmints which had been making such heavy raids upon their hen roosts. But no sooner had the men begun cleaning off the bank, preparatory to digging into the hole, than they became amazed at finding an old plank window shutter ingeniously constructed into a suitable cap for a ventilator shaft into the den 
below. This shutter had a number of auger holes bored in it, into which were twined a few pieces of laurel and cane twigs, the whole having been covered over with leaves in such a way as completely to hide the existence of the shaft. On the removal of this shutter Goober Jack's last hiding place was revealed, and out came the old runaway, like some huge rarmint in reality, to make a hasty compromise to go to work again for another period.

The discovery of this den cleared up the mystery of how Goober Jack had frequently lost the dogs which had peen put upon his trail at the river bank above. This usually occurred at the point where the railroad bridge now spans the stream. Jack would enter the water here and wade down stream to his den, thus destroying all scent of his trail. On some occasions Goober Jack succeeded in dodging the best-trained blood hounds of the country by floating down the river on a log or leaping upon the back of a work ox or an unbridled horse found grazing on the meadow and riding out of range of the hounds, turning the animal loose when he had no further use for him.

Perhaps the most ingenions ruse he ever put into practice was on an occasion when he was being hard pressed by a pair of the truest dogs in the whole country. Approaching the road just as an old-time closed coach, with a footman's or trunk seat behind, was passing, he kept himself concealed behind a tree until assured he conld not be seen by the occupants of the coach, when le crouched low and ran forward to the rear of the vehicle, climbed upon this rear seat and lay there quietly concealed. After riding about two miles out of range of the hounds he leaped from the coach again and made his way into the depths of the wild woods, back to his haunts, as free and about as happy as any denizen of the wilderness.

If there was one of Goober Jack's feats of ingeniousness more wonderful than the last, it was that to which he resorted at a rock quarry on Seneca River a little way above the present site of the Blue Ridge Railroad bridge, on the south side of the river near the old Treaty Oak on the Cherry farm, which marks the spot where Gen. Pickens made the treaty with the Indians.

The rock quarry referred to was walled in by a bluff, and the river formed a natural stockade which became useful as a sort of corral in which all the bad negroes of the country could be 
guarded and made to work in the quarries by day, while affording a means of preventing their escape at night. Goober Jack was among this gang, and while there he received one of his roaming irresistible calls. Not being able to swim or to pass the watchman on the land side. Goober Jack turned a wash pot over his head and deliberately entered the stream, literally wa?king across the bottom of the channel with ten feet of water above him, the imprisoned air in the inverted pot supplying the necessary oxygen to his lungs while making this perilons ard daring passage. Landing safely on the opposite side, Grobler Jack gave one of his peculiar blood-curdling, wild, panther-like screams, thus bidding farewell to the command of his masters and plunged into the canebrake with the utter familiarity of some wild thing of the woodland.

As a "leader" of songs at the old-time corn shuckings old Goober Jack was the king of them all. Goober Jack could assemble more men under his leadership to sing at contests by dividing the corn pile than any other darky.

Goober Jack kept a very peculiar cow horn to blow for his dogs that had a ringing, shrill sound, that reverberated over the hills and vales of the Piedmont region and could be distinguished from all other horns, and was heard many miles beyond, where the sound of ordinary dog horns died away.

About dusk in the evening of some big "corn shucking" Goober Jack would mount upon the top of a tree on the highest hill in the vicinity, blowing his horn to the notes that told all the negro men in the range of many miles that a corn shucking and feast were in store at a nearby plantation. Almost every negro quarter within the sound of Goober Jack's horn would be deserted by the men at once to rally around old Goober Jack and march for miles to the plantation where the "husking bee" was on, singing corn songs that echoed over the hills as they approached the corn pile.

These old-time corn piles were usually piled in long ridge-like shape on the hard ground in the open near the corn cribs, and contained anywhere from a few hundred to several thousand bushels.

The younger generation of South Carolinians that never saw a real corn shucking of ye olden times, in ante-bellum days, has missed one of the most enjoyable annual festivities in our State's history. 
About the time when it appeared that the bulk of the negroes had arrived from the nearby plantation the "boss" or foreman of the plantation proceeded to "divide the pile" of corn by placing a fence rail across the middle and allowing the two "leaders of the gangs" to choose their men for winning the jug of whisky or fat turkey that was to go to the gang that cleaned up their pile of corn first.

Now, the real hard work and tussle to a finish was on in earnest; such fun and high singing has never been witnessed since.

Old Goober Jack and his opponent each mounted and paced the top of the ridge of their respective half of the corn pile, leading the favorite festive corn songs, which was answered with a loud, strong chorus from every hand around the corn pile, and nerving every hand to do his best, tearing away the shucks from the ears like madmen fighting to win or die.

The antics of old Goober Jack while pacing the top of the corn pile amid the flying ears of clean corn as they passed or hit him, was like nature's own opera house. The leaders of these corn songs would mimic the cock's crow, the hooting owl, the bellowing of a bull, the whip-poor-will, the mocking bird or the killdee. When mocking the killdee Goober Tack would place a large corn shuck about his hip pocket for a tail of the killdee that he planted while he pranced up and down the corn pile bowing and swinging his body in imitation that would shame the killdee, calling out:

"Never see a killdee but what he was in the motion."

Chorus by all hands:

"Oh, round de corn, Sally," etc.

Another favorite song, or chant, was like this:

"De little bee suck de blossom,

De big bee make de honey.

De nigger make de cotton,

And de white folks tote de money."

The chorus, by all hands, being:

"Gin corn, nigger,

Gin corn, I tell yer."

After finishing shucking the corn, then comes the "round up," "carrying the boss" on the shoulders of several big negrnes, marching all around and through "the big house," setting the boss 
in his chair at the head of the long table, loaded down with roasted whole pigs, fowls, stacks of sweet potatoes and pumpkin pies, "knee high to a nigger."

After all had feasted then came in the old-time nigger fiddlers and then came dancing by some of the select young men and women, which wound up the festivities in time for all hands to get back home "by the crack of day in the morning." 

CHAPTER XVI. 


\section{THE BLACK GHOST OF THE ROCKY BRANCH OR THE SLAVE-TIME POSSUM HUNTER.}

BY J. C. STRIBLING.

Among the foothills, vales and spurs of the Blue Ridge Mountains, better known as the "Piedmont Region," is to be found the greatest variety of natural food for the opossum, raccoon, rabbit and squirrel. In the dense forests that cover the rivulets of the deep ravines with arching boughs or shelter the banks of the larger streams, and along the hedgerows of the cultivated fields, abound the wild summer grapes, the crab apple, the winter grape that hangs upon the vine until far into the spring, the luscious muscadine, the cherry, the summer and winter huckleberry, persimmon, gooseberry and dogwood berry, together with the toothsome paw-paw and the large variety of wild nuts. And all of this makes the Piedmont Region the natural paradise of the nocturnal huntsman. The fat and greasy opossum is the prime object of the night-time hunter who begins in early autumn to lay in his supply of resinous pine pieces for making the necessary torch lights when the hunting time came, an abundant supply being ever near at hand. And when "de fros' ripen de possum" in October the hunving season begins and it ends not until the coming of the whip-poor-will in March.

The negro population of the Piedmont Section, during the slave days was almost, if not quite, equal in numbers to the whites; and with these blacks owned in small numbers, as a rule, throughout the section, the slaves were brought into closer personal contact with the whites their owners, and in consequence received better attention and care and gained a higher form of civilization than their less fortunate, half-barbaric brethren of the large rice plantation of the low country. Still, most of these old slave-time darkeys still cling to their native beliefs and superstitions, among them being the fear of ghosts, the power of the graverard rabbit's foot, the cat of nine lives and many other hoodoo practices. But, notwithstanding these fears, the 
darkeys preferred hunting, and traveling about the country at night rather than in daytime; and no sportsman of the turf or the pavilion enjoys his sport more than did these "possum and coon hunters" in their primitive way. And indeed, the "possum hunt" meant to them not only sport but profit, for the luxury of a feast "possum an' 'tater" was something to be looked forward to with the keenest relish; and not the greatest "chef" of the land could excel the "ol" black mammy" in the preparation of such a luxurious feast. The simplicity of the feast, served in the log cabin by the old black woman in her clean straight frock of homespun, and with a spotless white handkerchief tied about her head, bore a charm that whetted the most languid appetite to a pitch of gluttonous inclination.

The possum hunt is nature's sport by nature's man, witl nature's means and in nature's way; and no turfman ever bestowed more care or kindness upon the most valuable racer of his stable than did these old-time darkeys upon their hunting dogs. And there is always one dog in the pack that leads the chase, another of the cold nose (one especially enabled to scent a cold trail). another that can whip any raccoon or strong dog, and still another that never fails to "tell the truth at the tree," which means that where he bays at the root of a tree, the game is sure to be among the branches.

And this brings us to our story. One corn shucking season in the later days of the old slave time, the report was spread among the negroes throughout the neighborhood that a "great black ghost" had been met on several occasions by the huntsmen who visited the "Rocky Branch" section; and various were the descriptions of the big black ghost, some declaring that the creature had stood erect like a man, with long shaggy hair covering its body, and with a pair of great gleaming eyes that shone like balls of liquid fire in the darkness. Others who had come in contact with the mysterious thing avowed that it resembled a tremendous black bear with horns on its head and other monstrous protuberances from its body; while "Old Rance," who prided himself upon his daring, and sniffed at the fear which he declared belonged only to "dem common buckra niggers w'at ain' been raised 'mongs' 'telligent whi'folk an' b'lebe' 'en ghos's an' sich like" and who was considered the greatest nocturnal huntsman of them all, declared: 
'Dat ghos', 'e des beat all dem animile yo eber see. W'en yer fust see 'im, 'e stan' up on 'e two hin' laig des like a man, an' 'e hab horn on de back o' 'e haid, an' long whiskers on 'e chin des like de buckra man; an' fo' yer can see how 'e do it, 'e done turn to de bar and des come down on de groun' 'whop' wid all 'e fo' feet-den, boss, fo' de Lawd, yo neber see dog run so seence yer been bo'n. Eber dog tuck 'e tail 'twix' 'e laig an' come tearin' roun' hin' me for 'tection. Now, Boss, it ain' nuttin oncommon for dese yere puppies to run f'om common t'ings; but w'een ole Rock an' Troup an' Blaze all pull out an' come tearin' pas' me, dis nigger 'cluded dar was some'n dang'ous ober dar, so I des say to me foot, 'carry de body out o' dese woods;' an' sho nuf, des as 'um sta't off good, de torch done blow smack out-an' dis nigger done run ober eb'ry saplin'-log, an' rock in dem woods fo' 'e git home an' de nex' mawnin' 'um had fever in de haid, whilst dese ole laig so stiff, dis nigger ain' scursely walk dese fo' days."

Thinking that perhaps a real bear had strayed down from the mountains, we made arrangements with old Uncle Henry, one of the bravest of the colored possum hunters to take some of the boys with him on his next hunt in the haunted region, in order that he might keep guard over the ghost, should he find it, while he dispatched a messenger home for me. And accordingly, only a few nights had passed when I was aroused from sleep by loud calling at my door:

"Boss! Boss! do come, git yo double barrel gun and fotch ole Bull, I'se got de ole black ghos' treed in de big yellow poplar ober on de Rock Branch."

In a short while, my friend "Joe," from the city, and I, together with old "Bull," the large yard dog, were on the way toward the Rock Branch to engage in what we supposed would be a bear fight. Our guns were well charged, and old Bull, who had the reputation of being the king of all the beasts on the plantation on account of his having, on one occasion, brought down a vicious bull at the bidding of his master, was frisky and eager for the fray.

On reaching the top of a high hill about a mile from home, old Henry called a momentary halt.

"Dar!" he exclaimed, "Boss, des lis'n at dat fine music!" 
From far away in the distance came the howl of the dogs, deep-roiced and ringing clearly on the night air. My friend Joe listened a moment, then in a tone of disgust, remarked:

"Well, I can't hear any music or anything else for the howling of those darned dogs."

Old Henry looked up with a look of mingled surprise and resentment on his face. "Dat's it, Boss, dat am de fines' music eber yo hear. Des lis'n to old Troup, 'e soun' de bass, an' Marsh de counter, Sam de tenor, whilst Venus carry de tribble high as de moon."

Then he gave one loud whoop which rang away among. the hills and vales for miles, stimulating the entire pack of hunting dogs to renewed vigor in baying the game still far over the hills.

We now pushed forward until we reached a deep, boggy ravine which we were to cross by "cooning" a fallen tree trunk. (Cooning was the act of crawling on all-fours along the fallen tree.) Joe undertook to walk it upright, but when about midway, old Bull, who in his eagerness for the fray, had broken away from Henry, came rushing between Joe's legs, upsetting him and sending him head foremost into the bog below.

Uncle Henry, who by this time had come to regard Joe as being a little "off," on account of his want of appreciation for fine possum hound music, rather reluctantly began to assist in removing the mud from Joe's eyes and mouth, as the latter came up from the bog. While thus engaged, Joe's false teeth accidently came out of his mouth and fell at old Henry's feet. The latter stood back aghast at this frightful state of affairs. And in his deep distress he exclaimed:

"Boss, bettah sen' for Doctor quick. Dis yere mon mout' done broke all to pieces, 'e jaw bone an' teet' done drop out on de groun'."

On receiving the information that these teeth were not natural but made by hand, the old darkey muttered half to himself:

"Dese yere city buckra am de curiousest human 'um eber see, walkin' 'bout yere live wid 'e mout' full ob home-made teet,"

Without further hindrance we soon reached the haunted spot to find the pack of dogs keeping up an incessant, deafening noise, baying and springing into the den, only to come out faster than they went in, snapping and growling as they went 
and yelping and snarling as they came. High up a tree near by were two negro boys who all the while had been encouraging the dogs to keep up the baying while Henry had gone for help. A little persuasion brought the boys down to assist; and one of them held the large torch light, the other held the end of old Bull's chain, and Henry held his collar, the powerful dog being now almost unmanageable, surging here and there and standing erect on his hind feet showing his full length to be as tall almost as old Henry himself, and evincing a ferocity equal to that of any ghost or bear as the case might prove.

After placing Joe a little above the tree on the opposite side of the ravine, I was about ready to station myself just below and a little to the right of him; when, suddenly, old Bull, having dragged his keeper a little too uncomfortably near the big opening in the poplar tree, was released; and Henry snatched the torch from the other boy's hand.

At this juncture, I must confess, a case of genuine "Buck Ague" began to creep over me. Buck ague, as known among huntsmen, is that feeling that presses on just before the game advances within gun shot. At the same moment, old Bull, with all the hounds close behind him, plunged into the den, and such a mêlée followed as was sufficient to raise the hair on end. There were the sounds of baying and yelping, snarling and snapping of sharp teeth, the rattling of a chain and the confusion of a most ferocious encounter inside of the hollow tree; and above the din arose a thrilling squall strangely human aud yet animal that pierced our ears with its agonized shrillness-and out of the opening came a confusion of yelling dogs, old Bull, the big white dog-and some tremendous black object, all clinched in such close quarters that it was impossible to get any idea of the true form of the game, ghost or animal. Over and over, and down the hill all roiled together; in the meantime upsetting old Henry and extinguishing the torch, leaving all in utter darkness. And at the exciting moment when the torch went out, the loud report of a gun rang out on my right.

When the light was renewed, the seene which presented itselif to our view was ludicrous in the extreme. Down in the bed of the ravine below, old Bull was standing over the dead body of a huge black billy goat. Hard by lay one of old Henry's best dogs killed by a misdirected shot from Joe's gun. Perched 
high in the bending tops of two slim saplings, with their heels higher than their heads, the two negro boys were clinging, lizard fashion, to the branches, with their big eyes glaring down upon the confusion below. But the most ludicrous situation of all was that of old Henry himself who, with arms clasped round the trunk of a tree, and with legs locked below only a few inches from the ground, was holding on for dear life as though forty feet from the ground and out of all danger of the Black Ghost. 

CHAPTER XVII. 


\title{
CURRENT NEWS NOTES DURING THE EARLIER DAYS OF THE SOCIETY.
}

\section{NOTICE.}

The undersigned Commissioners appointed last session of the Legislature, to aid and assist the State Engineer, are now ready to accept proposals, or contract for the erecting of a brick Gaol in the village of Pendleton: and will continue to accept them until May, next. Persons wishing to contract will apply at Mr. Samuel Cherry's store, where the elevation plans and specifications will be exhibited for inspection, and where all proposals will be received sealed. It will be essentially necessary where proposals are forwarded that the securities be named in the letter.

\author{
Samuel Cherry, \\ Francis Burt, \\ Elam Sharpe, \\ Commissioners.
}

March 24, 1819.

Pendleton Messenger, Wednesday, April 7, 1819.

The African Slaves, sixty-three in number, seized by the United States, sold at Milledgeville (Georgia ) on the 17th inst. for forty-one thousand seven hundred and ten dollars cash: the highest went off at $\$ 890$, the lowest, except one at $\$ 380-\$ 662$ round.

(Pendleton Messenger, Wednesday, September 9, 1818). 


\section{A SUCCESSFUL WOLF HUNT.}

The farmers of this place have for several years past been very much troubled by wolves, destroying their sheep, which have been seen several times but which could never be taken.

On the night of Monday the $2 d$ inst., they killed three sheep belonging to James C. Griffin, Esq. The next day he collected five or six of his neighbors, and after dinner they surrounded the thicket where the wolves had been heard howling before daylight near where the sheep were killed-they soon started a large he-wolf which after running around the thicket several times attempted to pass where Mr. Griffin was standing, who shot him -he ran a little distance back into the thicket and after a little resistance was killed by the dogs. The party then returned to the village, but having observed tracks of different size, decided they would search the same woods again; in a short time they started a large she-wolf, who ran around the thicket familiar to the former and was killed by Mr. Jno. Miller, Jr., within 150 yards of the same place- both within a mile of the court house. To those acquainted with the ways of the wolf, the circumstances attending this affair are very singular, and a similar occurrence is not remembered by the oldest hunters.

Pendleton Messenger, June 10, 1818. 


\section{PENDLETON FARMERS' SOCIETY.}

Resolved that the resolution offering the following premiums at the Regular Meeting of the Pendleton Farmers' Society, in September next, be published:

For the best calf, bull or heifer, raised in this district. Ten dollars.

For the best Ram Lamb raised in this district. Five dollars.

For the best piece of cotton eloth, not less than twenty yards manufactured in the district. Ten dollars.

For the best piece of woolen cloth, not less than ten yards, (all wool). Ten dollars.

Resolved that the candidates for the calves and sheep, to be awarded at the next meeting of the Society, must exhibit a satisfactory certificate of their age, to the examining committee, and that the certificate of a member shall be sufficient.

On motion ordered that the above resolution be published in the Messenger, together with the resolution offering the premiums passed last September.

R. Anderson,

Secretary.

August 13, 1818.

Pendleton Messenger, Wednesday, September 2, 1818.

\section{RAN AWAY.}

From the subscriber on the 1st inst., Walter Adair an apprentice to the shoemaker trade. He is about nineteen years of age, about five foot and six inches high and of a swarthy complexion.

All persons are warned against harboring or employing him as the utmost rigor of the law will be enforced against any person who may do so.

Six cents will be paid for delivering the said Walter Adair to me, or for lodging him in the gaol at Pendleton, but no expenses paid.

August 3, 1818.

Thomas Richards. Pendleton Messenger, Angust 5, 1818. 


\section{PROPHECY.}

In anecdotes of the life of Bishop Watson, lately published, we meet with the following prediction made by the bishop in 1804:

The death of a single prince in any part of Europe, remarkable either for wisdom or folly, renders political conjectures of $\mathrm{fu}$ ture contingencies so extremely uncertain, that I seldom indulged myself in forming them: yet it seems to me that it is probable that Europe will soon be divided between three powers, France, Austria, and Russia, and in half a century between two, France and Russia : and that America will become the greatest naval power on the globe and will be replenished by migrations of oppressed and discontented people from every part of Europe.

Pendleton Messenger, Wednesday, August 26, 1818.

\section{NOTICE.}

The employment of an agent or attorney is not necessary in any claim against the Government. It is most generally attended with expense and sometime with actual loss.

Claims will be promptly settled when the accounts and vouchers with which they are connected are transmitted to the proper office.

Money will be transmitted whenever a receipt for the sum due or, where the amount is not ascertained a receipt in blank shall be forwarded to the Treasury Department.

Military patents and certificates of military pensions will be transmitted in the same manner, whenever the necessary vouchers are forwarded to the proper office.

Jomn Quincy Adams.

WM. H. CraWford.

J. C. CaLHOUN.

B. W. Crowninshield.

Washington City, May 27, 1818.

Pendleton Messenger, June 24, 1818. 
At the Anniversary Meeting of the Pendleton Farmers' Society, the following gentlemen were elected officers for the following year:

!as. L. North, Esq., President.

Jas. C. Griffin, Esq., Vice-President.

Col. Robert Anderson, Secretary and Treasurer.

John T. Lewis, Corresponding Secretary.

Pendleton Gazette, June 1\%, 1818.

At a stated meeting of the Pendleton Farmers' Society, held at the Pendleton Court House, on the 14th inst., the following resolutions were adopted:

On motion, Resolved that notice be given in the Pendleton Messenger, that the second Thursday of June next, will be the anniversary of the Pendleton Farmers' Society, and that general attendance of members are requested on that occasion.

On motion, Resolved that a committee be appointed to request Mr. Thomas Lorton to provide a dinner for the members of the Pendleton Farmers' Society, on the day of their next anniversary, and that all the members intending to join in the dinner, be requested to leave their name with Mr. Lorton, on or before the anniversary.

Pendleton Messenger, June 15, 1818.

R. Anderson, Secy. 


\section{PENDLETON FARMERS' SOCIETY.}

From Pendleton Messenger, October 20, 1843.

The Farmers' Society of Pendleton met as usual on their anniversary the second Thursday in October. Various business was transacted, and officers elected for ensuing year. Agreeably to previous request, an address was made by Mr. Ruffin, of Virginia, which, on motion was ordered to be published in the Pendleton Messenger. A public dinner having been prepared, the Society dined together in Mr. Cherry's long room. The purely agricultural toasts below were given on the occasion. Mr. Seabrook after the toast of the committee was received, replied in a few appropriate and handsomely expressed remarks.

We regret exceedingly, that a complimentary toast to Mr. Ruffin, and his toast to South Carolina, in reply, being furnished us on a small slip of paper, have been accidentally mislaid. Possibly some others that were given have shared their fate.

Some of the reports made to the Society, the award of premiums \&c., will probably appear in our next. Mr. Ruffin's address appears to-day.

\section{TOASTS.}

The President being called on for a toast said, I propose gentlemen the memory of a distinguished agriculturalists, who has fallen since our last anniversary meeting, the Hon. James M. Garnett.

By the committee-Our Guest: the Hon. Whitemarsh B. Seabrook, President of the Agricultural Society of South Carolina, devoted to the improvement of the whole State. We welcome him among the farmers of the up country.

By Hon. W. B. Seabrook--The Cause of Agriculture throughout the world, and succeess to those who by precept or example sustain it. 
By Hon. John C. Calhoun-Agriculture: The most important, but the most oppressed branch of industry.

By C. C. Pinckney-The Pursuit of Agriculture: The most useful, the most honorable, the most ennobling of all human pursuits; adapted to every class in every clime.

By Dr. F. W. Symmes-Pendleton Agriculture: To be improved and made profitable only by economy and manure.

By F. Burt, Esq.-The Agricultural Survey of the State: The first recognition of the farming interest by our Legislative authorities.

By Hon. R. F. Simpson-Sonth Carolina: If behind her sisters in anything it is in Agriculture. Present exertions, would seem to indicate that she will not be long behind even in that.

By Col. E. Harleston--The Farmers of Pendleton: They have now had it demonstrated to them the resources of the district, may they use them with zeal and energy.

By T. G. Clemson-In the absence of Marl, permit me to propose to the citizens of Pendleton, a more familiar acquaintance with the effects of the applieation of those soils which contain Potash, Soda, and Magnesia.

By Capt. John Maxwell-The man who made 12B of wheat per acre on poor mountain land, and 30 gallons of corn stalk syrup to the acre.

By Dr. O. R. Broyles--Dry land ditching, and a judicious rotation of crops, the first and the most important by far in the practice of Agriculture, and yet they are almost entirely neglected in this district.

By Rev. A. Fuller-The Agricultural Interest: One which is identical in every part of the Union.

By B. F. Sloan-The Agricultural Interest: The only great interest that has neither asked nor received the protection of the general Government.

By A. H. Seabrook-Commerce, Manufactures, and Agriculture; but the greatest of these is Agriculture.

By J. O. Lewis-Marl: May it add as much energy to the men as it has fertility, to the soil of South Carolina. 
Mr. E. B. Benson is appointed Secretary and Treasurer, and W. H. D. Gaillard, Corresponding Secretary, of the Pendleton Farmers' Society; to supply the vacancies occasioned by the much lamented death of our late Secretary and Treasurer, and also, Corresponding Secretary, J. W. Warley, until our next regular meeting, which will be on the first Thursday in April; when an election will take place to fill those vacancies.

Geo. Seaborn; President.

December 16, 1843.

The Society will award the following premiums at their Hall in the village of Pendleton on Friday, October 13, 1843:

For the best two acres of corn grown in the district on upland, provided the produce exceeds fifty bushels per acre. . . . . . . . . . . . . . . . . . \$10.00

For the best two acres of corn grown in the district on low ground, provided it be not less than seventy-five bushels per acre.................. \$10.00

For the largest produce of wheat grown in the district, on two acres, provided the amount per acre is not less than twenty bushels .$\$ 10.00$

The land on which the above crops are grown to be laid off in a square, or oblong form whose sides are not to exceed their length more than double.

For the best quarter of an acre of millet .......\$ 3.00

For the largest produce of provender of good quality, from one acre, provided the amount to be not less than 3 tons well cured . . . . . . . . . . . $\$ 10.00$

For the largest quantity of rough rice grown in the district on one acre, to be of good quality and not less than fifty bushels ............... \$10.00

For the best specimen of corn stalk sugar not less than ten pounds .................. \$10.00 For the specimen of molasses, not less than five gallons. $\$ 5.00$ For the best pound of sewing silk, made in the district. $\$ 3.00$ For the best pair of silk half-hose $\ldots \ldots \ldots \ldots \ldots \ldots 1.00$ 
For the best bull calf of an improred breed under two years old .................... \$ 5.00

For the best boar of an improved breed, under 12 months old ........................... \$ 5.00

For the best ram of an improved breed ........\$ 5.00

For the best sow of an improved breed, under twelve months old ..................\$ 5.00

For the best ewe of an improved breed .........\$5.00 The stock to be owned in the district.

J. W. WARLEY, Seeretary P. F. S.

Pendleton, January 20, 1843.

COMMITTEES FOR 1843.

Committee on Grain-T. M. Sloan, John Maxwell, Panl Hamilton.

Committee on Provender--J. V. Shanklin, B. F. Sloan, J. O. Lewis.

Committee on Corn-stalk Sugar and Molasses-J. S. Lorton, T. R. Cherry, A. C. Pickens.

Committee on Silk-D. S. Taylor, A. H. Seabrook, F. Burt.

Committee on Cattle-R. F. Simpson, Wm. Sloan, A. F. Lewis.

Committee on Hogs and Sheep-Geo. Seaborn, J. T. Sloan, O. R. Broyles.

On Discretionary Premiums-T. J. Pickens, Wm. Steele, Colin Campbell.

Committee to prepare Premiums for 1844-Jas. Stuart, E. Harleston, R. A. Maxwell.

Committee on Sales at Auction--J. W. Warley, W. L. Jenkins. Alfred Fuller.

Committee to provide dinner on ensuing anniversary-W. H. D. Gaillard, A. S. Gibbes, E. B. Benson.

September 1, 1843.

J. W. WArley, Seeretary P. F. S. 


\section{LET THE BOYS HAVE FUN.}

The Labor School referred to below was organized and in working order about the year 1325, and was perhaps the first attempt at an Agricultural College in this country.

Editors Sun.: We often, of a winters night take our pipe and think over some of the pranks and fun of boyhood days, and laugh to think of them. Serenty-five of the worst hoys in South Carolina were sent to a manual labor school. Rev. J. L. Kennedy was the principal; noted for his great ability to manage and educate bad boys. At the sonnd of the trumpet every morning at daylight these bad boys assembled in the recitation room for prayers. They would shoot pop-corn at each other, and carry on mischief in such a manner, that Mr. Kennedy had to pray with his eyes open to keep them quiet. We have tried to keep posted in the history of those seventy-five bad boys, and as far as we know all succeeded in life, and many of them made eminent divines, lawyers, physicians, merchants, planters and politicians, with two exceptions-one did a mean trick at school, which followed him through life, and one made a drunken, murderous gambler. I know you like short articles, and will only give one among a thousand pranks played on each other: Some of the big boys were musicians, performed on violin, flute, banjo, \&c. This school was located four miles from Pendleton, S. C., a town noted for its pretty girls. The big boys were in the habit of going on Saturday nights to town to serenade the girls and would not let the little boys go with them, so they concluded to play a trick on them in revenge. A creek ran across the road a mile from school leading to town. The big boys, dressed in linen clothes, had a nice time. While they were gone, the little boys procured shovels and buckets, dragged and toted black mud from the swamp, spread it nicely over 
the steep little hill running down to the creek, and stretching a well-rope tightly across it, awaited the result. As the serenading party returned late in the dark night, the little fellows raised a frightful yell and the big boys started to rum and were tripped and piled up in a heap in the black mud.

The prank showed energy and pluck. A boy who goes with his head down, moping about like a lousy calf, is not apt to rise in the world when a man.

Written by the late JoHn B. Benson.

Hartwell Sun, May 23, 187\%. 
CHAPTER XVIII. 
THE

\section{CONSTITUTION}

AND

\section{BY-LAWS}

OF THE

\section{PENDI,ETON FARMERS' SOCIETY,}

TOGETHER WITH THE

Letters and Papers

WHICH HATE BEEN READ BEFORE THE SOCIETY,

AT ITS VARIOUS MEETINGS.

Constitution of 'The Pendeeton Farmeris' Society.

As Published in 1820.

Aпт. 1. The Society shall be styled, The Pendleton Farmers' Society.

Arr. 2. The objects of the Society shall be the promotion and improvement of agriculture and rural affairs. Their attention shall be confined to these objects.

ART. 3. A President, Vice-President, Secretary and Treasurer, and a Corresponding Secretary, shall be annually electerl, by a majority of the members present, at the anniversary of the Society, the second Thursday of June in each year. The persons elected to continue in office one year, and until a new election takes place. In case of vacancy by death, resignation 
or otherwise, the same may be supplied by a new election, made at any stated meeting of the Society; the person elected to serve the remainder of the year.

ART. 4. At the meetings of the Society, the President shall exercise all the usual duties of that office. All motions shall be addressed to him, and on all questions he shall collect and declare the votes. He shall have power to call special meetings, by giving public notice of six days. In his absence the VicePresident shall exercise the same powers. A quorum for business shall consist of the President or Vice-President, and at least four members.

ART. 5. The Treasurer and Secretary shall keep the hooks and papers of the Society, and the accounts regularly stated. At the meeting previous to the anniversary, he shall produce his accounts fairly stated, books, and papers, and deliver them to his successor, on the anniversary, or to the order of the Society.

ART. 6. The Corresponding Secretary shall have in sharge all letters addressed to the Society, and answer the same under their direction, which letters and answers he shall keep regularly filed.

ART. 7. The stated meetings of the Society shall be on the second Thursday of each month of each year.

ART. 8. The members of the Society shall be distinguished into resident, honorary, and contributing members.

Resident members shall consist of persons residing within the district. All members of Agricultural Societies in other states and countries, with whom this society shall correspond, and all persons of this state and of other states and countries, who shall be elected for the purpose, shall be honorary members; and are hereby invited to assist at the meetings, whenever they come within the district. Strangers who desire to be present, as auditors, may be introduced by a resident member.

Honorary contributing members, are of the description hereafter mentioned. Every citizen contributing and paying into 
the hands of the Treasurer a sum not less than ten dollars, may be elected, agreeably to the rules, an honorary member, without regard to place of residence. Those who thus laudably cnable the Society to extend its usefulness, and promote its objects, are invited to assist at its meetings. They will be styled hoilorary contributing members.

ART. 9. New members, whether resident or honorary, shall be elected by ballot, in their absence; application on their behalf shall be made to the Society at a stated meeting previous to their election. Three negatives shall be sufficient to reject a member proposed.

Arт. 10. For the purpose of defraying the necessary expenses of the Society, for premiums and prizes, books on agriculture, improved instruments of farming and other important objects, every member shall annually pay into the hands of the Treasurer, on the anniversary, the sum of one dollar and a half, at the close of which said meeting, the Treasurer elect shall lay before the Society a list of the members, specifying who have and who have not paid their contributions. No part of the Society's funds shall be disposed of except at a stated meeting, of which notice shall have been given at the stated meeting previous.

ART. 11. New rules or alterations shall be proposed, and the proposal entered on the minutes, at the stated meeting preceding the anniversary, and may then be made by not less than two thirds of the members present. 
Rules and By-Laws for tire Governalent of time

Farmers' Society.

As Published in 1820.

Rule 1. At all meetings of the Society, the President shall take the chair, and call the members to order, at 11 o'clock.

2. Every member wishing to move a resolution, shall reduce it to writing, and address the chair standing. No resolution is to be open for discussion until seconded, but the mover may state reasons for any preliminary observations, not touching the merits of his resolution, before it is seconded.

3. No member shall be allowed to speak more than twice on any one subject, without permission of the Society.

4. In all cases every member shall rise and address the chair uncovered; the member first up shall have the precedence. The President shall confine the attention of the Society to the member speaking, and not suffer him to be interrupted in any manner whatever.

5. In cases of more than ordinary interest, the Society may go into a committee of the whole, on the requisition of any five members; when the President shall nominate a chairman, who shall preserve the same order and decorum, and cause the same rules of debate to be observed, with the exception of the third rule.

6. The previous question may be moved and seconded at any state of the debate, in committee of the whole, and shall be in the following words: "Shall the main question be now put?" Should the committee decide in the affirmative, the main question shall be put immediately, without debate. 
7. Whenever a resolution has been disposed of by a vote of the Society, it shall not be in order to move that, or a similar resolution during the meeting, without a vote of the Society to re-consider.

8. Every member of the Society who shall violate any of these rules, or who shall not conduct himself with propriety and decorum, both of language and manner, shall be called to order by the President or Chairman, and if necessary, be directed to resume his seat.

9. In cases of gross, scandalous, violent, ungentlemanly conduct, the Society may expel a member. The resolution for this purpose, must be signed by two members, who will hand it silently to the President, who is bound not to disclose their names, and who is to request the member to withdraw. After debate, the member named shall be introduced, and informed by the President of the substance of the charges, and required to make his defence after he returns, either at the moment, or at the next stated meeting. When a vote is taken, it shall be by ballot, and it shall require two thirds of the meeting, which shall consist of at least one fourth of the resident members, to expel a member.

10. All applications for admission to this Society, and all resignations, must be made in writing; and any resident members leaving the district, shall be entitled to continue honorary members.

11. The resident officiating Ministers of the Gospel of this district, shall be entitled to be resident members of this Society, free of contribution.

12. All members, and all persons who shall hereafter become members of this Society, shall sign the constitution and these rules.

James C. Griffin, President.

Josias D. Gaillard, Vice-President.

Robert ANDERson, Secretary \& Treasurer. Joseph V. Shanklin, Corresponding Sec. 
Gen. Thomas Pinckney . . . . . St. James Santee. Hon. William Lowndes . . . . . . Charleston.

C. C. Pinckney, Jr. . . . . . . . . . . Do.

R. S. Izard, Esq. . . . . . . . . . . . Do.

J. R. Pringle, Esq. . . . . . . . . . . Do.

Dr. J. Noble . . . . . . . . . . . . Do.

Gen. D. E. Huger : . . . . . . . . . Do.

Hon. J. C. Calhoun . . . . . Washington C. $\overline{i t y}$. Col. J. B. Ion . . . . . . . . . St. James Santee. Col. L. J. Alston . . . . . St. Stephens, Alabama. Rev. Dr. Waddell . . . . . . . Athens, Georgia. Gen. Jolnn Blassingame. . . . . . Greenville. D. P. Hillhouse . . . . . Washington, Georgia. Dr. Isaac Auld . . . . . . . . Edisto Island. Dr. C. M. Reese . . . . . . . . Philadelphia.

\section{RESIDENT MEMBERS.}

\section{5.}

Thomas Pinckney, Jr. John L. North, Andrew Pickens, Benjamin Smith, John Miller, sen., Charles Gaillard, John E. Calhoun, J. T. Lewis, Thomas L. Dart, J. B. Earle, C. W. Miller, Samuel Cherry, John Taylor, Tames C. Griffin,
Robert Anderson,

William Hunter, Benjamin Du Pre, sen.,

Joseph Grisham,

L. M. Gregor,

Samuel Earle,

Richard Harrison,

Patrick Norris,

J. C. Kilpatrick, Joseph B. Earle, T. W. Farrar, Thomas Stribling, John Green, Tosias D. Gaillard, 
1816.

John Maxwell,

B. F. Perry,

William Hubbart,

E. B. Benson,

George Reese, sen.,

George W. Liddell,

J. B. Perry,

John Martin,

T. Farrar,

W. R. Davis,

William Gaston,

Joseph Reed,

Elam Sharpe,

D. Sloan, Jr.

Samuel Warren,

Leonard Simpson,

Major Lewis,

Samuel Taylor.

$181 \%$

William Steele,

James Lawrence,

Francis Burr,

John Hunter,

W. S. Adair,

William Taylor,

William Anderson,

Joseph Mitchell,

Thomas Lorton, Rev. James Hillhourse,

Benjamin Dickson,

Richard Lewis,

J. T. Whitefield,

J. B. Hammond,

John Holbert,

Robert Lemon.

\section{8.}

John Hall,

David Cherry,

John Gaillard,

Theodore Gaillard.

Charles Story, M'Kenzie Collins, George Taylor,
Samuel Gassaway,

R. A. Maxwell,

J. P. Lewis,

F. W. Symmes,

George Reese, Jr.

Joseph Whitner,
James Faris, William Oliver, James O. Lewis, Thomas Sloan, Henry $\mathrm{M}^{\prime}$ Crary, David K. Hamilton. 


\section{Address to the Farmers' Society.}

Permit me, gentlemen, briefly to call your attention to the objects of this institution; to present in a few words its vast importance to our country generally, and to this section of it in particular; and I know not how I can more plainly and forcibly express myself, than by stating the situation of other sections of our happy country, which formerly were in our present condition, but which are now advanced a century before us in agricultural knowledge. A learned and judicious farmer of our sister state of Pennsylvania, describes the state of agriculture after the conclusion of the former American war, as wretched in the extreme. Their lands were exhausted by a constant succession of grain crops, and then abandoned to weeds, as worthless. New land was cleared, and the same miserable system pursued. Man and beast suffered alike, as the forage for the latter was supplied from the scanty crops of the farmer, or the poor animals fed on dry straw and the scanty pickings of the fields. Animal life was barely sustained through the winter, and that with difficulty. Does this sad picture present to your minds no home reflections? Does not a striking similarity of situation present itself? From this unfortunate state of daily struggle for support, they were relieved by a few intelligent men; who, united in a society for agricultural improvement, such as we now form, have, by their judgment, zeal, and agricultural knowledge, diffused so much instruction to the intelligent farmer, as to convert his barren land into fertile soil, and to substitute the wine and oil of abundance, for the miseries of poverty and starvation.

This happy change, however, was not effected in a day. They had to contend with the prejudices of ignorance, and the oisstinate and blind perseverance in bad habits of those who pretended to agricultural skill. They pursued their carecr with unwearied step, undismayed by the difficulties which presented themselves, till they finally placed the agricultural interests of their country on a footing seldom equalled and not exceeded by any on this continent. 
Such, gentlemen, is the successful career of the Philadelphia Society for the Promotion of Agriculture, aided by similar societies in Pennsylvania. And who will not say that they merit the lasting gratitude of their country? We are accustomed to consider men of a different character as great and illustrious. The actions of Cæsar and of Scipio; of Marlboro' and Eugene, or in latter times, of Bonaparte and Blucher, entitle them, in modern phrase, to be called great. But these men derived this title from their proficiency in destroying their fellow men. Their fame, like the pestiferous fumes of the charnel house, arises from the gore of mortals like themselves. It is steeped in blood, and is accompanied by the groans and shricks of millions. Far different, and how far preferable, is the character of the scientific and industrious agriculturist. He is the benefactor of his fellow men: his talents and his labors are devoted to the support and happiness of mankind. They make man intelligent and independent. They teach him to derive his wealth and respectability from the fruitful bosom which nature's God assigned us for this purpose: and his efforts, unlike those of the horrible traffickers in human blood, confer a lasting benefit, not only on his contemporaries, but on posterity.

We may justly conclude then, that as war and warriors are the curses, peace and agriculture are the blessings of the world.

In a national point of view, we have every inducement that can operate on a well organized mind, to stimulate our exertions. Living under the liappiest and freest government in the civilized world; protected by mild laws, in the enjoyment of every right not incompatible with the equal rights of others; it is the duty of allegiance: it is the duty of gratitude: it is that duty, which love of comntry imperiously dictates, that every citizen should contribute his utmost efforts, to place his beloved country on the pinnacle of national prosperity. Our citizens, of all professions, shonld unite in this glorious effort, and it is confidently believed that the effort will insure its success. In other pursuits our citizens have established and sustained a national character, not exceeded in the old world. Our statesmen are decidedly superior. In the learned professions of law and physic, we exhibit a splendid specimen of American intel- 
lect. Our naval heroes, by their valor and skill, and honorable humanity, have extorted the plaudits of an admiring world; and our armies have lately proved themselves superior to the boasted discipline of Europe. Even in agriculture, some of our sister states have attained a proficiency highly honorable to themselves, and promotive of their permanent wealth and prosperity. Why then are we so far behind them? Why does not their patriotic example influence our conduct? Are we made of inferior materials? Are we not fostered by the genial warmth of the same political atmosphere? Or has our wayward fortune thrown us on a sterile rock, incapable of improvement? None of these obstacles exist. Our district has emerged from the infancy of its settlement, while our agricultural knowledge is yet in the cradle. Let me not be told that this torpor proceeds from local causes: That our numerous water courses are obstructed by rocks, and that we shall find no vent for our increased productions. The answer is obvious. The superficial barriers which nature has thrown in our way, only to stimulate our exertions, are not removed, simply because their removal has not yet been necessary. But once increase your productions; double them, quadruple them, and they will not be dammed up at home; but like our swollen streams, they will burst with irresistible impetuosity through the rocks and barriers which impede their course to market. This is the natural course of events. The connection between this district and the commercial sections of our State will be facilitated, and we shall obtain in exchange for our flour, our corn, our tobacco, and our beef and pork, such articles as our necessities may require, at reduced prices.

Do we want the evidence and authority of the best and wisest men in our republic, as to the importance of agricultural knowledge to our country? It is at hand. Washington, acknowledged by an admiring world to be the greatest man of the age, "the first in war, the first in peace, and the first in the hearts of his countrymen," was, himself, an agriculturist. He inculcated by his precepts, and enforced by his example, the principles and practice of agriculture, as intimately connected with the welfare of that country to which he has left so many proofs 
of his devotion. Mr. Jefferson, on this subject, has ably seconded the example of his predecessor. He has been personally instrumental in establishing agricultural societies, and has given us much valuable information. It is needless to multiply examples, almost every distinguished citizen of our country, however they may have differed on other points, have united in opinion, that a successful system of agriculture is the basis of our prosperity; that it is the foundation of commerce; that it strengthens the federal bond of union: that it increases the actual value of our country; that it enlightens our citizens, as to its numerous blessings; that it diffuses knowledge, and thereby strengthens a good govermment, "which is never in danger, while a free people are well informed." If these opinions of our best men be correct, (and what sceptic can hesitate to believe them,) does it not behoove us to assist in this fair and goodly work, whose object is so all-important, whose means are so much within our reach. But I deem it useless to address a further argument to you, gentlemen, on an interesting subject, on which the existence, and wealth, and permanent prosperity of our country so essentially depends; I will merely suggest a few measures, which appear to me to be calculated to promote the object of our infant but already respectable institution.

I propose, in the first place, that our Corresponding Secretary be directed to open a correspondence with the Philadelphia Society for the Promotion of Agriculture, informing them of our institution, and its objects, inviting their assistance and information, as to the means of procuring the best samples of seeds and grain, particularly wheat, the time and mode of sowing it, the preparation of the soil, and its culture generally. The public spirited character of that Society, warrants the belicf that they will receive the communication with pleasure.

I recommend to your consideration, the payment in advance of our first annual subscription, to afford the means of defraying any little expenses incident to this proposition.

I propose for your consideration, the expediency of opening a correspondence with Mr. Vaughan, of Philadelphia, requesting him to furnish the Society with the Memoirs of the Philadelphia, and other similar Societies in the Northern States, and gen- 
erally such other books, on Agricultural subjects, as our funds will enable us to obtain. The well known philanthropic character of this gentleman leares no doubt that he will execute this commission with pleasure.

As most agricultural experiments and improvements require time to execute them, I propose for your consideration, the expediency of offering a premium for the best field of wheat, not less than four acres, which must be ploughed at least twice, and harrowed in, the wheat not sown among corn; the grain to be thrashed out, accurately measured, and a fair sample produced to the Society, at their stated meeting, the fourth Thursday of July, 1816 ; certificates of the preparation of the ground and measurement of the wheat to accompany the sample. Public notice of this premium should be immediately inserted in the Pendleton Messenger, to which should be prefixed, a short statement of our Society and its objects; and inviting the assistance of literary, philosophical, and agricultural men. The premium should be a silver cup, of the value of-_-dollars, with a suitable inscription.

To these observations and propositions, permit me to add the expression of my gratitude, for the unmerited honor of the presiding chair, to which nothing indeed could have entitled me, but your partiality, and zealous interest in the important object of this Society. I indulge, however, a fervent hope, that by the blessings of Providence, a star may rise in the west, whose brilliant effulgence mav illumine a midnight path, and attracting others within its orbit, may finally shed the happiest rays of light on the destinies of our beloved country.

Thomas Pinckney, JR. President of the Farmers' Society. .T. T. Lewis, Es?., Corresponding Secretary. 
On the Superiority of the Egyptian Over the Common OAT.

BY THE FIRST PRESIDENT OF THE SOCIETY.

Pendleton, July 12, 1815.

SIR-Having heard some farmers declare their opinions in preference of the common oat, to the Egyptian oat, I take the liberty of stating to the Society, the result of my experience this year, as to these two kinds of oats.

About the 15th of March, I sowed ten acres, one half with Egyptian oats, and the other half with the common black oats. The same quantity of seed, and the same culture was used, and they were both sowed in the same field. The Egyptian oats always appeared more vigorous and thriving; on the 10th of June, the whole field was eared out, and shortly after, I observed that the common oat was very much smutted, almost one ear in ten, while I could not find one single smutted ear in the Egyptian oats. I also observed that not more than two or three stems rose from one plant of the common oats, while five or six were common from the other; and the general appearance of the field warrants the opinion that double the quantity of the Egyptian oats will be reaped.

The common oats were cradled on the $3 \mathrm{~d}$ of this month, since which, the continued rains have obliged me to let the large oats stand, and though they are over ripe, I do not observe that they lodge at all, though one of my neighbors informed me his common oats were down. The straw of the large oat is stronger and larger, and more valuable therefore for manure.

The Egyptian oat is a winter grain, and should be sown under furrow in September, when they will furnish a good winter pasture for sheep, without much injury, if they are taken off early. They litter very much when sown early, and spread on the ground, which the common oat does not, and its not being liable to smut is a great advantage. I have sown them many years, and do not recollect ever to have seen them smutted. It is a 
good practice to let the oats intended for seed remain a few days after the others are cradled, as it is probable that unripe and damp seed, which will get mouldy, may be one cause of the smut in oats. It is highly advantageous to cut the rest of the crop some time before they are ripe, while the stalk is yet green; if well cured, their value as fodder is thereby doubled.

The same results as to these two kinds of oats, may not arise, if sown by different farmers, in different fields, and in different years; a better or a worse season or soil, may cause an improper conclusion to be drawn. The fair way is to sow them perfect similarity of circumstances under which they were at the same time, in the same field, and in the same way. The oats sown in my field, leaves no doubt in my mind, of the great superiority of the Egyptian oat.

I have only to add that the soil of the field is tolerably good upland, some clayey loam, with a substratum of stiff red clay. Although the subject of this communication may not be thought very important, yet I think if farmers generally would favor the Society with their experiments on every agricultural subject, a mass of information would be collected, from which might be selected a most useful and practical system of husbandry.

I am sir, very respectfully,

Your obedient servant, Thomas Pinckney, Jr.

J. T. Lewis, EsQ., Corresponding Secretary. 
ON WHTAT.

BY JOHN L. NORTH, ESQ.

\section{JULY 7, 1815.}

Sin-In consequence of the very serious damages that wheat crops have for several years past sustained from rust, and of the heavy loss necessarily experienced by the farmer, I have been induced to turn my attention to that subject, and I now communicate to the society a few observations, not so much however with the hope of offering any thing new or interesting, as of encouraging gentlemen to similar atternpts.

Of all the diseases to which wheat is subject, I know of no one so rapid in its progress or so fatal in its effects, as rust. The moment it seizes on a plant, all vegetation ceases: in a few days its leaves and stalks become dry and useless, and the grain eventually tums out to be light and worthless. Farmers, and indeed men of science, appear to be but little acquainted with the cause or nature of this disease, and still less with the remedy proper for it. The variety of opinions that have been offered on the subject, (some plausible indeed, but none perfectly satisfactory) is a proof of this fact. Dr. Darwin supposes rust to be a fungus, similar to mildew, which resembles certain kinds of liverwort, and grows beneath the leaves of plants already diseased, and conjectures that greater light and ventila-* tion may prevent or destroy it. Whether this hypothesis has ever found any advocates among men of science, I have never been able to learn; but I believe it to be unsupported by the experience of any respectable farmer, either in Europe or this country. My own is directly opposed to it. I have sowed wheat on lands somewhat worn, but still in good heart, and also on the very first quality high lands, and have always noticed those parts where it was thin, and of course completely exposed to the operation of both light and ventilation, to be greatly injured, whilst others differently situated, have escaped entirely, or been little affected. The same or very similar results, have been remarked by others for several years past, and as far as I 
know, without any material variation. Mr. Segur conjectures mildew to be the cause of rust. $\mathrm{He}$ describes mildew as a disease of plants, consisting of a thick, clammy, sweetish juice, that is supposed to exhale from or descend on the leaves and blossoms of plants. This juice is said to be of a sharp corrosive nature, and by its acrimony, to prevent the circulation of sap. Others again ascribe it to honey dew, which is in its nature and effects very like mildew; and a few, I believe, to the action of cold, which bursts the sap vessels, or to inmumerable insects. The last of these opinions seems now, however, to be generally abandoned; for the most accurate and patient examination, by means of microscopical glasses, does not lend it even the color of support. Without considering further the varying, and in many instances, contradictory opinions of writers on this subject, I proceed to mention the issue of several experiments made by me with the view of finding some preventive for this disease; and also of others, which, though not máde by me, nevertheless came under my observation, and thence draw a few conclusions.

In November, 1812, I sowed nine acres of stiff creek low grounds in wheat; npwards of a bnshel was put to the acre, and ploughed in with two horses. When it had only its two first leaves, the cold weather set in, and continued with undiminished severity for several weeks. During that time, we had a fall of snow; it was not deep enough to do good, indeed it rather did harm. One or two days after the snow disappeared, I examined my wheat, I found it, as to growth, but little improved; its appearance red, and otherwise unhealthy. Through the winter it remained nearly stationary; as the spring advanced, however, it pushed forward rapidly, and promised well. About the time rust generally makes its appearance, I heard of some fields in my neighborhood being overrun with it. This induced me to examine my crop a second time, when I found it to be injured only where it was thin, or backward, or where it was lightly manured with ashes. But these spots were also backward. I harvested at the usual time. My wheat, under all these disadvantages, was fair and usually plump. It yielded considerably more to the acre than my neighbors; and weighed 
sixty-six pounds to the bushel. The spring was late; the nights and days alternately hot and cold.

The succeeding fall I had a very fine piece of high land sowed down in wheat; about the same quantity was put to the acre as on the preceding year. It was plonghed in with a single horse, but well, the land being in capital tilth. In the fore part of the spring, which was opcn, my wheat became luxuriant. On the 16th and 1\%th of April, the forward shoots were filled in the hose by frost. The under shoots then came forward. The whole field was almost totally destroyed by rust. Another field at some distance from the creek, and which suffered but little from frost, escaped almost without damage. These fields were sowed about the same time and by the same hand; the quantity of seed to the acre the same. The wheat on the creek was most backward.

Last year I sowed a twelve acre field in wheat, allowing nine bushels to the whole, or three pecks to the acre. It was ploughed in with two horses. Throngh the winter and spring its growth was inconsiderable. It was generally much injured by rust. On examination I found that those spots which were shaded or thin, or where a quantity of ashes had been left, (some log heaps having been burnt on the field) were the most damaged. The spring more backward than the two preceding. Frost occurred as late as the 22d of May. On the adjoining farm, six bushels of wheat were put on between three and four acres of land, some of which had been upwards of twenty years under cultivation. It was sowed rather later than mine, but came up about the same time. The only part affected was rather thin. The grain is good, and the crop promises to be abundant.

To these statements I might add many others; but I deem them sufficient for my purpose. I cannot, however, deny myself the satisfaction of relating a fact, which, though it has no material bearing on the subject of rust, yet shews that the practice of thin sowing is discountenanced by some able farmers, on the score of profit. In Switzerland, one of the best agriculturists usually sowed three bushels of wheat to the acre, first, however, dressing that quantity of ground with light loads of manure. The produce, one year with another was sixty bushels 
to the acre, which left, after deducting the expenses of seed, rent, tythes, labor, \&c. a clear gain of twelve bushels and thirty bundles of straw per acre. I am particular in mentioning straw, because it is everywhere, but in this country, considered to be of the very first importance. It is the source whence the greatest quantity of manure is derived, and without manure there can be no good farming.

From the above statements I deduce the following inferences:

1st. That rust, whatever may be its nature, arises chiefly from the alternate action of heat and cold, on plants that are thin; or from whatever cause, unreasonably backward.

$2 d$. That deep ploughing, which increases the pasture or food of plants, and thick sowing, which preserves a more equal temperature, are the best preventives of this disease.

I am sir, your obedient servant, John North.

J. T. Lewis, Esq., Corresponding Secretary. 


\section{ON PEa Hay.}

BY JOHN L. NOR'TH, ESQ., CHAIRMAN OF A COMMIT'EE.

SePteMrber 11, 1815.

Sir-It seems to be conceded on all hands that an ally to Indian corn, on which we have heretofore relied for the support of our horses and stock during the winter and spring, has become absolutely indispensable, for it can no longer be concealed, that under our present wretched system of husbandry, this grain exhausts very much; and whilst it yields every succeeding year, a more straitened supply, returns less offal to the earth than any other we grow. By some unaccountable oversight, the stalks which are in other states carefully husbanded, and turned to good account, both as an article of food and manure, are with us, suffered to remain through the winter exposed to the influence of sun, air and frost, or else a half starved drove of cattle is turned in upon them to glean a scanty subsistence. To the exhaustion that lands necessarily experience in the production of every kind of white grain, is thus added waste, and the serious damages that kneading them into mortar, invariably occasions. In this poached state, all the benefit they may have derived from frost is entirely lost; and they are likewise prevented from imbibing those particles from the atmosphere, which constitute so essential a portion of the food of plants. For remedying these evils, which were so severely felt in the diminished product of our crops, and increased poverty of our farms. many of us had recourse to small grain, which it was confidently hoped would at once ameliorate the soil, and supply all deficiencies. Among these, wheat and rye had the preference; but experience, so far from justifying our choice, has compelled us to admit that they impoverish much more than Indian corn; that they yield less to the acre, and that their litter is not to be compared, either in quantity or quality, with that of Indian corn, whilst the food they furnish, is also less substantial. With the same view, onts have been tried, but owing perhaps, to the small quantity of seed sown to the acre, they have proved even more in- 
jurious and less productive than either wheat or rye. Notwithstanding, however, the ill success of these experiments, we ought not to be discouraged, since other crops may do for us, what we had too inconsiderately expected from those of small grain. As promising a more favorable issue, we earnestly rerommend leguminous crops, particularly peas, which will answer the double purpose of shading and opening the soil. T'hey give besides an excellent food, and the hay made of the rines is superior to any we have ever tried. We have known several horses to be kept throngh the winter, in excellent order, upon what was gathered from a corn field of small extent. It is no material objection to them, that they are difficult to cure, for if that be the case, they are also not easily spoiled. As another auxiliary, let us bring to your notice, oats, which ought, however, to be sowed at the rate of between four and five bushels to the acre, and cut before they shoot the ear. Oats have been found to do well at the northward, on lands not differing in quality from our own. It is, however, to be distinctly understood, that they are to be grown in this manner, only on farms which have no meadows. To these may be added Guinea corn, which succeeds well here, and affords a greater quantity of green food for soiling, than any plan I am acquainted with. It will besides enable us to abandon pasturing our fields, which is perhaps the most fruitful source of their poverty. Chicory and manglewurtzel or the white beet may also be tried. The former of these is spoken highly of in England, and may answer well here. It is greedily eaten by horses and sheep. Like Guinea corn, it may be cut several times through the summer. Above all we recommend meadows. 'To these only can we look for effectual relief from the incumbrances under which our corn cribs daily groan; and for a constant supply of manure, upon which, it cannot be too often repeated, all economical farming must be bottomed. We have not noticed cabbages, potatoes, 
parsnips, turnips, carrots, \&c., because we do not think they will answer. Most of them have not done well at the northward, and from the trials we have made of them, they will do worse here. As coming within the subject of economy, we recommend that all manures be diligently saved and applied; that weeds be carefully extirpated; and that farms should never be burthened with supernumerary horses or cattle.

I am, \&c.,

Jonn L. North, Chairman.

J. T. Lewis, Eso., Corresponding Secretary. 
ON SHeEp.

BY JOHN L. NORTH, ESQ.

SIR-As merino sheep are daily becoming more important as well to individuals as to the community, it will not, I hope, be unacceptable to the Society, to have a few remarks on their introduction into some of the countries of Europe; on the practicability of acclimating them here; and also on their great superiority over every other kind now in our State. For a long time it was the prevalent opinion, that merino sheep degenerated in form and size, as well as in fineness of fleece, everywhere except in Spain; for it was generally believed that their frequent migrations from the flat lands, to the mountains, (to which agriculture was almost entirely sacrificed,) but more especially that some peculiarity in the soil and climate of that country, was essential to their greatest perfection in these respects. From this opinion, we accordingly find no deviation, until the year 1722, when their introduction into Sweden was made a national concern, a premium of 25 per cent. being allowed by the government "on the value of the wool to the grower." The climate of Sweden is regarded as less friendly to sheep than that of any other improved portion of Europe, both on account of the heat and shortness of its summers, and the length and severity of its winters; nevertheless they have not degenerated, even there, although Sweden possesses upwards of 100,000 merinoes of the pure blood, and nearly a century passed since they were originally introduced. A circumstance so extraordinary as this, it might have been expected would not have been suffered to pass without improvenent, much less without notice: yet for a considerable time, (surh is the power of prejudice) no attempts were made by other countries to secure this valuable breed. At length in 1786, Louis XIV. after having, by numerous experiments, ascertained that they would do equally well there, imported into France, under the care of Spanish shepherds, four hundred rams and ewes, which were by permission of the then sovereign king, selected from the best Spanish flocks. 
These so far from degenerating, on the contrary, have actually improved in every respect; for M. Gilbert, one of the members of the national institute, asserts "that they do not yield in any circumstance, to the most beautiful in point of size, form and strength, or in the fineness, length, softness, strength, and abundance of the fleece." He ards, "the manufacturers and dealers in wool, who came in numbers to Rambouillet this year, (1796) to purchase, unanimously agreed to this fact, at the very time they were combining to keep down the price." This statement is confirmed by M. Tesaire \& Huzard, and likewise by the duke of Bedford, who says, "that he found the sheep of Rambouillet of a size he was unprepared to expect, and that still the wool preserved its original purity." He also states that "samples of the wool taken when the sheep first arrived, and at various periods, since that time, were examined by him, with all possible accuracy, and evidently declared a progressive improvement." Col. Humphries, of Connecticut, also mentions in his letter to the Agricultural Society, of Massachusetts, that the national flock of France, gave double as much as those of Spain, and still their wool retained its original fineness." In England where they have lately been carried, they have also ardently undergone a change for the better; for Doctor Parry insists, "from his own experience, that the wool of his upland ewes, in the fourth generation, was injured when he put to them a full blood Spanish ram." Encouraged by the success of these and other experiments, and believing from circumstances, that even the condition of the imported breed of Europe might be meliorated in this countrv. in 1792, Mr Livingston, then our ambassador in France, purchased several ewes and a ram, and shipped them for the United States. These were picked from the so justly celebrated Rambonillet flock; yet Mr. Livingston declares them to be inferior in every point, to those of his own raising, but particularly in the quality of the wool. "It is certain," says a writer on the subject of merinoes. "that Mr. Caldwell, of New Jersey, in all his enterprising purchases, from the late importations of Spanish sheep, has never met with any equal in appearance, fineness of fleece, or length of pile, to those of his own raising. from his original flock." Their easy acclimation at the northward, and the great profit derived from them, joined 
to the persuasion that they would thrive equally well in our climate, induced several merchants to import a few of the mixed breed from the Northern States, and some full breed Spanish merinoes into Charleston. A few of both descriptions were disposed of there. I have seen, in different parts of the state, many of the lambs of these, most of them were superior in form and size to the parent stock, and such of their fleeces as I have noticed, were decidedly finer, without adding other proofs of their progressive improvement, and of course, of the practicability of acclimating them in the Southern, as well as the Northern States. I come now to the principal object of this communication, which is to show that they are much more advantageous to the farmer. The sheep of this state in particular, may be divided into three or four different kinds, but I shall only notice those that are attended to on account of their wool. The most remarkable of these, indeed the only one worthy of observation, is that which resembles the Southdown sheep of England, which are thus described by lacock: "It has no horns, its legs and face are grey, its head and upper part of the neck very thick, the pile planted very closely on the pelt, the fleeces very unequal, that of the back differs considerably from the produce of the sides and shoulders, and the brush becomes suddenly very coarse, the pile not uniform, and frequently contains a number of coarse and long hairs, which prove hurtful to the cloth." Their fleeces, it is understood commonly weigh from two to three pounds, and sell in England at about 42 cents the pound. The following description of merino sheep is from Mr. Livingston's book, on that subject. "The race varies greatly in size and beauty, in different parts of Spain. It is commonly rather smaller than the middle size sheep of America. The body is compact, the legs short, the head long, the forehead arched. The ram generally (but not invariably) carries very large spiral horns, has a fine eye and a -bold step. The ewes have generally no horns. The wool of these sheep is so much finer and softer than the common wool, as to bear no sort of comparison with it; it is twisted and drawn together like a corkscrew; its length is generally about three inches, but when drawn out, it will stretch to nearly donble that length. 
The wool is, when cleansed, extremely white, yet on the sheep it appears of a yellowish or dirty brown color owing to the closeness of the coat, and the condensation of the perspiration on the extremities of the fleece. The wool commonly covers a great part of the head, and descends to the hoof of the hind feet, particularly in young sheep: it is also much more greasy than the wool of other sheep. The skin is of a fine carnation red and very thin." It is stated, on good authority, that merino wool has sold in England at upwards of $25 \mathrm{~s}$. sterling the pound; at the northward it readily commands two dollars. It has already been remarked, that "the wool of these sheep is so much finer and softer than that of common sheep, as to bear no sort of comparison with it;" but this is not the only circumstance in which they claim a superiority; they also yield more wool in proportion to their size or weight of carcase. To settle this point, five common sheep were weighed on Mr. Livingston's farm, their average weight was found to be $82 \mathrm{lbs} .6 \mathrm{oz}$., the average weight of each fleece $4 \mathrm{lbs} .4 \mathrm{oz}$., so that these sheep gave one pound of wool to every $20 \mathrm{lbs}$. of carcase. With the same view twelve half and three-fourth blood ewes were weighed, the average weight of each was $64 \mathrm{lbs}$, that of the fleece $5 \mathrm{lbs}$. $14 \mathrm{oz}$. which is one pound of wool to every $101-2 \mathrm{lbs}$. of carcase. And my own observation convinces me that, great as this difference appears to be, it is not exaggerated. I last year sheared sixteen common sheep, seven of which were three years old wethers of fine size; their united fleeces gave me only 32 lbs. or $2 \mathrm{lbs}$. to each fleece, whilst four half bloods, of the common size, one of which was shorn the fall before, vielded me $20 \mathrm{lbs}$. or 5 lbs. to every sheep. Mr. Arbuthnot, of Bath, (formerly a woollen manufacturer) has for several years tried the Spanish cross with the Wiltshire breed, nearly trebling the wool in quantity, and improving it extremely in quality. "The carcases," he observes, "are reduced in size, but improved in mould, and their disposition to fatten increased." Now if we suppose the wool of each sort to be worth fifty cents per pound, and their keep through the winter one dollars fifty cents, there will then be a loss of fifty cents on every common fleece, estimating these at two pounds each, which is believed to be a fair estimate; but in the case of mixed merinoes, a clear gain of fifty cents, their 
fleeces weighing double as much as those of common sheep. In Mr. Livingston's treatise on sheep, to which I am indebted for most of the information this paper contains, and which I earnestly recommend to the attentive perusal of every farmer, a calculation of a similar nature will be found; but it is much more satisfactory, being more particular. He there proves that on 201 common fleeces, the grower will sustain a loss of six dollars and three cents, or three cents per fleece, whilst the same number of mixed merino fleeces will afford a net profit of 765 dollars; and, if the value of the sheep themselves, and of their lambs, be taken into consicleration, there will then be a difference of upwards of 2,000 dollars, in favor of the merinoes. Another advantage, which must not be overlooked is, as has been already mentioned, that they are much more easily kept, and of course less expensive to the farmer. Every animal with which I am acquainted, I will venture to assert, will be found easy or difficult to fatten, precisely in that degree in which it may be well or badly made. A horse, for instance, having few defective points, will take on both flesh and fat more readily than one of a different and inferior structure. Of the common sheep I possess, one is conspicuous for beauty of form. She is always in better order than the rest, their chances being equal; and her lambs are for the most part the best I have. She last year nursed two lambs without any additional food, which are not inferior to any of the same age. Merino sheep, at least those that have come under my observation, possess every advantage in point of form. Compared with other sheep, they exhibit the same superiority that the thorough bred English bull does over the common scrubs of the comtry, and that they are really more easily kept, is no longer a matter of opinion. Lord Somerville, who has paicl particular attention to this matter, asserts "that the same land which carried indifferently 45 long woolled sheep, maintained, in good plight. 150 ryelands, the lambs of which were weaned in good order. These lambs were summered on the same land, at more than twelve per acre; and although kept hard during the winter, the wethers fatted to sixteen pounds the quarter." Laurence obsterves, "in genemal, land worth a guinea per acre, will carry and keep in good store state, $61 / 2$ Spanish ryelands, from 4 to $41 / 2$ Spanish Southdowns, allowing turnips, pease, and hanlin in the dead winter months. 
The largest breed of Sonthdowns, are stocked in Sussex, at the rate of four per acre; of full blood merinoes it will carry a proportionably greater number. They have been found very apt to take on both flesh and fat." "It is understood," says Colonel Humphreys in his letter already referred to, "that the merinoes are more easily maintained and fattened than the taller and larger breed, insomuch that there are persons acquainted with both breeds, who calculate that 200 of these small-boned and short-legged sheep may be kept in tolerably good condition, where 20 of the other would suffer for want." Tollet asserts "that one acre of land which will keep three Southdowns, (similar to our sheep) will be sufficient to keep four merinoes." He adds what is worthy of great attention, "the produce in wool of the Southdowns, would be $18 \mathrm{~s}$. $6 \mathrm{~d}$. per acre, that of the merinoes 3l. 15s. 6d. sterling." "The common sheep cast their wool in the spring of the year, the merinoes do not; this then is another advantage. The French, English and Swiss Agriculturists, have for particular purposes permitted the wool to remain on the sheep for two and even three years, without injury to the sheep or loss to the grower, for they then afford twice or three times the usual quantity of wool, and of double or treble the usual length. The same experiment has been tried by Mr. Rutherford, of New York, with a 7-8 ram, and with similar success. From this, another advantage arises, which is certainly of importance, in a climate so variable as ours; I mean the not being obliged to shear them at an unseasonable time. "Sheep are subject to colds and chills of the limbs," which always prove hurtful, oftentimes fatal. "The pelt rot," observes Mr. Livingston, "generally arises from hard keeping and much exposure to wet and cold, and in fact, the animal often dies in severe weather, from the cold it suffers by the loss of its coat;" and lastly they are less liable to disease. Poverty is the parent of half the diseases to which sheep are subject. If then merinoes have a greater disposition to fatten than common sheep, they are of course exactly in that proportion more free from those distemjers which have their origin in scanty foorl. 
Before I put an end to this communication, let me persuade every farmer, if his circumstances will admit of it, to procure, as soon as possible, a full-blood merino ram, if not, then one of the mixed breed, the higher the grade the better. By a single cross only, he will increase the value of his flock to an astonishing degree, and thus convert an evil into a benefit, since it has been proved that common sheep are not only unproductive, but really expensive.

I am sir, your obedient servant,

JoHN L. NoRTH.

J. T. Lewis, EsQ., Corresponding Secretary. 


\section{On Winter Fallowing.}

BY THOMAS PINCKNEY, ESQ.

Altamont, July 1, 1816.

Dear Sir-I beg leave to direct the attention of the Society, to an object I have long thought of the first inportance, and my observations during the last two years have so strongly convinced me of its great utility on our ridge farms, which are generally stiff clay lands, that I flatter myself the Socuty may think the subject worthy of their consideration: It is a winter fallow.

The modern improvements in husbandry have, I believe, entirely superseded the old laborions and expensive mode of cleaning lands by summer fallow. Fallow crops have been introduced which have the desired effect, and at the same time preserve the soils from losing their finer and more subtle particles by crioration, while they yield some return to the farmer for his labor. Still however, the principal object of a fallow crop is cleaning foul land, and if great judgment and care is not exercised in the selection and culture of the crop, the soil will be as much exhausted as by the old naked fallows. But the winter fallow has a higher object; its direct tendency is the actual improvement of the soil, by exposing it to the action of the winter rains and frosts, which perhaps more minntely enter, separate, and pulverize our stiff clays, than any other known agent. The action of frost, however, is generally limited to an inch or two below the surface, but by throwing onr stiff clay fields into five or six feet ridges, high on the crown, and the furrows made very deep, we admit this friendly agent to as great a depth as is necessary for most of onr crops. In this stage of the fallow, if manure of any kind can he procured, there is no mode of application more efonomical, or more immediately useful, than scattering it in the bottom of the deep furrows. In Narch the ridges are to be split down and gathered over the manure. Thus, every particle of the soil will be mover, and the frost, the manure, and the plough will have totally destroyed that compact adhesion which is th? 
unfortunate characteristic of our clay soils. Corn may then be planted from three to five or six feet distance on the ridges, according to the quantity of manure or quality of the land, with the greatest probability of a successful crop. From my own experience, I can affirm, that stiff clay worn soils have prodnced three times as much as they did, without the winter fallow and manure, and nearly twice as much, with winter fallow, and without manure, as they did without either.

I may be told, however, that manure alone, without the fallow, would be sufficient to produce this difference, and the labor of one plonghing be therefore saved; but a strong proof of the necessity of the fallow fell under my observation a week or two ago; so strong indeed as to have influenced my decision, to address this communication to you.

My neighbor had ridged up a field in March last, the ridges twelve feet apart, manure was spread in the furrows, and the ridges gathered orer the manure. I was convinced there was manure enough, as the roots of some stalks of corn, that had been thinned out, brought up large balls of manure, as they were pulled up. This field was planted the third and fourth days of April, and the corn appeared to be generally about three feet high, and looked indeed well, but not of that flourishing vigorous growth, I had expected from its culture and the great width of rows. A stiff field of mine, had been winter fallowed in the mode $I$ have mentioned, the last of November. 'The manure was hauled out and spread in the furrows, the middle of March, the ridges were reversed, and corn was planted four feet apart, the last day of March, three or four days only sooner than my neighbor's; and it did appear to his manager and myself, that my corn was twice as high, of a deeper color, and generally more vigorous and luxuriant; yet their treatment was similar, their culture equal; his land naturally better than mine, his rows twice the width, but his field laid hard and compact, nnder the frost and snow of the last winter, being only ridged in March, while mine was ridged in November last, and exposed during a hard winter to the full influence of the frost and snow. This case appears to me decisive of the great advantage of a winter fallow, 
A proof of the utility of this operation is, that for several months after forming the new ridge in the spring, the soil of it continues to be mellow and loose, affording fine pasturage for the roots of plants, and although a plough is never run across the ridges, so as to displace the manure or destroy the young roots; yet they are so open and mellow, that your walking stick may easily be pushed down to the bottom of the winter furrow. It is self-evident that this must be greatly advantageous, and consequently the plant arrives sooner at perfection, as its growth is never retarded by the struggles of the young roots to penetrate a stiff soil. I remarked last summer, that the fodder and corn were taken ten days or a fortnight sooner from the part of the field that had been winter-fallowed and manured than from other corn planted at the same time, and one acre of the fodder of the former was worth that of two acres which had not been so treated.

Among the numerous incidental advantages of this practice may be also stated, that of destroying most of the weeds by turning them up to be killed by the frost, and their decay assists to enrich the soil. I should think it strange indeed if our fields were not clean, when the weeds are so incessantly attacked by the frosts of the winter and the ploughing of the summer, in this mode of culture.

But again, I may be told that even gold may be bought too dear, and that this operation in husbandry, though beneficial, will not pay by its surplus product for the surplus labor it requires. As this is an objection which may at first appear reasonable, and which if well founded, would of course render the practice of winter fallowing ineligible, I will very briefly examine it.

I presume that I am correct in stating the value of the labor of a man with his horse and plough at one dollar a day. Let us suppose we have a field of stiff red clay of ten acres, and that by industry and judgment, it will produce in the common way, ten bushels to the acre. The only difference in the labor and expense of culture of the two modes, is the ridging up in the beginning of winter in the practice of winter fallowing. For the reversing of the ridges in spring, is not more expensive than the common mode of preparing a field properly for planting. I 
know that an acre a day is light work for one plough, the expense therefore of ridging up the field is ten dollars, and I really believe all other expense and trouble to be equal in both modes. The produce of the field in the common mode is one hundred bushels, and I can hardly prevail on myself to state the produce of the winter fallowed field so low as fifteen bushels; I feel well assured from one year's experience that it is double that of the common mode, but even at one-half more, its produce is one hundred and fifty bushels, which additional fifty bushels you get for ten dollars. To this is to be added, that your fodder in quality and quantity is superior in the same proportion, and if you have peas in the step on the ridge, their produce also excels that of the common mode; in a word, your crop is one-half better in all respects. It will be remembered too, that your winter fallowing can be done in a season of leisure, and that your soil is improved by pulverization and the destruction of weeds.

If these are facts, sir, which I have stated, and I have myself no doubt of their reality, they are worthy of consideration; and with a sincere hope that they may be beneficial to those of my brother farmers, who have stiff clay soils,

I remain very respectfully,

Your obedient humbie servant, Thomas Pinckney, JR.

J. T. Lewis, EsQ., Corresponding Secretary. 


\section{OX PEA HAY.}

BY THOMAS PINCKNEY, JR., ESQ.

Altamont, September 9, 1816.

Dear Sir-A committee of this Society was appointed during the last year, and charged to discover and recommend some mode of maintaining farm stock, besides the incessant application to the corn crib. This committee, among other substitutes and aid, recommended pea hay, as affording a rich food for horses and cattle, and whose culture at the same time, was easy, and its growth beneficial to the soil. Believing the recommendation to be judicious, I have adopted it, and now take the liberty of submitting to the Society the result of my first crop of pea hay.

The last of April I ploughed up an old field which had been in corn the preceding year, a stiffened clay, much worn, and of which about two acres had been manured for corn, the preceding year. Across this ploughing I drilled in peas with a shovel plough, three feet apart, on the 6th and rth of May. I ploughed them twice; the first time between the 1st and 3rd of June, the second time between the 20th and 24th of June; I hoed them once, the end of June. This is all the culture they received. On the 26th of August I began to cut the pea vines, and finished the . 27th, cutting half the field which consists of fourteen acres. In most places the dry weather had injured them, and they did not look as flourishing as I expected. Four days after cutting them, I turned them, putting two rows into one, and on the sixth day I turned them again. On the morning of the eighth day, I began to haul them in, and finished the next day ; and they have produced me twenty-five heavy wagon loads of rich, good fodder. As this produce may be best understood by comparison. I will state that I had a field of corn of twenty-two acres adjoining of new land, only the second erop, which had been planted very early, and had not suffered by the drought: the fodder was very good, and was carefully saved, and produced me sixteen wagon loads.

I am extremely sorry I have not the means of weighing a load 
of the pea fodder, but I should think a wagon load of it must weigh nearly twice as much as a load of corn blades, and the difference in quality is very great. Twenty-five loads from seven acres and a half in one case, and sixteen loads from twenty-two acres in the other. Less than two-thirds of a load of blades to the acre, and more than three loads of pea fodder to the acre.

If it be true, as has been stated to me, from the best authority, that a peck basket of these vines, chopped in a common cutting box, twice a day, is good sufficient food for a horse, with a small portion of blades, when not at hard work, I should not hesitate to believe this produce to be superior to that of a regular corn crop, on such land, which could not be expected to produce much more than ten bushels to the acre. Indeed I know positively, from my memorandum book, that its produce last year, under favorable circumstances, was but ten bushels and a half. At this rate my seven acres and a half would produce me but seventy-eight bushels of corn, and about five wagon loads of fodder. Let us suppose a heavy load of this fodter to be equal to seven bushels of corn (and I would not exchange it for ten), these seven acres and a half have produced me that which is equal to 175 bushels of corn, in feeding cattle and horses; and I know it would puzzle the best farmer to produce half this quantity fron these seven acres and a half, in their present state. If to these advantages we add that peas are an ameliorating crop, drawing very little from the earth, and shading and protecting it from the powerful influence of the sum, that their leaves are mostly left on the soil, to enrich it, and that they are a fine preparatory crop for wheat, as they may be got off the land exactly in time to prepare it for seeding. I think that we shall agree that the committee have been very judicious in recommending the pea culture; and I hope my success will induce some of my brother farmers, who have fields requiring rest or shift, to substitute a crop of peas for the common mode of sowing oats or wheat, which are exhausting crops. 
The Society will readily perceive the error I committed in this crop: The peas were sown, as I have stated, on the 6 th and ith days of May, when they ought to have been sown as early as the frost would permit. This circumstance and the late dry weather evidently injured them very much.

I am, dear sir, very respectfully, Your obedient humble servant, Thomas Pincknet, í.

J. T. Lemis, Esq., Corresponding Secretary. 


\section{First Piesident’s Valedictory.}

Pendleton, June 12, $181 \%$.

I offer you, my brother farmers, my best congratulations, on the return of this second anniversary of our Society, and I fervently hope that each succeeding year, may still find us in the path of public usefulness, and supported by the voice of public opinion. All reflecting men must applaud our motives, and I trust that the wisdom of our measures will equally merit their approbation.

It is a source of the most pure and heart-felt joy to me, that I am enabled to state to you, that we have always been useful. The first object to which the Society turned its attention, was the improvement of our wheat crops, and behold our ficlds are now loaded. I have been informed, that one-third more wheat will be reaped this year, than was ever raised in this district. This is an inspiring fact, and should stimulate us to proceed with increased ardor, in our laudable career.

The term for which I have been elected, having expired, permit me, before I retire from the chair, as my last official act, to implore your attention to an object, without which, there can be no good farming; an object that will double our comforts, and quadruple the value of our lands; that will enable us to raise four fat oxen, where we now barely sustain one; and in short will raise us to the rank of real farmers, rioting in abundance, instead of being mere laborers, struggling for subsistence. This important object is meadow. And never, in my humble opinion, shall we truly prosper, until we admit hay fields, as a regular rotation among our grain crops. Sow clover seed on your wheat before the frost is over, strew plaster of Paris on your young clover, and the experience of all farming countries will tell you, you have the secret of abundance, and improvement with the least labor. Give the clover a fair and impartial trial; and should this trial prove that our sun is too hot for its successful cultivation, we have native grasses that may supply its place, affording a finer, and I believe a better hay, though not so rich 
a pabulum for our soil. I forbear to trespass on your time at this monent, to detail all its various advantages, your own judgment and your books will convince you, that the introduction of clover and plaster, has formed a new era in agriculture, it has resuscitated whole districts. Would that my powers of persuasion were equal to my zeal on this subject, and that I had the talents to tempt or persuade you to depart from the beaten track, even for one small experiment. I deem this object so all important to us, that I will not risk dividing your attention by mentioning another subject. I hope and persuade myself that the views of the Society, will encourage individual attempts to introduce grass fields as a regular rotation, and the last words of your first President are, "gentlemen make hay." Thomas Pinckney, JR. 


\section{Address of John L. North.}

ON HIS ELECTION TO THE PRESIDENCY OF THE FARMERS' SOCIETY, JUNE, $181 \%$.

Gentlenen of the Societr-The very flattering mark of approbation and confidence that you have been pleased to bestow on me, leaves me no alternative; I have therefore to entreat you to exercise towards me, that indulgence which my predecessor has rendered so necessary, by his very able discharge of the duties of the chair; and to accept my warmest acknowledgments for the honor you have conferred. I will endeavor to repay the kindness, which, in elevating me to the first office in the gift of the Society, has overlooked so many errors and deficiencies, by a faithful performance of the obligation I have come under, and an early and zealous regard for the interests of the Society. Duly appreciating these promises, I cannot but persuade myself, that the following attempt at calling to your recollection, some of the purposes for which our institution was formed, and pointing out a few of the advantages of a close and constant attention to rural affairs, will not be out of place, at this time. It is a lamentable truth, that under the present mode of tillage, our lands are ruined in a few years, whilst the crops we draw from them, give a very inalequate return for our expenditures of labor and money. To cut down and fence in our lands, to grow on them, for a few ycars, annually decreasing crops, then to give them up to weeds and briars, and finally to abandon them in quest of new settlements, is the only rotation now in rogue amongst us. Nor do the evils of this system, great as they are, stop even here; they are usually only the forcrunners of the most abject porerty; for it will easily be seen that it is scarcely possible to escape this condition, if to the loss sustained from waste and forced sales, we will take the trouble to add the expense of frequent removals, and the pernicious habits they either introduce or confirm. It was once hoped that this state of things would work its own cure, by leading us to enquire into 
its causes; and eventually to seek relief from such measures as promised it, at the least expense, and with the greatest certainty. It therefore was eagerly expected that ameliorating crops would soon regularly succeed those of an opposite character, recommended as these so strongly are, by successful experiment, both in Europe and this country. The system of manuring, without which there can be no profitable farming, and which can be obnoxious only to laziness or inveterate prejudice, it was supposed would immediately become a general favorite. The plan of pasturing fields, already injured by a series of exhausting crops, it was thought would speedily be abandoned, and the desolating course of tobacco, corn, cotton, wheat, rye and oats, shunned as the plague. Reasonable as were these hopes and expectations, I am mortified to say they have not been realized; and to ald that our advancement towards such a change has been but partial and limited. To place its advantages in the clearest point of view, by comparing them with the folly and destructiveness of the mode of husbandry now practised by us, and thus to recommend this change for general adoption; to set an example in the work of reformation; to stimulate exertion by rewarding merit, and by encouraging enquiry, and diffusing information, to leave ignorance and idleness and prejudice without excuse, are amongst the most prominent objects of our association. But it is not to the introduction of a better mode of tillage only, that the views of the Society are confined. The improvement of stock of every kind, constitutes another object of its anxious pursuit; and without taking into consideration the intimate connection between attention to stock, and improvement in husbandry, may I not venture to assert, that there is not a person of the least taste or feeling, who has not often regretted the mean and degenerating condition, and felt for the sufferings of our cattle, exposed as they invariably are, with nothing but straw for their food, to all the severity of the winter. And can it be reasonable to expect that with such treatment, in winter, withont shelter, and with a pittance so tasteless and unsubstantial, and in summer with no other pasture than what our woodlands afford, that cattle will improve? Do you increase the power or usefulness of a mill, by lessening the requisite head of water? Are rivers made navigable by having their supplies cut off? Be assured that it is only to unremitter attention to 
their necessities, and even ease, we are to look with confidence for any material alteration in their size, appearance and usefulness. And when we turn our eyes to the state of our sheep, do we not see almost as much to censure? From observation and experiment, I have reason to think that this state is, in many respects, as friendly to the constitution and habits of this useful animal, as any of the Northern States; yet their sheep surpass ours, as well in size and beauty, as in weight and perhaps fineness of fleece. To what then are we to attribute this difference? Are our oak ridges so small and barren, that sheep cannot thrive on them, or is it because our winters are so long and pinching, and our summers are so wet and hot? Or perhaps it is for want of water and shade, that they do not prosper with us. In many of these particulars we have a decided superiority. Our ridges are large, and though unfit for the purposes of the plough, yet produce an herbage peculiarly grateful to sheep. Our summers are dry; I believe less sultry and oppressive; and our winters are certainly less humid, more moderate, and of shorter duration: never failing springs and branches abound, and our country exhibits every variety of surface. To speak out then, it can be ascribed to nothing but our habitual, I had almost said, proverbial carelessness and inactivity, throughout the winter months especially, on the one hand; and on the other, to the diligence and care with which the farmers of the northward provide during the whole year, for the wants, and even comfort of this helpless, but valuable animal. I might enlarge on many other particulars to which the design of our institution extends; but on this subject I have already trespassed too long on your patience; I will therefore but briefly add, that it embraces every thing connected with rural affairs; the introduction of live fences; manures of animal, mineral, and vegetable origin; their nature and suitableness to our lands; the nature of our soils; draining and irrigation; the improvement of fruit trees; the dairy, and even the stye.

I come now to say something of the benefits of a close and continued attention to rural affairs; and these are so numerous and important. that I hardly know where to begin, or how to particularize. Perhaps I cannot fall on a better method to attain my ohject, and at the same time insure perspicuity, than 
that of contrasting the result of our manner of conducting a farm, with that of those who have taken the lead of us, in every convenient, elegant, and profitable improvement in husbandry. That we grow not more than seven or eight bushels of wheat on an average, whilst others raise as much again to the acre, I mention at once, as a reproach and incentive: will it be credited, that persons who are well assured that twenty, thirty, forty bushels and upwards, of this grain, have been produced on that quantity of land, will yet remain satisfied with seren or eight? In the Jew's letter's to Toltaire, it is asserted that upwards of one hundred bushels of wheat have been obtained from the acre; and that this matter of great novelty, may be inferred from their founding, on that very circumstance, the charge of more than ignorance or negligence in Voltaire's silence on the subject. Nay, when in this district there have not been wanting, some two or three instances, where the average to the acre has exceeded thirty bushels; and yet unaccountable as it may seem, we still persist in farming it according to the old, laborious, pestilential and ruinous mode. In other respects the difference against us is equally great, whilst we grow but about one hundred or one hundred and fifty bushels of sweet potatoes to the acre, five times that quantity are made in the low country, from the same ground. I have heard of a Mr. Ford there, who has even raised one thousand bushels to the acre, and that with no other manure than the nffal of the barnyard; nor do our Irish potatoes generally stand better footing. I notice however, with jleasure that in a solitary instance,in this neigh jorhood, in proportion to the land planted, upwards of one thcusand bushels would have been taken from the acre. Is it necessary to inquire if these facts establish the advantage of good farming; or if these actrantages be within our reach? With Indian corn too, the balance is evidently against us; although orir suil and climate are admirably adaptird to its culture, we seliom exceed forty bushels to the acre, on our best low grounds, and twenty on our high lands ; whilst in New Jersey, an acre has yielded one hundred and eighteen bushels, two quarts; and the average crop, after ordinary manuring, at the northward, I believe to be seldom less than fifty or sixty bushels to the acre. In one instance, in this district. I have known good tillage and manure to have occasioned in the same field, a difference of nearly three to one, in their 
favor. But I will detain you no longer on this point, than to beg of you to use the means within your power, vigorously and judiciously, and thus speedily to remove the reproach from us.

I have already remarked that the cattle of this country are poor, ugly and degenerating, and that nothing short of a total alteration of our treatment of them, will remedy the evil. To prove that it will do so, I beg your serious attention to the following statements, in which I have been so particular, because I hope that some of you may, by that means, be encouraged to imitate such worthy examples. "Col. Abel Chapman," says a writer in a respectable Boston paper, "has raised some celebrated cattle, which were weighed on foot last Thursday week. The weight of the largest ox was 2,716 pounds the smallest weighed 2,240 pounds. The former exceeded by 12 pounds the weight of the celebrated Durham ox killed in England, in 180\%, and for which 2,000£, sterling had been refused." "The finest breed of bulls and other cattle ever reared in England," says Mr. Willich, in his Encyclopedia, "was that of the late Mr. Fowler, of Rollnight, Oxfordshire,whose stock was sold by auction, in 1791." Mr. Willich, "was among those who witnessed this enchanting exhibition of animals, and admired their incomparable size, form and vivacity. Fifteen prime heads of cattle, namely, five bulls and ten cows, were scparately sold for the enormous sum of $2,464 £$ or, on an average, $16+£$ each; the finest bull, named Sultan only two years old, was purchased by Messrs. Freeman \& Eden, of Gloucestershire, at the price of 2201. 10s." It is stated in Mr. Niles' Weekly Register, page 136, No. 9, vol. xii. that "one hundred and eighty head of cattle, (one third of them yearlings and calves) bred by a Mr. Price, near Upton, sold for the enormous sum of $7,600 \mathfrak{E}^{\prime \prime}$ - one yearling bull for $341 £$ 5s.-a heiffer for 252l." - - and in No. 18, of the same vol. that "an ox bred at Springfield, Massachusetts, weighed on the hoof, 3,100 pounds his length from the top of the nose, to the root of the tail, was ten feet seven inches; circumference eight feet nine inches." To obviate an objection that may here be made on the score of climate, \&c I introduce from Judge Johnson's Essay, delivered to the Charleston Literary and Philosophical Society, a fact that will go very far towards removing it. "Mr. Christopher Fitzsimons purchased a cow of the common breed that range over our pine lands; yet this cow, by being liberally fed, 
was brought to give as much milk as twelve of those which ordinarily disgrace our cowpens, and her calf when killed for veal, weighed as much as an ordinary two year old, and full as much as a calf of the large imported breed at the same age." Nor ought I to pass over, in silence, the amelioration that has taken place in the condition of sheep, principally amongst food farmers at the northward. Mr. Livingston, in his book on sheep, gives it as his opinion, that his famous ram Clermont, which at two years old weighed 149 pounds would when full mouthed, and in good order, go up to 190 pounds. In the essay above referred to, Judge Johnson mentions that "Mrs. Melvil, of Savannah, raised two pet lambs, which he had it in his power to ascertain were of the most common breed of the country; yet the fleece of one of those sheep weighed 14 pounds the other 15 ponnds, the wool was very fine, and the staple was of the average length of fifteen inches, some of it went up to eighteen inches." And I remember to have seen it incidently mentioned in the account of a cattle show, near Philadelphia, in the year 1813, I think, that a wether weighing considerably more than 200 pounds had been killed, in the market in that city, the year before. When to these facts we add others which you no doubt recollect, and compare them with such information as we possess, with regard to our own sheep and cattle, what further proofs ean we require of the benefits that follow care, perseverance and judgment: or of the evils that attend negligence and shoth. That fruits mav be increased to any desirable extent there can be no loubt, since it has been ascertained that even the fig and black heart cherry, will answer very well here: and that they may probably be greatly improved, I again avail myself of Judge Johmonn's easay : in page 22, he says, "indeed it is scarcely credible to what perfection the peach and the grape have becn brought in this State. One hardly dares assert, that the former has attained the size of a foot in circumference, and the bunch of the latter 3 pounds in veicht." In another place he says, "I have seen five different kinds of the most luscious grapes of Europe. heaped on a table in the month of October; and this was in the most obscure parts of the State." One more fact and I have done. But a few vears ago, the lands of Loudon county, Virginia, exhausted by the desolating rotation of whent and tobacco, were purchased by a set of industrious and intelligent 
Pennsylvania farmers, at about five or six dollars per acre. The same lands, improved as they are, by manures and judicious farming, will now bring from forty to fifty dollars per acre.

Before I close these few statements and remarks, I feel it my duty to beseech you to attend more diligently to such experiments as you may undertake, with a view to the advancement of the plans of our institution; and to conquer that bashfulness, which keeps you from communicating the results, whether prosperous or adverse, with such obseryations as you may make on the causes of failure or success. The zeal of a few individuals may remove some of the smaller objections from the stream of agricultural knowledge; but it is only by the united and spirited exertions of all, or most of the members of this society, that it can be cleared out and deepened, as to be made extensively and permanently useful. Books may, and will assist us; but they will not supersede the necessity of candid personal observation and experiment. It is only on these often repeated, carefully noted, and honestly communicated, that we can build our improvements. We may learn a great deal of a country from the writings of others, 'tis only by travelling over it frequently ourselves, that we can become intimately acquainted with it. I have now nothing to add, but to express a hope, that we will remain no longer insensible to our favored lot, or regardless of our own comfort, or the welfare of those that may come after uls. 


\section{Report of the Comartetee on Manulies.}

PRESENTEd July 9, 1818.

The committee on manures, in obedience to the direction of the Socicty, at their last meeting, beg leave respectfully to submit the following

\section{REPORT :}

Aware of the great importance of the subject, and of the difficulty of arranging a system, at once simple and efficient, your committee have felt themselves embarrassed by another consideration of a painful nature. A conviction that an incompetent discharge of their duty may lead their fellow citizens into errors and losses, and endanger the reputation of a system on which all good farming is founded, and which, when judiciously prosecuted, has always been attended with the most beneficial effects. Your committee however, have not suffered themselves to be deterred, even by this consideration, from uniting their most zealous efforts in so good a cause; and trusting to superior wisdom for a happy issue, they will only add, that the subsequent recommendations are founded either on their own knowledge and experience, or derived from the best and latest authoritics, to which they have had access.

Before entering upon the subject of their immediate duty, your committee would earnestly recommend to their brother farmers to examine and ascertain precisely, the nature of the soil which is to be the subject of improvement. In the vegetable, as in the physical world, the nature of the defect should be completely understood, in order to adopt the appropriate remedy; and as our fields not only differ materially, but are even sometimes of an opposite quality, it is evident that a very judicious course of management for one field, may be extremely pernicious for another. 
Believing this point to be of primary importance, your committee will endeavor to assist the judgment, by enumerating the different soils of this district, as far as they are acquainted with them; and for this purpose it will be sufficient at present to consider them under three divisions :

First: Stiff clay soils, generally red, with more or less sandy vegetable earth on the surface.

This soil is mostly sterile, after a few years of cultivation in the ordinary way; but as one principal cause of its sterility is its adhesion, and as clay is known to contain a great portion of the food of plants, it follows that the first step towards improvement, is to destroy its adhesive quality, in order to enable its fertile particles to act. To accomplish this object, clay soils should be mixed with such particles as tend to open them and break the cohesion of their parts; when this is accomplished, this land becomes highly valuable, retaining manures for a length of time, and with good management will never return to its former state. Among other substances proper to be mixed with this soil, may be enumerated sand or gravel, ashes, saw-dust from mills, rubbish from old buildings or yards, straw, stubble, rotten wood, burnt clay, farm-yard manure, and gypsum, or plaster of Paris. 'Tanner's bank, and substances which promote a strong fermentation, are peculiarly excellent, and it is believed that a mixture of any or of all of the above mentioned substances, in a composed heap, would triple the product of such land, if properly ploughed in and brought into good tilth by the plough and harrow.

The second division may be called a loamy soil. This kind of earth is less cohesive and more fertile than the former, and is composed of sand,clay, and an oily vegetable substance, with a substratum of red clay at some depth, on uplands, and generally of bluish clay on river or creek bottoms. These latter are generally admitted to be so fertile as to require little aid from manures; but the uplands after a few years cultivation will require a compost of stable manure, sand and regetable rubbish, to break the tenacity, and recruit the poverty which successive crops will produce. Loads of mud and decaying leaves, hauled from creeks and stagnant pools, are very highly recommended for this soil, and the proportion of sand or gravel should be increased as the land becomes more stiff. 
The third division will comprise light sandy soils, with an ash colored mould at top. This soil is more porous and open than those which we have considered. It receives moisture with great facility, but parts with it as easily. To improve this soil, clayey loamy earth must be spread over it, and composts of animal and vegetable substances; but all light sandy particles must be carefully avoided. This kind of earth is the only one in this district, which will bear what "Arator" calls, "the American custom of penning," as the treading of animals impart a firmness to the soils which in a gieat measure will prevent the continual cooperation of moisture, while it receives great benefit from their manure.

Your committee having thus briefly endeavored, (by this classification of the great bulk of the farms of this district), to erect some standard by which an intelligent farmer may correctly ascertain the nature of his soil, its defects, and their appropriate remedy, will proceed to the subject immediately committed to them; the collection and application of manures.

All the manures which can be used in this district, may be classed under four heads: animal, vegetable, compound, and fossil.

Animal manure, by which we at present mean, the dung of horses, cattle, sheep, and hogs, with the refuse of the poultry yard, is one of the most powerful manures that can be applied to the soil, and the most approved modern writers strongly recommend that it be immediately buried beneath the surface, there to undergo its putrefactive process, that the earth above may be benefited by the ammonical gas which it evolves in its decomposition. The dung of horses, hogs, and poultry, on account of its great tendency to fermentation and putrefaction, is best adapted to cold, stiff, and clayey soils; while that of cattle may most beneficially be applied to warmer soils. On sandy porous soil, cattle may be confined by a temporary fence, on a strip of land, which being removed at a given time, (according to the number confined thereon), their dung should be immediately plonghed under, that it may not be exposed to the action of the sun, or of rain. Put as nine-tenths of the farms of this country, would be materially injured by the poaching of the soil; and as very few of our farmers keep a sufficient stock to improve any quantity of land, in any way, by animal manure alone, your committee will 
not detain you longer on this head but will proceed to the consideration of the second class, or vegetable manure.

In this division, we comprehend either green plants turned under by the plough while growing, or parts of vegetables, after they have been decomposed or burnt, with their ashes, roots and fibres.

The only experience your committee themselves have had of ploughing under any vegetable substance standing on the soil, is the case of ploughing in stubble. This practice has for a number of year's been performed on cold, stiff, blue clay river bottom land, from which a succession of the same crops, for perhaps seventy years, had worn away all the top or regetable earth. 'The practice has always been attended with beneficial results; for though the stubble is a long time in decomposing, and affords but little soluble matter for the food of plants, yet the tenacity of the soil is always broken and a considerable degree of tilth produced, enabling the fibrous roots of the plants to penetrate in all directions in search of their food.

But if dry stubble plonghed under, produces such happy results, how much greater would be the benefit if a green crop, in full luxuriance, in the season of its blossoms, were treated in a similar manner. The interior woody fibre of the vegetable, taking a longer time to decompose, would have the same effect as the stubble, of opening the soil, while the juicy bark and leaves, speedily undergoing the putrefactive process in the earth, would impart a richness and fertility to the soil, which would amply repay the little labor and expense that would be incurred. Lord Kaimes objects to ploughing under green vegetable crop, merely because the vegetables commonly used for this purpose, are proper food for animals, and he conceives that the best way of ccnverting it into manure, is to pass it through the body of an animal, which will increase its value, while the dung and urine will enrich his soil more than ploughing under the green crep. Your committee will indulge thenselves in two remarks on this objection. The first is, that so little labor and expense is required in seeding and the two ploughings reguired by the vegetable system, that any common industrious farmer may sow one field for feeding and others for turning under, and if the green vegetables are to be cut, and carried perhaps some distance, to the stalls and sheds, to prevent poaching, this continued daily labor, will 
make it the most expensive mode. The other, and stronger objection to Lord Kaimes' plan, is that few, if any of our farmers keep a stock sufficiently large to manure any quantity of land, by the dung of animals alone, while the vegetable system manures the whole field at once, and equally.

Sir Humphry Davy, in his lectures on agricultural chemistry, observes, that "all green succulent plants contain saccharine or mucilaginous matter, with woody fibres, and readily ferment. When they are to be employed for enriching a soil, they should be plonghed in when in blossom, for it is at this period that they contain the largest quantity of easily soluble matter, and that their leaves are most active in forming nutritive matter. Green crops, pond weeds, or any kind of fresh vegetable matter, require no preparation to fit them for manmre. The decomposition slowly proceeds beneath the soil: the soluble matters are gradually dissolved, and the slight fermentation that goes on, checked by the want of a free communication of air, tends to render the woody fibre soluble, without occasioning the rapid dissipation of elastic matter." In speaking of dry straw, the same anthor states, that when it is made to ferment it becomes a more manageable manure, and that it is usual to carry it to the dung hill for this purpose; but he says, "it is worth experiment, whether it may not be more economically applied, when chopped small by a proper machine, and kept dry till it is ploughed in for the use of a crop. In this case, though it would decompose much more slowly, and produce less effect at first, yet its influence would be much more lasting."

On this latter point, of dry straw, it is sufficient to remark, that this celebrated chemist does not positively recommend that it be ploughed in without undergoing fermentation; he states it as a subject of doubt, and worth experiment, and only believes it to be more economical. He has himself given us the result of an experiment of his own, which should teach us that the only use of applying dry chopped straw, would be the opening a stiff soil. In the very same page from which the above recommendation is extracted, he says, that "from 400 grs. of dry barley straw, I obtained 8 grs. of matter soluble in water, which had a brown color, and tasted lite mucilage." From 400 grs. of wheat straw, he obtained only 5 grs. of a similar substance. This experiment sufficiently demonstrates, that there can be no comparison be- 
tween mere woody dry fibre, and the suceulent luxuriance of a vegetable in full sap; but should any further elucidation be wanted. we have in the very next page of the same author, a fact which ought to satisfy the most sceptical. It is in these words: "Woody fibre will not ferment, unless some substances are mixed with it, which act the same part as the mucilage, sugar, and extractive or albuminous matters, with which it is usually associated in herbs and succulent vegetables."

For precision and accuracy in chemical experiments, Sir Humphry Davy may be safely trusted; but your committee can not believe he was a good farmer. Indeed most of his experiments, instead of being applied to the valuable productions of the field, were made on "mint" and "primroses," in his garden.

Your committee have read with much pleasure, two small agricultural tracts, published by Mr. Matthew Peters, and recommend them to the attention of the Society, particularly those parts which relate to the subject now under consideration. These works, "The Rational Farmer," and "Winter Riches," contain many valuable hints on all subjects connected with husbandry; but he appears to be most intelligent and zealous on the subject of the vegetable manures, at equal war with both hot and short muck farmers. He goes on so far as to say that all animal and compound manures should be excluded from tillage land, and should he applied to meadow and pasture alone. Two of his reasons are so strong, as to carry conviction of their truth, while others are so plausible, as to invite the experiments of all farmers. The former may be stated briefly to be, first, the comparative facility with which a whole field may be manured at once: and secondly, the exemption from weeds, slugs, trash, and rermin, which farm-yard manure never fails to reproduce. Your committee, in the absence of their own personal expericnce on this subject, will briefly state his mode of bringing a field into good tilth and fertility, and it is worthy of remark, that his soil resembles that of far the greater part of our farms.

About the first of October, he breaks up a stiff field and sows, pretty thick. turnips and barley, or rye and oats, (in all cases of turnip sowing, he mires one quart of radish seed with four quarts of turnip). This crop is sown on land, ridged for winter fallow. In Februarv you may put in ewes and lambs. In April or May this vegetable crop is turned completely under, with a 
proper plough, and on the furrow he sows buckwheat, turnips, and retches, any or all (but a mixture seems preferable), and harrows them lightly. Thus you have one crop of vegetable manure under fallow, while another is growing above it. The end of July, or begimning of August, he turns under this second crop as before, and the end of September his field is ready for wheat.

This is perhaps too brief an analysis of his mode, a continnance of which he strongly recommends, and in conclusion he calls on all farmers, with the consciousness of agricultural integrity, to throw aside the wornout thread-bare garment of ignorance and perverseness, and to consider the advantages arising from two vegetable manurings, and a sprinkling of sheep manure, performing their putrefactive office within the soil, and keeping therein all their native salts and fertile oily juice, with only three ploughings.

Your committee though inexperienced on this subject, can not avoid recommending to this Society, the adoption of a plan on principles similar to those of Mr. Peters. The end of September, any of the following seeds, or a mixture of them, as judgment may dictate, should be sown, on one ploughing and harrowing in: turnips, barley, Egyptian oats, rye, Hanover turnip, or any other succulent regetable, not usually injured by frost. In the weaning season your ewes and lambs, and young calves may be pastured on it without injury. The end of April or beginining of May, this vegetable crop should be neatly turned, three to five inches deep, with a good bar share and two horses, having previously rolled it. Immmediately on this furrow, any or a mixture of any of the following seeds should be sown, and harrowed in, so as not to bring up the under part of the furrow just turned. Buckwheat, retches, or tares, turnips, cabbagc-seed, peas, chickory, and in general, all luxuriant, juicy vegetables. The first of August this second crop should be rolled, and neatly turned under; and if wheat, barley, or Egyptian oats are to be the crop for the ensuing year, they may be sown any time in September, or first half of October, taking great care so to water furrow your field, as to cause as little washing as possible. Should this field be wanted for corn, the next spring, it is recommended to sow it with turnip and radish in September, and your cattle, hogs, and sheep may be fed with the turnips in winter, and the field be broken up for corn the end of March. 
All clover and other grass lays have long been used with unvarying success, as a regetable manure. Their direct effect is to open and divide the soil by their woody fibre and roots, and to enrich it with their mucilaginous substances, which are easily soluble in water. Old pasture fields should be suffered to grow up for some time previous to being turned in, that a larger portion of vegetable matter may be imparted to the soil. It is not uncommon to see some worn out fields, thrown out of cultivation on account of their sterility, growing up in rag weed; the farmer of good judgment, keeping stock of every kind out, would turn under these weeds, before the seed begins to form. This process would encourage a more vigorous growth on the land, which should be treated in the same manner, and if he would but assist the benevolent designs of nature, and sow down a winter vegetable crop, the poorest soils would be restored to a state of fertility. Let the farmer who is afraid of a little trouble, compare the labor and expense of a few ploughings, with all the heavy and lahorious operations necessary in clearing new lands, and placing it in good order to receive seed; and he will find it less laborions to improve twenty acres of his worn out home fields, than to clear two. This calculation is within the reach of any one.

The ashes of all vegetables is an exceedingly useful manure, particularly to low wet and stiff soils. The vegetable alkali contained in them, gives solubility to all vegetable substances, and from its strong attraction for water, may tend to give some degree of moisture to the soil, or to other manures; on this latter account it is of great service, properly mixed in a compost heap.

There are many other vegetable substances which may, with success, be used in restoring worn out tillage land, but as most, if not all of them, may with far greater effects be transferred to the compost heap, your committee will proceed to the consideration of the third division, or compound manures.

Sir Humphry Davy informs us that all vegetable and animal substances are consumed in vegetation, but they can only nourish a plant by affording matter soluble in water, or gaseous substances capable of being absorbed by the plants. This great principle appears to be confirmed by several of his experiments, and is probably as correct an account of the food of plants, as 
we are likely to obtain. We know that all dead animal or vegetable matter, if sufficiently divided, spontaneously undergoes a process, which brings it at length to be a fat greasy earth, which we eall rich loam, or garden mould. The woody fibre of vegetables is longer in undergoing this process, but its texture is at last broken down, and it is resolved into new elements. Animals' matters, therefore, and the mucilaginous parts of vegetables being more liable to decompose than dry woody fibre, their mixture is evidently required by their nature, and hence the origin and necessity of compost heaps.

With regard to the fermentation of compost heaps, by attending to the foregoing principle, we learn that whenever they are composed of substances easily soluble in water, or easily disengaging their gases or vapors, their fermentation or putrefaction should be prevented as much as possible; and on the contrary, when they consist of woody fibre, and insoluble substances, such matters should be added to them as tend to promote fermentation. By attending to this simple principle, the farmer will be at no loss to prepare and manage his manure so as to make it most extensively useful.

Your committee having often had occasion thenselves, to complain of the want of detailed, precise, and specific directions, in justly celebrated authors, will endeavor to avoid this reproach while they proceed to recommend the best method within their knowledge of forming this most essential requisite on every farm-a compost heap. The principles have been already stated; the practice is founded on them, and a small share of industry and judgment is alone requisite to give it the most beneficial results.

A Bountiful Providence has placed everywhere, substances which form a manure for the soil; but man must not expect to sit still and that manna will drop into his mouth. His faculties and reason were given him for exertion, and materials are placed within his reach, to enable him by their exercise, to improve his condition. In the first place then, let every farmer mark out a small spot, from twenty to forty feet square, according to the size of his farm; this spot should be dng down from two or four feet deep and the earth should form a bank round it; a few stout post oak crotches should be planted in a line along the middle of this pit, and shorter ones should be placed 
at the sides, to receive strong poles, on which to erect a shed of common clapboards. Having thus cheaply made a shelter for your manure, which at once secures it from the sum, from rain, and from water running into it, while by removing a few of the boards, you can admit them when necessary; the next step is to bring to it a quantity of top earth or sods, and if your soil be stiff, a quantity of sand. These substances should be mixed, and a layer of one foot in thickness should be spread over the bottom of the pit; then cut down and collect all the weeds (before they seed) about your fence and farm, and spread another layer of them, of the same thickness, over the former one; then collect dead leares, by scraping the surface of the adjacent woods, and spread another layer of them; sprinkle this last layer with all the ashes and soot you can collect about the farm; next go into your stable and cattle yard; collect all the animal manure they contain, and lay on another layer of this dung; over this spread a layer of bad fodder, waste straw, sweepings of your yard, particularly after rain, and any kind of rubbish about your buildings. You will find that your compost heap will now be raised about five feet; but as this will probably settle, as decomposition takes place, to about three feet, you must begin again with your layers, and proceed till your pit is filled up. Should your soil be very stiff, it will be advisal)le to sprinkle two or three inches of sand or gravel between each of the layers, as one great recommendation of this plan is, that you may suit your manure to the nature of your soil. Should it on the contrary be light sandy and porous, a layer of loamy clay should be occasionally introduced.

This mode of making compost manure, requires but one part out of five of stable manure, to create a fermentation through the whole mass. Should it not speedily commence, you have only to remove some of the boards during the first rain, and the moisture and the heat will soon produce the desired effect. All the materials for the compost heap, should be placed ready round your pit before you commence, as perhaps it may be advisable to mix the substances a little together, and not let them lay in such detached layers. Should the heap become very hot, the quality of your compost will be injured, unless you open the mass in dry weather. A very valuable addition to a compost heap, is pond or creek mud, where it can be obtained, together 
with the deposits of leaves and other trash, found in lagoons; and your comnittee will enumerate some of the materials, most of which are within the reach of us all, which they recommend to be collected and prepared for composts.

It is presumed as a matter of course, that every one who calls himself a farmer, carefully saves all the dung from his stock of all kinds; to increase this, your horses' stalls, and the sheds or yards of your cattle and sheep, should be kept constantly littered with either corn stalks, refuse straw or folder, dried leaves or shavings. This will both increase and preserve your stable manure. The materials for the compost heap, may be sand or gravel; sods of top earth from lanes and hollows; green weeds of all kinds; (and rag or hog weed is excellent) dried weeds and leaves; ashes and soot; sweepings of yards, and all kinds of rubbish, saw dust from mills; creek mud and pond trash; rotton wood and bark; tanner's bark and offal; house and kitchen offal of all kinds.

Let not the farmer be misled by the opinion that these necessary operations will consume too much of his time; let him seriously set himself to work in hauling materials to his manure pit, and he will himself be surprised to find how easily and how soon compost is made when he has a little stable manure before hand.

It is believed that one man and one boy with a horse and cart will in less than one week create a mass of compost sufficient for five acres of land, and how many idle weeks do we all spend. It will be recollected also, that the greater part of this work can be performed at leisure times; the most proper and convenient for us; appears to be immediately after laying by our drill crops, as the vegetables will then be in full luxuriance, and we have some weeks of leisure. In forming your compost, the manure from your sheep yard and poultry houses must not be forgotten, and as these are of a hot and fermenting nature, they should be spread over those layers least likely to decompose without their aid. From six to ten or twelve weeks is sufficient with proper management to render the compost heap to a condition fit for application, and on emptying your manure piles, care should be taken to turn and mix the heap as much as possible.

Your committee could add many others to these recommenda- 


\section{Pendleton Farmers' Society.}

tions; but they forbear, relying both on the good sense and judgment of the Society to supply their deficiencies; and fearful of exhausting a patience so largely claimed and so liberally bestowed. In conclusion, they will only permit themselves to express a fervent hope that their labor may be useful, which will be their best reward, and that their brother farmers will shew forth their faith by their good works.

The remaining subject of consideration, that of fossil manures, together with the time and mode of application of all manures to the soil, must be the subject of a subsequent report, which your committee hope to have the honor of presenting.

All which is respectfully submitted.

Thomas Pinckney, Jr., Chairman of the Committee on Manures. 


\section{On Peas, Pea Vines, and Fattening Hogs.}

BY JOSIAH D. GATLLARD.

Pendeleton, August 13, $181 \%$.

There are perhaps, few parts of the United States, where a strict observance of economy in husbandry is more londly called for, than in this district; and I verily believe we practice as little as any civilized people in the world.

Our range, which some years ago, was as good as could be wished for, is now almost completely exhausted. It is at least so far spent, that during the spring and summer months, all that our eattle can glean from morning to night, is barely sufficient to make the most thrifty of them tolerable beef by fall; and that not without the assistance of bushes and weeds of various kinds; and the most of the different kinds of oak, which formerly seldom failed to be abundant, is now seldom sufficient for the support of our hogs, half of the winter; and although this want of range is so sensibly felt, we are (strange to tell) still depending altogether on crops of corn and small grain, badly managed on exhansted lands, to supply everything about us with food.

It lias been recommended in two excellent communications read before our Society, (as a cheap and easy mode of obtaining winter food for cattle, sheep, and horses) to cultivate the field pea, and I did hope that practice would have been generally adopted; but it appears that some further inducement is still wanting; it is therefore, I am induced to add my experience in the use of that valuable article.

In the fall of 1813, I purchased three acres of peas, as they stood in a neighbor's fichl. After two severe white frosts had fallen on them, I picked off all the ripe peas and such green ones as were full ; the vines were then pulled up, and after laying two days, were caught in a rain, which lasted the whole day. As soon as the smn har dried the npper side, they were turned, and three days after they were hauled up: the produce was one good wagon load and a half; they fed two cows and 
calves six weeks, once a day, and were eaten heartily, and much preferred to corn husks or wheat straw, and while they were fed on them their milk was much increased. The peas fed two horses, twice a day, for four weeks, during which time they got in fine order. These peas had been planted some time in June, among corn in the step, and I think ploughed and hoed once.

On the 6th of June, 1814, I planted peas in an eight acre field of corn, immediately after the second ploughing; they were put in the step with a hoe, and about twelve grains put in a hole; they were worked once with the plough and hoe; about the middle of September the vines were pulled up, and after laying four days turned; the seventh day all the dry peas were picked off, and on the Sth, the vines were housed. Two horses were fed on them twice a day, (and once in the day with sheaf oats), for five weeks, in which time they got in excellent order, and the balance fed two cows and yearlings, and four sheep, for three months. The two cows during this time, furnished generally about sixteen quarts of milk per day, and in the spring, when they were turned in the woods, one cow and yearling were good beef, and the others in good order. The corn among which these vines grew, made something short of ten bushels to the acre.

On the 16th and $1 \%$ th of the same month, I planted peas after the same manner, in seven acres of corn; these were ploughed and hoed once, early in Norember: all the ripe peas were picked from six acres of the best, the worst acre and all the green ones were left. Thirteen hogs, four head of cattle, two horses and four sheep were turned in the field, and they did not eat all the peas in seven days. After feeding two horses on the peas that were housed from these six acres, for two months, ten bushels were threshed out for seed and other use; the whole bulk after they were housed, was estimated at thirty bushels. The corn among which they grew, was supposed to produce twenty bushels per acre.

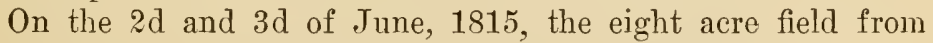
which I cured vines in 1814, and four acres adjoining, of the same quality, was planted in peas, after the same manner, and got the same attendance. Between the 20th and 25th of Sept. the dried peas were picked off, and the vines pulled up; on the fourth day they were thrown up in heaps about five feet high; on the serenth day were opened, and on the 8 th hauled in. These 
vines fed two horses, twice a day. for two months, and the balance fed four head of cattle and four of sheep, four months, once a day.

On the 12th, 13th, and 14th of June, 1815, I planted peas among eight acres of corn, after the second ploughing, (these were planted in double rows, that is, two of peas for one of corn;) they were ploughed and hoed once, early in October; they were seen by a great pea planter from the low country, and pronounced to be very fine; early in November, they were picked over once, and the bulk judged by the same gentleman to contain at least forty bushels of shelled peas; twenty bushels were threshed out for seed and other use, and the balance fed two horses better than two months. The corn among which these grew made sixteen bushels to the acre.

From the 20th to the 23rd of May. 1816, I planted peas in ten acres of corn; these were dropt in the furrow next the corn on both sides, and covered with the plough; they received one hoeing and ploughing. From being planted so near the corn and in such quantity, each injured the other, and the drought in addition, rendered the peas on the poorer parts of the field unpromising. The vines from these parts were pulled up and fed to my horses and cattle in September, for the want of pasture for them; the other five acres being stronger land and lying lower, were suffered to ripen; and although they were injured by deer, which frequented the field every night, for some weeks, and they were not picked until late in October, they produced twenty-five bushels of shelled peas: and from two acres of stiff old bottom planted on the 19th of .Tme, after my old method, and ploughed and hoed once, I gathered ten bushels; these thirtyfive bushels of peas fed two horses, two months, and left thirteen bushels for seed; the feed given the horses was a bushel basket three times a day, between the two. It was generally shook down and a little heaped, and upon threshing anrl measuring one of those feeds with my own hands, it was found to contain three quarts and one handful; with this they had a common allowance of fodder. While my horses were so fed, they were daily employed in the plough or hauling new rails in the wagon, and they were fat. We know that the common feer for work horses is at least eight quarts of corn per day; nearly twice as much as mine get when fed on peas. 
From the 25th to the 26th of May, inclusive, I planted peas in sixteen acres of corn, with the first ploughing, dropping them in the furrow next the corn. This corn was never worked again until it was tasseling; it was then ploughed and hoed and laid by; on one row across the field, there was no peas planted, and on the adjoining row, they were planted on both sides; when the corn was dry, I took two gentlemen in the field and directed their attention to this experiment, they were of the opinion that the row which had no peas could scarcely be discerned to be any way inferior to those which had them but on one side, while that which had them on both sides was much inferior to both of the others.

Between the 20th and 25th of September, these vines vere pulled up, and, after being three times wet, were at the expiration of fourteen days hauled up; the product was twenty loads of a twohorse wagon, as much as two horses could well pull. I fed two horses on them four months; and three milch cows and their calves, and four sheep, four months, once per day; the horses had them three times a day, a bushel basket to each, at each feed, with two bundles of fodder; the cows' feed was one basket to each; the calves,' one for the three, and the sheep one. While my horses were so fed, they were in almost daily use, a good deal of the time hauling wood; and the stable was a shed entirely open on the north and east sides; notwithstanding this usage and exposure they fattened and remained so.

The three cows while fed on these vines, yielded four gallons of milk per day, and from the two which had young calves, one half of the milk only was taken; in a word, when my cows have been fed on pea vines they have uniformly done well, and yielded an abundance of milk; and I have never had a cow stuck in mire; since $\mathrm{I}$ have been in this country. A neighbor of mine, two or three winters ago, fed four cows with young calves well, on turnips and short corn, and I fed two with a spring and a yearling calf, on pea vines and kitchen slops; and I made within one pound as much butter in the week, as he did; but I know we used more milk in our family than was used in his; and while the butter made from turnips has an unpleasant flavor, that made from pea vines will vie with any other (however made) for fineness, richness of color, and delicacy of flavor. And my horses have never been in better order, had a better skin, nor been healthier than when fed on peas or pea vines. 
I have been asked, are they not very harsh food, cured so late? If what has been just said does not satisfactorily answer that question, I will ask the following in turn: If calves of three or four months old will eat them heartily, and fatten on them, can they be fairly considered harsh food? I have again been asked, are they not difficult to cure, so late in the season? They are tedious, but not difficult, because they are not easily spoiled. Do they not also lose all their lcaves, when cured so late? They do lose nearly all; but this is made up over and over again, by the number of full and half grown peas they will have by remaining so late. Will not the fall peas in hauling up all shell out? They will shell very little if handled with tolerable care.

It has been alleged by some, as an excuse for not planting them, that they are weak handed, and cannot save the vines; but this is mere imagination, for it is well known, that a common hand will not strip more than one acre of corn blades per day; and I have repeatedly had two acres of pea vines pulled up by a plough boy, and the vines when cured, will weigh at least four times as much as the fodder, and will be as much more valuable.

I do not wish to be understood to recommend my manner of planting. It would, I am certain, be far more advantageous to plant them as soon as we have got our corn crop in, either in drill, on beds three feet apart, or cross the beds with a plough, three feet asunder, and drop from twelve to fifteen grains in a hill. The latter mode I would prefer on account of ploughing them both ways, which would entirely supersede the necessity of hoeing, whereby a larger field might be attended.

The first president of our Society, gives it as his opinion, that they would be an excellent preparatory crop for wheat. This has long been my opinion, (although I have not been yet able to make the experiment), and many years experience establishes this opinion with me, more firmly; and to place it almost beyond all doubt, it is the opinion of Judge Peters. Perhaps when they are intended as a preparatory crop for wheat, it would be best to sow them thick, in broadeast. There is no doubt of it in my mind, especially if the vines are turned in with a two horse plough, and the wheat immediately, or soon after, harrowed in and rolled. 
I should not have gone so much in detail upon the culture and use of peas, but I know that the prejudices against them are numerous and strong; and although I have already said so much, I must add one remark, which is this: while my neighbors' horses are eating corn, at least eight months in twelve, mine have never eaten it more than five; one year they eat corn three months, and this year but two, the balance of the year their food is peas, pea vines, and oats.

Some farmers are in favor of curing the vine in August, and contend that they are the more juicy; but if they do contain less juice in September, I think it then becomes more saccharine, is therefore thicker, and I should suppose would lose less in curing; we know that the juices of a corn stalk are much sweeter in September than in August.

As a further improvement in feeding of cattle, I would recommend that the shucks be well wet with brine, as they are stowed away in the fall. This was recommended to me last winter, and was done in this way: as many shucks were thrown in the house at a time, as would raise it six inches, after being well trod down; and as soon as they were sufficiently trod, the surface was well sprinkled with this brine; as many more were then put in, and the same process observed, until the whole were put away. In this way one bushel and a half of salt was applied to the shucks taken from these hundred bushels of corn, and the consequence was, my shucks were heartily eaten by my cattle, and until last winter, they never would eat them, as long as they could get pea vines. This is not all the advantage resulting from salting them; it was very evident that they were rendered much more nourishing, as the dry cattle which were fed on the shucks alone, were in nearly as good order as those which were fed on the vines. To do this properly, they should be made so wet as to heat and mould. The expense need not be counted at all, as cattle, while these shucks are given to them, will require no other salting.

As there is so little economy observed in fattening hogs in this part of the country, I beg leave to notice that also, and point out a better and cheaper mode. The common practice is to put them in a large pen and throw the corn on the ground; in a wet season, they are soon up to their knees in mire, and not a dry spot to lay on. In this situation there must be much corn 
wasted, and they cannot possibly thrive but very slowly. My practice has been to make two square pens adjoining; they are both floored with rails, and one of them is so covered as to turn the rain, and is well littered with leaves or straw, and fresh litter added at least once a week. In the other pen a trough is placed in which they are fed from twice to three times a day. One meal they are fed on peas, and the other two on corn; it is sometimes boiled and well salted, and at other times raw. This has been my practice for three winters; and my hogs have always fattened very fast and eat much less than those fed in the uncomfortable manner above deseribed.

Last winter, after killing off half of my fattening hogs, the others were fed altogether on fine corn meal, and although the weather had got much more serere, they fattened much faster than they had done before, and eat still less.

Last winter, when my fields were eat out, I commenced feeding my little stock of out hogs on corn; their allowance was six quarts; but when the weather became severe, they fell away fast on this allowance. I then laid the corn aside, and had four quarts of corn meal boiled every day, in ten gallons of water, until it boiled down to about eight; in this a half pint of salt was occasionally thrown while boiling; when done it was taken up in a large tub and given them the next day, and in one week from the day this practice was adopted, they looked much better, and from that time increased in flesh. When the spring opened, they were fed only three times a week, in the same manner, and in the month of May, rertuced to twice a week, and by the middle of Jnne it was discontinued. Had I persisted in giving them the six quarts of raw corn, I am satisfied more than half would not have seen the spring.

I have also adopted the prartice of orinding all my horse corn into fine meal, and find that I save a third after paying the toll.

I am, dear sir, with much respect,

Your obedient servant,

J. D. Gaillard.

J. T. Lewis, Esq.. Corresponding Secretary. 


\section{Furst Report of the Comnittee on Grasses and Grass}

LAANDS. PRESENTED AUGUST $13,1818$.

There is, perhaps, no branch of husbandry, of much nore importance to the farmer, than that on which it has become our duty to report, and we believe none is so much neglected in the Southern states; and if any require proof of this, we would invite their attention to our farm stock, and should they demand other evidence, we would remind them of the rise which beef and pork have taken within a few years.

Four years back, the highest price that could be obtained for pork was five dollars, and the beef that the country afforded was readily obtained at three cents, and three and a half per pound. From that time these articles have been gradually rising, and at this time, you pay six and a half cents for beef, and for two winters past the current price of pork has been from seven to eight cents.

This wretched state of things, owes its existence to two causes. The rapid decline of grasses in the forest, and inadequate crops arising from exhausted lands badly cultivated. How to restore fertility to our soil, and even to make it richer than ever it was by nature, we have been amply instructed by the able report presented by the committee on manures, at our last meeting; and it now remains for us to show, (if we caun) how the want of grasses for our stock may be supplied. In this attempt we will simply lay before you such facts as we have been enabled to collect on the subject.

Meadows, we are strongly inclined to think, are well calculated to ameliorate our condition; and almost every farmer who has a stream three feet wide, running through his farm, is in possession of more or less meadow land, which, while suffered to remain in a state of nature, answers no other purpose than to entrap our poor cattle in the spring of the year.

Experience has tanght all who have tried it, that to have a good meadow, it is only necessary to grub ont the under growth, 
and cut down and remove as many of the larger trees as will be necessary to admit the action of the sun. In some instances it is necessary to cut a small ditch round the edge of the meadow, so as to cut off springs; but in most cases, they become sufficiently dry after a few months exposure to the sun.

Ten or twelve years ago, a gentleman residing on the waters of Twenty-three Mile Creek, cleared a meadow of four acres at the head of a small branch, a great part of which was so high as to produce only what we call the broom or sedge grass; and on the low and wet parts, grew a coarse grass, very much resembling what we call the fox tail; but after this meadow had been mowed two or three years, these grasses became much finer, and yielded better and more abundant hay. For two or three years, the product of this meadow was not considerable, as it had been thickly covered with young maple, the sprouts of which were very troublesome for that time; but as soon as they were entirely subdued, so as to give the grass full possession of the soil, the quantity of hay was so much increased as to become an object of great importance, insomuch that the annual product for several years past, has been estimated at one hundred dollars, and the last summer seventeen large wagon loads of good hay was taken from it.

About ten years since, a gentleman residing on the Eighteen Mile Creek, cleared about one acre of meadow; which is in the winter and spring occasionally overflowed, and six years ago he cleared about two acres more, one of which he sowed with timothy, in October, putting one quart of seed on the acre. This meadow has been found to improve annually. The present year the acre of timothy produced four large wagon loads of hay, which made a stack eighteen feet in diameter at the base, and for six feet up this size was preserved, from thence it was gradually drawn in and terminated at a point fifteen feet from the ground. From the dimensions and solidity of this stack, we might safely estimate the wagon loads to average from eight to ten hundred weight. This meadow was viewed by one of the committee some days before it was mowed, and it was then so dry, that through the gieater part of it, the ground was very much cracked. Notwithstanding it must, from this appearance, have suffered much for the want of moisture, the timothy was generally four feet high, and close aromnd the roots of large stand- 
ing sweet gums which had not been deadened, it was as tall and looked as well as in any other part.

From the two acres of natural meadow, was taken eleven wagon loads of hay, which made two stacks, not much smaller than the one just described, and eighteen feet high; from the state that this meadow was in all the spring and summer, we must infer that if it had been properly watered the quantity of hay must have been greatly augmented; and in support of this inference, we will copy an article from an English author on Agriculture. Speaking of watering meadows, he says: "This is a part of husbandry strangely neglected in England, but of undoubted importance. I experienced it in my Suffolk farm, and yet stronger in my present Hartfordshire, where any person that may call on me may see the vast difference between a meadow in the parts watered and unwatered. I had this year, (1769) as much hay from off one watered acre, as all the other four unwatered ones in the same field."

The meadow on the Eighteen Mile Creek which produced the fifteen wagon loads of hay from three acres, is such land as our water courses abound with; it is a stiff soil, of very fine texture, one degree lighter in its nature than the common pipe clay. In summer, when the earth is neither parched with drought nor saturated with water, this soil has been profitably cultivated in Indian corn and oats; but in either of those seasons it is very difficult to tend, and produces but little. The foundation of this soil is a very stiff blue clay. The growth is maple, ash, sweet gum, white oak, some poplar and iron wood, and here and there on the high parts hickory and dogwood. This land properly drained, and thrown up into high ridges in the winter, with a two or four-horse plough, and an application of such manures as are adapted to cold stiff soils, might no doubt be profitably cultivated in corn and other grains: but it appears by nature to have been designed for meadows, and should never be appropriated to other use but where there is a surplus.

Among the grasses which grow spontaneously in these meadows, we notice a large coarse grass, very well known by the name of the red grass-this is generally found in smaller quantities than the other kinds, which may be owing to the others being earlier and thereby getting possession of the soil. This grass delights in water; but in very springy situations, that are al- 
ways cold and soft, it will not grow. Where it can be watered at pleasure and kept wet by any other means than the constant oozing cold springs, it yields much more abundantly than any other grass we are acquainted with; and when it has been frequently watered, the growth is so thick and tall as to require two acres to cure what grew on one; it makes a coarse but very sweet hay, of which cattle, sheep, and horses are very fond. It is the opinion of the most experienced and skilfull farmers that this grass is decidedly the most valuable we have either for mowing or grazing.

We might have noticed other meadows, as there are several others of value in our district, but we are not so well acquainted with their character. The two brought to your view afford the most abundant and incontestable evidence, that with a little labor and pains, we may have excellent meadows, not only of natural grasses but of timothy. In short, if these examples are not sufficient to excite others to go and do likewise, we despair of offering anything that will have that effect. With one more remark we will leave this subject. A meadow once established, is done for life or perhaps for a century.

Of exotics we can give but few examples, as but few experiments hare been made with them in our district.

The grass called dog foot or orchard grass, (dactylis glomerata) has been found valuable for grazing, which will appear by the following experiment. One of your committee some years back sowed a small lot with this grass, which came up too thin, the seed being bad; but notwithstanding this, he pastured it at all seasons of the year with cattle, horses, and sheep for ten or twelve years; he then cultivated the lot in corn, and some bunches of this grass was to be seen in it for some years after it had been thus cultivated. We may therefore presume that this grass, sown a proper thickness, in good strong ground, would be very durable and valuable for grazing.

Lucerne has been found hoth in England and this country very valuable for soiling. A gentleman of great respectability in our state, sowed a muarter of an arre. on a stiff red clay hill, with it (this was well manured) and in common years he has cut it seven times: but the last summer being unusually seasonable, it was cut nine times and kept six horses. 
This is considered in England a valuable grass for soiling, and although said to be an expensive one, is highly recommended by Mr. Young; by a fair calculation he makes it appear that the expense of planting and managing one acre is $4 l .9 s .2 d$; in this he includes manuring, ploughing. hoeing, mowing, and hauling home, and in this he has rent, tithes, and rates 1 . 10s., (which will not be found in the American account). He then says, keeping five horses from the beginning of May to the end of October, at $2 s .6 d$. per hear, per week, is $147.7 s .6 d$. which leaves a clear profit of $97.14 s .6 d$. It thus appears that with all the expenses attending its culture, it is found there to be a very profitable mode of feeding horses; but there it appears to be far more so, becanse there one acre kept but five horses during the season. here one quarter of an acre kept six horses.

The proper time for sowing is the latter end of March or beginning of April, because like the turnip it is subject to the ravages of the fly, and by early sowing it will attain a sufficient size so as not to be affected by the fly; if broadcast, twenty pounds of seed to the arre; if drilled in rows two feet apart, six pounds will be enough.

The value of lucerne crops are said to be much increased by sowing oats with them, in the proportion of six pecks of oats upon very rich land; two bushels on indifferent soils, and three for poor soils. As soon as the oats are sown and harrowed, the lucerne should be sown and a light harrow passed over it whether in drill or broadcast.

The land must be rich and kept clear of weeds to have a good crop; it flourishes, by the English account, best on deep rich friable loams, though it will thrive in any good dry soil, and in the coldest climate.

Mr. Young says, although this is considered an expensive plant to cultivate, if the value of the food be completed according to the maintenance of cattle per week, it will pay nearly cent per cent.

The Feather-grass, called by some white-top, (and which is said to be a Ditch grass known among them by the name of Weissen-heffer, ) has been tried in some parts of this district and in Georgia, and is found to answer well for winter and spring pasture for sheep and calves. This grass has been described by Dr. Anderson in his essays on agriculture as the 
Cock-tail or Feather-frass. (Stipapennata). On rich loams, and in the meadows near the mountains, this grass has produced fine crops of hay; but there the red clover and timothy being thought superior in similar situations, is taking the place of it, though they still think it a valuable grass for their lands of a second quality, which are chiefly pastured. With us it has been found to succeed best as a winter grass. It preserves its verdure in the severest weather, and grows vigorously during every relaxation of frost and very early in spring. If suffered to seed, it appears to die in June after the seed is perfected, but it puts out again in September, affording in its succulent juicy leaf, resembling the leaves of barley more than any other, a rich repast during the fall, winter, and spring months. As we recommend this grass chiefly for pasture, and it grows better than any other we know of, except ripple-grass or narrow leaved plantain, (plantago tenuifolia,) on poor stiff soils, it may be worthy of remark that our common crab-grass begins to grow, in our climate, just as the feather-grass declines, and as soon as the crab-grass dies, the feather-grass again succeeds it, and continues to afford good pasturage till the crab-grass appears the next year. Thus these two grasses will afford the desirable advantage of good pasturage all the year. 


\section{Report of the Commitee on Farm Stock.}

READ NOVEMBER 12, 1818.

The Committee appointed upon "Farm Stock," beg leave now to report:

That this subject embraces a very important branch of husbandry and rural economy, and is very extensive when taken in all its relations, must be obvious to all who have paid the smallest attention to agricultural pursuits. Your committee, believing that it was only intended by the Society that they should lay before it such facts and observations as were calculated to shew the preference of one species of the same genus of domestic animals over another, so far as it respected the operations of husbandry, or the comforts and profits of the farmer, will confine their observations to such as are considered of the first importance, and endeavor to shew why the farmer should turn his attention to the raising and using one kind rather than another. The breeds of horses not being so distinct in this country as in some others, it is difficult to describe the race most valuable to the farmer as best suited to the business of agriculture. In some of the middle states, the large dray breed is used as best suited to their heavy market wagons; and in the Eastern and all the Southern states, a middle sized horse is preferred, on account of his not consuming so much food, his being able to endure much more fatigue, and perform more work in the same time. Your committee are of opinion, that if horses are thought the most proper animal upon a farm, for the wagon, the plough, and the cart; those which spring from the common breed, and partaking a little of the blood-horse, are the best calculated to perform all the services of the farm horse, with the greater ease and expedition, and with the least expense to the owner. But those which are raised upon the farm, beyond what are necessary for its use, should, at any rate, be crossed with the best blood of the country, as such will not cost more, in the raising, than the coarsest, and will command a much greater price for the saddle or pleasure carriage. And if any particular breed of 
fine horses has shewn its decided superiority, in the Southern states, for vigor of constitution, activity and strength, it is that which has descended from the Genius* stock, which has, from its make and qualities, become almost a distinct race.

It has long been a question, however, whether the horse or the ox should be preferred as a beast of the plongh. It has been urged in favor of the ox, that he was capable of bearing great fatigue, was equally docile, lived nearly as long as the horse, subsisted upon less expensive foorl, and almost entirely without grain, and in the end was convertible into the most delicious food for man, and afforded valuable materials for his comfort and convenience. That if by accident he became lame or blind, still he wonld depreciate but little in his valne, whereas the horse, under the same circminstances, would be worse than nseless. To this it is answered, that although the horse is a more delicate and expensive animal, whose carcase is worth nothing, yet that he more than compensates for these qualities, by the expedition with which he performs his work, thereby enabling the farmer to save much time, by doing so much more in the same space, and "time is money." Although the ox does not require so much grain as the horse, yet he demands a greater quantity of provender or long forage, and as he is certainly less capable of bearing heat than the horse; it seems that he is only suited to an elevated and cool conntry, which affords good pasturage and meadows; and therefore, before the ox can be worked to great advantage in any country. grass and hay must be first attended to. For these reasons, where the ox was formerly the common beast of the plough, the horse is almost universally substituted. To find an animal uniting most of the good qualities of the horse and ox, with but few of the objections applicable to either, is certainly a great desideratum in agriculture. In the opinion of your committee, the mule is better calculated to answer the general purposes of the farm, than either the horse or the ox, as uniting the good properties of each with but few of the bad. Nothing but ignorance and prejudice conld have kept the value of this useful animal so long from being known among ns. But of what are ignorance and prejudice not ca-

* By reference to the Stud Book, it will appear that the imported horse which has given a name to this stock of horses, was Genius, and not Janus, a: is commonly supposed. 
pable? It is, however, rery strange, that the most intelligent writers upon farm stock, appear, and acknowledge themselves to be iguorant of them as a beast of the plough, particularly as their great value has been long known in the south of Europe, Africa. Asia, and South America. In old Spain, the stock, from which they descend, is as much attended to, in point of pedigree, as the finest horses in England-there a pair of good mules will cost twice as much as a pair of good horses, and in South America, a mule is considered worth many horses, and in some parts of our own state, one good mule is valued equal to two plough-horses. These facts are stated, to shew that we are not singular in thinking highly of mules, and for this preference it is thought there are reasons sufficient to convince every calculating mind. The mule is more easily raised than the horse, more able to bear heavy burthens, equally strong for the draft, more patient, equally docile, will live twice or thrice as long, capable of enduring much more labor, will do as much work in the same time, and will not be more than one half the expense, as they will not eat more than one half the grain, will make use of long forage, which the delicacy of the horse will reject, and will bear the heat full as well, perhaps better. Besides all this, they are able to work sooner, and are only in their prime when the horse has become a useless expense by age. From the smallness of their foot, they may not answer so well as the horse in deep, miry roads, but from the excellence of the hoof, they will never require to be shod, except upon long journies orer rocky roads.

That most useful and neglected animal the cow, has engaged the attention of your committee, and as this is believed, upon the whole, the most important stock for the farmer, much might be said upon this subject, but it is thought unnecessary, upon the present occasion, to say more than to express an opinion, which kind is the best for the country, and the reasons for that opinion. That the stock which is mingled with what is called in this country, the English breed, and in England the short horned or Dutch breed, is better than the common stock of the country, it is believed, no one can doubt, who was present at the cattle show in September last, of this Society. or who has, at all, attended to the improvement of this animal. There sevcral calves were exhibited, all of which except one, partook in 
different degrees, of this foreign breed of cattle. The one exhibited of the common breed, was certainly very large, and did great credit to its owner, and at the same time no one present could think that it was at all comparable to any one of the others. This was conclusive as to appearance, and if they are not more tender or difficult to keep than the common breed, they must be better. Those of the committee who have had the opportunity of judging from experience, upon this subject, think them not more difficult to keep; but on the contrary, think that they will look better, grow much larger, and take fat much sooner upon the same pasture. This observation relates to enclosed pastures, and they would not be understood to say, that this breed of cattle requires no more food than the common; but, on the contrary, they believe that cattle of all kinds require the quantity of their food to be in proportion to their size. Although this breed of cattle is thought more tender than others, in England, yet from its superior excellence, it has been increased in most parts of that country. Notwithstanding cows of this race give much more milk than those of the common, yet much of their excellence does not arise from this circumstance, as they can only yield in proportion to the food which they consume. Their superiority arises almost entirely from their size, the smallness of their bone, in proportion to their flesh, their inclination to take fat earlier, and to make fat upon the best parts. This inclination to take fat earlier, and to make it upon the best parts, is attributed by the most experienced breeders to the beauty of their form; and they are governed in their selection of stock, to breed from, not so much by the size as by the smallness of the bone; and the beauty and symmetry of the form. It is much to be regretted, that this valuable animal, which contributes more largely to the comfortable subsistence of man than any other, is so much neglected in our country, and left to bear every wind and rain which descends from heaven, without a shelter, and with no better allowance than straw or husks. If the farmer, instead of keeping a large stock of impoverished cattle which tend to impoverish him, and which can yield nothing to his comfort or his profit, would keep fewer, which would enable him to keep them better, he wonld, for all his additional kindness and attention, receive ample returns, in a rich variety of delicious beef, milk, butter and cheese. 
However valuable and important a small stock of sheep must be to every farmer, for food and clothing, yet an extensive flock is not so valuable as in some other countries, where the carcase is in great demand, and the fleece commands a ready sale. But it is very desirable that every one who keeps sheep, should have the kind most useful for him, and suitable to his local situation. Some years ago, it was thought that wool of the finest kind, would be an article of the first importance in this country, and many men in our country were merino mad. But the bubble has bursted, and many have learned, by experience, that this was a delusion, and now know, that a flock of sheep larger than is necessary for domestic consumption, is a useless expense. But this delusion of the day has been of great importance to the country, in causing much more attention to be bestowed upon this valuable domestic animal. It is believed that a mixture of the merino blood improves our native sheep both in the carcase and fleece. All crosses of this breed, make the stock retain its wool much better. We know but little of other breeds in this country; but perhaps if we could get the Bakewell or Dishly breed, which is so remarkable for its size and inclination to take fat, it would make a valuable acquisition to our farm stock.

As to hogs, poultry, \&c. your committee having but little information, and fearing that they have already trespassed too long upon your patience, and said nothing which may afford a useful hint to any one, beg leave to be silent.

November 12, 1818.

\section{Second Report of the Committee on Manures.}

JULy MEETing, 1819.

The Committee on Manures, in continuation of the report submitted to the Society in July last, having therein treated of three divisions of their subject, animal, vegetable, and compound manures, proceed to the consideration of the fourth division, fossil manures; and will conclude with some observations relative to the time and mode of application of manures, to the soil.

Your committee are not acquainted with any fossils to be found in this district, which in their natural state have been used as manures, but they are inclined to believe that marl, or some earth resembling marl in its effects may be found. It 
is believed we have neither gypsum or linestone, but at the same time proper searches have not been made. It is here recommended to offer a handsome premium for the discovery of any substances, which actual experiment may prove to be beneficial. A judicious mixture of soils of different qualities, would doubtless be of great service. A tenacious clay is opened by the application of sand and a porous open soil, is improved by the addition of clay; but the labor of this admixture would be very great, and the fertility communicated to the soil, not equal to our ideas of improvement by a system of manures. Gypsum may be procured at a high price, and some few experiments have been made with it, but they have not succeeded, though it is probable the plaster had lost most of its good qualities, from having been ground for a long time. But your committee know that it has produced no effect, when applied to young corn in the hill, or to young clover and grass on very poor stiff soil, neither was the soil benefited for a succeeding crop, as sometimes occurs with this fossil. Notwithstanding these discouraging circumstances, such have been the advantages in other places, resulting from the use of gypsum, that your committee recommend to every member, to lose no opportunity of procuring a little of it and apply it to various crops, in various ways. A thin layer of it, mixed in turn with a compost heap, especially where a great proportion of vegetable matter is used, would undoubtedly tend to break down the woody fibre, and reduce the mass more speedily to the state of good manure; and in all operations with gypsum it should be recollected, that it is now pretty well ascertained, that it is not in any great degree a manure of itself, but that the vitriolic acid, converting vegetable substances into manure, is the cause of its imparting fertility to soils; where there is no such vegetable substance, it must be useless. Until, however, the wisdom of our Legislature, aided by the public spirit of our citizens, shall open our rivers or improve our roads, your committee despair of seeing gypsum generally used for agricultural purposes, even if its effects were as decidedly advantageous here, as they have been found to be in our sister States. They therefore proceed to bring to the notice of the Society, another substance, which has the all important advantage of being in the greatest abundance, and which has lately been highly recommended by zealous and intelligent writers. 
This substance is burnt clay. Sir John Sinclair, in a late work on agriculture, published only last year, informs us that he found the first account of clay ashes, in an agricultural work, published in the year 1732, so that it is an old practice lately revived, and which has been highly recommended by the most voluminous writer of the age, Mr. William Cobbett, who, from his own experience, recommends it in the strongest manner for his Russian Turnip. The author of the "Complete Grazier" also gives an account of clay ashes; and says that poor worn soils, which, with manure, would only produce rye, with ten or twelve loads of clay ashes, have produced abundant and luxuriant crops. Mr. L'Hommedieu also recommends clay ashes to the New York Society for the Promotion of Agriculture, as the cheapest manure that can be procured; and lastly, Dr. Mease, in a letter to the Philadelphia Agricultural Society, published last year, collects and cites many authorities, tending to prove the usefulness and cheapness of clay ashes, as a manure. The weight and respectability of these authorities, have decided your committee to commence some experiments on this subject, as soon as our harvest is secured, and to recommend to their brother farmers to multiply the chances of success, by burning clay into ashes themselves.

Although your committee do not understand the precise mode in which burnt clay fertilizes the soil, further than by opening and pulverizing it; yet the results of combustion are, in many cases, so little known, that they will not suffer their ignorance of the modus operandi, to check their endeavors to obtain useful and practical knowledge; and they are the more incited to spare no exertions on this subject, from the conviction, that if the clay ashes do really fertilize a stiff, worn soil, they will furnish the great desideratum of our farmers, namely, a sufficiency of manure. For not only are the materials, clay and wood every where at hand, but it is believed the labor of preparing the ashes for the soil is less than in any other mode of procuring manure in any quantity. Your committee will now proceed to detail the mode they would recommend for obtaining the largest quantity of these ashes, with the least labor.

On some clay ridge most convenient to the field intended to be manured, dig a hole one foot deep, and from ten to fifteen feet square. Small kilns are recommended to begin with, as exper- 
ience will suggest remedies for defects. Place the excavated clay around the sides of this shallow pit, and in the centre of it construct a small square pen, four or five feet high, and nearly a foot square, with small kindling wood, similar to the top of a common clay chimney; then cut a cord of wood four feet long, and lay the sticks crossing each other, over the bottom of the pit; having previously made a channel from the bottom of the small square, to the outside, by laying two stout sticks, eight or ten inches apart, on the ground, and covering them with flat rock or turf sods, to communicate a current of air to the centre and keep up the fire. This channel will not be needed after the kiln is once fairly on fire; then cover over the whole surface of your kiln with turf sods from the locks of your fence, and throw on the clay you have excavated, and dug from about it, covering the sods two or three feet with it; then set fire to your kiln, and cover the top of your small square pen with brush and sods, to exclude external air, which should only be admitted from the channel outside. It is there to be treated like a coal kiln. As the clay burns, more is to be thrown on in the places most burnt; and as the clay will burn of itself, you must supply more till you have enough for your purpose. The only precaution necessary is, not to let the fire break out, till you have enough burnt, and this may involve the necessity of watching it at night. As soon as the ashes are cool, they are fit for use, and should be spread on the land, and lightly ploughed or harrowed in, where it is said, they will have an astonishing effect in producing prodigious crops of grass, grain, or any vegetable.

Your committee will conclude this part of their subject, by stating distinctly, that the information here given is derivative, and their authorities have been cited. They are sorry that their own experience furnishes nothing on the subject; but they will add, they are sanguine as to the results, and hope that the members of this Society will zealously unite in the determination practically to prove the utility of clay ashes on grain and turnips.

The application of manures to the soil, which is the remaining subject of discussion, should vary according to the nature both of the manure, the soil, and the crop which is first to be benefited by it. All ameliorating mixtures of soil may be made at the most convenient season, but the application of manure 
must be considered, both as to the state of the manure itself, (which involves the controversy between hot and short muck farmers), and as to the state or preparation of the land, for a crop, or during its growth. With regard to the state of the manure at the time of application, justly celebrated farmers have given opinions diametrically opposite; and yet your committee are bold enough to disagree with both opinions considered as exclusive, and to say that both fermented and unfermented manures are proper at different times, and for different crops. For instance, your committee would not recommend the immediate application of hot stable manure, to a crop of wheat, though they would have no objection to a corn or pea crop; and the reason is obvious: Not only might hot stable manure produce diseases in a wheat crop, but it would probably introduce the seeds of weeds, which would have an opportunity of again seeding themselves and polluting your land, before your broadcast crop is off; but in a corn crop we should not fear these unhappy consequences, because our corn is a stout and vigorous plant, requiring strong manures; and as it is always a drill crop, the young weeds which might be introduced with the unfermented manure, would be destroyed in the necessary culture of the crop. These instances will enable the Society to decide for themselves, when fermented or unfermented manures should be used. Well fermented manures and composts should in general be applied for broadcast crops, except perhaps barley; and hot muck may in this country be safely applied to all drill crops.

Although your committee have stated that short muck or fermented manures or composts, are a proper dressing for wheat, and for the reasons they have given, yet they do not wish to be understood as forbidding altogether the application of unfermented manures to that crop. On the contrary, they would recommend experiments, on a small scale, of stable manure, to the wheat field, in order to ascertain more precisely its nature and effects. To this they are the more induced, from having lately seen a successful experiment made with hot muck on wheat, in the fourth volume of the memoirs of the Philadelphia Agricultural Society. Comparative experiments are not sufficiently attended fo, and although it is now known that fermented manures are proper for the wheat field, yet sufficient trials have not been made with hot muck to prove that it may not have advantages, 
outweighing the disadvantages of introducing weed seeds, and perhaps some diseases. For weeds ought not to be dreaded so much in this country, as in others, on account of the frequency of fallow crops; and perhaps the disease, introduced by hot muck, may be attributed to want of judgment in the farmer, in applying it in too great a quantity. If the evil of weed seeds and disease can be remedied or even abated, your committee see a great advantage in the superior strength and quality of hot muck, as they believe that twenty cart loads of it will impart as much fertility to an acre of clay land, as forty of well rotted manure; because the former would contain nearly as much matter as the latter, and of greater strength, and have besides all the grasses in them, which rotted manure will have lost in the different stages of its decomposition.

With regard to the time of applying manures to the soil, by attending to the principles laid down in the first part of this report, we shall be enabled to decide that question with greatest probability of successful result. As carbonic acid and ammoniacal gases are formed during fermentation, and these are powerful agents for our purpose, it follows that these gases should be formed in the soil, where they would immediately benefit us, and not in a manure heap, whence they would escape us, in the surrounding atmosphere, and be lost. Further, as all manures must be in a dry state of solution before they can become the food of plants, it follows that manures should be kept dry, till applied to the soil, both to check fermentation, and the consequent escape of gases, and to preserve their soluble parts from being dissolved and wasted in the manure heap. From these two principles, it results that hot muck should be kept in or under your stable as compost and dry as possible, or if in a manure heap, it should be well covered with earth, till you are about to plant your drill crop; previously to which, it should be carted on the land, spread on the surface evenly, or scattered in drill in deep furrows, and covered with the plough without one moment's unnecessary delay. The carting and ploughing in, should be done at the same time if possible.

Vegetable composts, having an excess of fibrous and insoluble matters, should be treated differently. To break down and dissolve the woody fibre, the vegetable substance composing your compost should be laid in layers, intermixed with lime, ashes, 
gypsum, clay ashes, or animal dung, and water enough to commence a fermentation should be added, and when the carbonic acid gas begins to fly off, the heap should be well covered with earth, and kept so till wanted for your broadcast crop. The carting out, spreading, and ploughing under, should be performed as expeditiously as possible, and this operation in both kinds of manure should be performed as immediately before the seeding as convenient, in order that your young plants should lose none of the benefits to be derived from them.

There are two points which present themselves here, which though not strictly belonging to this committee, they will briefly examine. One, the most advantageous mode of spreading manure, whether all manures had not better be applied to a crop preparatory to wheat, rather than to the wheat crop itself.

When manure is to be applied to a drill crop, which is to be succeeded by one or more drill crops, your committee are of opinion that scattering the manure along the bottom of furrows, four, five, or six feet apart, is the best mode, because, one-half of the quantity at least, will be sufficient, or saved for other fields. Your manure is better beneath the soil, and of course more secure from evaporation, the operation itself is more easy than flush ploughing under, and if three drill crops are taken, by running your drill finrrows in different places each year, they will probably all be good, and your field will at least be all manured by one or two cross ploughings. Unquestionably these reasons do not apply to a broadcast crop, where the manure should be spread as regularly as possible, all over the surface, and as regularly ploughed under.

With respect to the application of my manure, immediately to a wheat crop, your committee are of opinion it ought to be avoided if possible, at least until further experiment shall test the degree of danger to be incurred from disease on weeds. One bold farmer, as above mentioned, has been successful in one attempt at raising a heavy crop of wheat with stable manure, but one fact should not be permitted, hastily, to overset the experience of years. A reasonable prudence will warn us that the greatest care will not secure our young wheat from being overrun with weeds in the spring, which will not only injure the crop, but the land afterwards, even if the grain escapes the diseases to which the immediate application of hot stable manure 
exposes it. In all stiff soils, it is certainly advisable to plant a drill crop, as a preparation for wheat, and apply your manure to that crop. Weeds will then be destroyed in the cultivation of this crop, and your land in the fall will be left clean, pulverized, and rich. Potatoes, beans, peas, to be cut for fodder, or any drill crop which may be removed by the last of August, would repay the farmer for his additional trouble.

Your committee will conclude at this time, with the following general rules with respect to manures, and their application, which, though they may be liable to some exceptions, they trust will prove useful.

Farm-yard manures should be kept from fermenting as much as possible. This process should take place in the soil.

In composts, fermentation should be encouraged so far as to break down the woody fibre of the vegetable substances of which they are composed, so as to render them soluble, and afterwards kept dry and cool.

The time of application to the soil, should be that immediately preceding the introduction of the seed.

All which is respectfully submitted.

Thomas Pinckner, Jr.

Chairman. 


\section{ON Ripple Grass.}

\section{BY THOMAS PINCKNEY, JR., July 1819.}

Altamont, July 7, 1819.

SIR-Permit me to recommend to the attention of the Society, a small grass growing spontaneously all over our district, and which has the important advantages of being a native of our clime and soil, and retaining its verdure and juices throughout the winter. I allude to the narrow-leaved plantain, or ripple grass, (plantago tennifolia). My sheep have never thriven well in winter, notwithstanding they have a dry fold; a good shelter, with racks and troughs, and are tolerably well supplied with dry food and pea hay; but last winter they suffered so much irom the want of pasture, and brought me so few lambs, that my attention was naturally turned to the best mode of procuring inem green food, occasionally during the winter, and very early in the spring. A visit which I paid to a neighbor, solved my difficulicy. His sheep were in fine order, and he had not lost a lamb. A small part of his apple orchard, not half an acre, was tolerably well set with ripple grass, and the ewes and young lambs were turned on it. As I know that in all other respects, my flock are at least as well treated as his, I could impute his success to no other cause than his ripple grass; which was his opinion also. Thinking well of this grass, I had collected and sown a few seed near my house, mixed with orchard grass and red clover; and I think it has always maintained a superiority over them, as a winter bite for sheep. The soil is exceedingly poor, a stiff, red clay and very stony. I find this grass very favorably spoken of in Anderson's Essay on Agriculture, who says, that "it deserves the attention of the farmer, as a valuable pasture grass. It will thrive upon barren soils, where hardly any other plant could live. It may most easily be distinguished on poor clays, where it is frequently found without the mixture of any other plant; cattle, horses and sheep, eat the leaves greedily, especially sheep, which bite it very close to the ground."

This authority so strongly confirming my own observation, has induced me at this time to trouble the Society with these remarks, as the seed of this grass is now ripe, and to recommend to my brother farmers, to collect it carefully, and to sow it in September, on a piece of good land, well ploughed, and the seeds 
harrowed in. I would not advise the mixture of any other seed with it, unless they can procure that of the broad-leaved plantain, which also grows commonly about our fields; but I would recommend them to give it a fair chance of success. Not to rely on its growing on poor land; but to prepare half an acre by deep ploughing, and manure, if the piece is not naturally rich, to sow his seed thick enough, and harrow it in carefully. This little trouble will be nothing in comparison of its value to him next winter, and if he but performs his part well, I feel assured he will soon extend his half acre to the quantity his flock will require.

$$
\text { I am sir, }
$$

Your obedient humble servant,

Thomas Pinckney, JR.

Joseph V. Shanklin, Esq. 


\section{Address to the Farmers of Pendleton District.}

September 8, 1819.

The committee appointed by the Farmers' Society at the August meeting, beg leave to report the following address, to the inhabitants of this District, as a preface to the queries, proposed to be published; and they recommend that the Committee on Publications be directed to cause the Address and Queries to be inserted in the Pendleton Messenger.

To the Farmers of Pendleton District:

The Pendleton Farmers' Society has been organized since the year 1815; and perhaps they have been remiss, in not stating, publicly, before this time, the objects of their institution, and the means by which they hope for success.

The great object of this Society is the agricultural improvement of the district, by directing the attention of their brother farmers to the various branches of rural economy, and by the.introduction of the most modern and approved system of husbandry; and surely it is obvious to all, that such improvement is necessary to our welfare and prosperity. We are the largest, and it is believed, the most populous district in the State; but our importance is reduced by a want of information on many essential points, and particularly on agricultural subjects. Our fellow citizens elsewhere, are making rapid advances in the arts which improve and adorn society; the spirit of internal improvement is awake and active; science flourishes, and all classes of our countrymen are vieing with each other in efforts to raise our national character, both at home and abroad. And shall we be backward on such an occasion? Shall we be the only idlers in a contest for the prosperity of our country? Shall we be the drones to devour the labors and the talents of industry and skill? We trust you have too much virtue, too much zeal, and too much patriotism to suffer such an imputation to be cast upon you.

Although our lot has been cast in a remote corner of the State, among rugged mountains, with a vast proportion of our soil unfit for cultivation, and what is worse, without a convenient convey- 
ance to market, yet we have here many advantages and blessings to be thankful for. Our district is among the most healthy in the Union-our land is cheap; and a sufficiency of it of tolerable quality, is within the reach of every intelligent and industrious farmer. If we make less money, we have less need of it here than elsewhere-a little judgment and a little industry will procure from our fields and our flocks all the requisites for hmman comfort. Foreign luxuries ought to be abandoned*-There is hardly an article among them which had not better be relinquished. Let us all unite with zeal and activity to increase the solid comforts of home.

To promote these praiseworthy objects, to increase the real comfort and happiness of every farmer in the district, and to make him respectable and independent, the Farmers' Society was instituted. The Legislature of the State, perceiving the happy consequences likely to result from their exertions, granted them an act of incorporation in the year 181\%. They have since acquired a little property, and as it may with truth be said their object is to be useful, will not their brother farmers in the district unite with them in promoting such an object. The effect of combination is great; a few individuals, however zealous, can do nothing; but a society composed of members from all parts of the district, can, and will be useful in the highest degree. Much good has already been effected, many instances of which are on the records of the Society. The annual contribution of each member is a mere trifle, but the aggregate of contributions would enable the Society to extend their means of information and usefulness. Practical books, good ploughs, harrows, and other implements of husbandry, and good seeds of various kinds, would be purchased. Larger premiums could be given; and it is hoped that the day is not distant, when annual fairs shall be established at our anniversary, to which all the farmers of the district may resort, for the sale or purchase of fine animals, fine samples of grain, or the products of the loom, the workshop, the dairy or the orchard.

The views and objects of the Society having been thus fairly

\footnotetext{
* Many good substltutes for Coffee may be found. Rye well cleaned, washed, and dried in the sun, then parched and ground, makes a beverage hardly to he distingulshed from coffee, and more wholesnme. Carrots cut in very small squares, drifd hard in the sun and then parched and ground, is another good and wholesome substitute.
} 
and candidly stated, the farmers of the district are invited to become members. There is hardly a man who can not give information on some point, and if we all contribute what we know, we shall obtain a mass of information which must be useful. It is not essential that those living at a distance should attend every meeting, though as punctual an attendance as circumstances will permit is much to be desired. The Society already consists of eighty members, and new members are admitted at every meeting.

As it may be inconvenient for some farmers to become members of the Society, who are yet desirous of assisting it in so good a cause, by all the means in their power, they are respectfully requested to communicate any information they possess, addressed to Joseph V. Shanklin, Esq., our corresponding secretary. The Society know that practical farmers are not literary men; the style or manner of communication is perfectly immaterial; and the Society, as a body of plain farmers themselves, want plain facts, in plain language. They therefore hope that practical farmers will write to them, and lest any one may suppose the information he has to give may not be on a subject of sufficient consequence, they have directed a list of questions on the most important subjects to be added to this address. This mode, it is hoped, will encourage farmers to write, as they have nothing to do but to answer a plain question; and the example once set will be followed by others.

\section{QUERIES.}

Manures.-Have you made any experiments with manures? Of what nature were they? Have you ever used fresh stable manure? What is the difference, in point of strength, between it and rotted dung? In what quantity, to what soils, in what manner, at what time, and to what crops have you applied it? To what crops with the greatest success? Have you ever made a compost heap, viz. a heap consisting of dung, earth and vegetable matter, such as weeds? In what proportion did you use each of these materials? What is the best method of making and collecting the greatest quantity of manure even on a farm? Have you ever hauled any creek mud, or other stuff from ponds or branches, on your fields, or to your manure heap; and with what benefit? What is the nature of the soil to which you applied this manure? Have you ever used ashes as a manure? Were they 
leached or unleached? What is the difference in value between these as manures? To what soils were they used, and with what effect? Do you not think unleached ashes more beneficial when mixed in the compost heap? Have you ever applied lime to your land? Do you know any thing of marl in your neighborhood? It is a whitish, clayey earth, and will effervesce when vinegar is poured on it.

Soils.-Of what nature is the soil upon which your experiments have been made? Is it sandy or clayey or loamy? What particular grains or grasses have you found best adapted to particular soils? Is there any substance in your soil unfriendly to any particular vegetable or plant, and how have you or can you colrect it?

Tillage.-How deep ought lands to be ploughed? Should the black mould or top earth only be turned up, or onght the yellow or red earth underneath to be turned up also? In what proportions ought they to be mixed? What is your method of destroying weeds and grass in your fields? Do you fallow your land? Do you perform this operation in winter and summer? Are your fallows naked, or otherwise? Do you lay your fields in ridges or lands? How wide are the latter? What is the best method of preparing land for the reception of seed, particularly for wheat? When do you haul your manure on the land? Do you spread or drill it?

Stock:-Are not oxen more profitable than horses? What is the difference of lieep and work between a pair of horses and a yoke of oxen? Do you use mules? Are they better than horses? In what respects? Have you ever used large wooden hames for horses? Do you prefer them to collars? Do oxen draw best with the collar or the yoke? Did you ever yoke them by the horses? Was the yoke placed in the front or back of the horns? How can you improve the breed of sheep, as respects the quantity and quality of wool and mutton? How, and upon what, do you maintain your ewes and lambs, in the winter and spring? Is it profitable to shear lambs the first of the year? Do you shear your sheep once or twice a year? What are their disorders, and what remedy have you for them? What is the best method of raising calves? What is the best method of fattening cattle? How best kept for the pail? What is the best method of making cheese and butter? Do you know the disorder in cattle called 
milk sick? Do you know any cure for it? What occasions the hollow horn? How is it most easily and effectually cured? How do you raise hogs? What breeds are the best? Which is the cheapest and the best mode of preparing them for the knife?

Grain.-Which is the most productive species of wheat; the red, white, yellow bearded, or naked? Is winter better than summer wheat? In what proportion? What are the causes of smut, blast and mildew? How are these prevented or remedied? What is the best method of preserving wheat between harvest and threshing time? And between threshing time and grinding? Is rye a profitable crop with you? How do you cultivate oats? Are they worth cultivating? What species have you found most productive? Do our soil and climate suit barley? What is the greatest quantity of this grain that you know of having been made to an acre? How do you cultivate Indian corn? In what manner is the ground best prepared for it? How should it be manured and tended? In what manner and to what extent can beans and peas be cultivated? What is the best time for cutting up the vines? How best cured? What is the greatest weight of peas and cured pea-vines that you have obtained from an acre? Grasses.-What grasses make the best pasture? What the best hay? What facts have you relative to the culture and value of lucerne, St. Foin timothy, and clover, feather grass or white top, and orchard-grass? Can not some of our native grasses be greatly improved by culture? What sort of pasture agrees best with sheep, meat cattle, horses and swine? What particular directions can you give on the subject of grazing? Are you acquainted with the narrow-leaf plantain? Do you esteem it as a pasture grass?

Fruit Trees.-What kind of apples afford the best cider? Which is the best method of grafting, inoculating, and planting of orchards? In what manner do you cultivate peach, plum, nectarine, apricot, quince, and cherry trees? Will nectarine trees, not grafted, ripen their fruit? May not the fig be successfully introduced into the district? 
Vermin.-How do you destroy moles? Will palma christi drive them away? How are grubs in your corn and flax destroyed? Which is the best method of getting rid of the bugs that destroy your melon, cucumber, and pumpkin vines? How do you destroy the canker worms and caterpillars that infest orchards? How can you overcome the lice and flies which so greatly injure cabbages and turnips?

Bees.-Have you any improvement in the management of bees? 





